\title{
Climatology and long-term evolution of ozone and carbon monoxide in the upper troposphere-lower stratosphere (UTLS) at northern midlatitudes, as seen by IAGOS from 1995 to 2013
}

\author{
Yann Cohen ${ }^{1,2}$, Hervé Petetin ${ }^{1}$, Valérie Thouret ${ }^{1}$, Virginie Marécal ${ }^{2}$, Béatrice Josse ${ }^{2}$, Hannah Clark ${ }^{1}$, \\ Bastien Sauvage $^{1}$, Alain Fontaine ${ }^{1}$, Gilles Athier ${ }^{1}$, Romain Blot $^{1}$, Damien Boulanger ${ }^{3}$, Jean-Marc Cousin ${ }^{1}$, and \\ Philippe Nédélec ${ }^{1}$ \\ ${ }^{1}$ Laboratoire d'Aérologie, Université de Toulouse, CNRS, UPS, France \\ ${ }^{2}$ Centre National de Recherches Météorologiques, CNRS-Météo-France, UMR 3589, Toulouse, France \\ ${ }^{3}$ Observatoire Midi-Pyrénées, Toulouse, France
}

Correspondence: Yann Cohen (yann.cohen@aero.obs-mip.fr)

Received: 21 August 2017 - Discussion started: 19 September 2017

Revised: 2 February 2018 - Accepted: 16 March 2018 - Published: 20 April 2018

\begin{abstract}
In situ measurements in the upper tropospherelower stratosphere (UTLS) have been performed in the framework of the European research infrastructure IAGOS (In-service Aircraft for a Global Observing System) for ozone since 1994 and for carbon monoxide (CO) since 2002. The flight tracks cover a wide range of longitudes in the northern extratropics, extending from the North American western coast $\left(125^{\circ} \mathrm{W}\right)$ to the eastern Asian coast $\left(135^{\circ} \mathrm{E}\right)$ and more recently over the northern Pacific Ocean. Several tropical regions are also sampled frequently, such as the Brazilian coast, central and southern Africa, southeastern Asia, and the western half of the Maritime Continent. As a result, a new set of climatologies for $\mathrm{O}_{3}$ (August 1994December 2013) and CO (December 2001-December 2013) in the upper troposphere (UT), tropopause layer, and lower stratosphere (LS) are made available, including gridded horizontal distributions on a semi-global scale and seasonal cycles over eight well-sampled regions of interest in the northern extratropics. The seasonal cycles generally show a summertime maximum in $\mathrm{O}_{3}$ and a springtime maximum in $\mathrm{CO}$ in the UT, in contrast to the systematic springtime maximum in $\mathrm{O}_{3}$ and the quasi-absence of a seasonal cycle of $\mathrm{CO}$ in the LS. This study highlights some regional variabilities in the UT, notably (i) a west-east difference of $\mathrm{O}_{3}$ in boreal summer with up to $15 \mathrm{ppb}$ more $\mathrm{O}_{3}$ over central Russia compared with northeast America, (ii) a systematic west-east gradient of $\mathrm{CO}$ from 60 to $140^{\circ} \mathrm{E}$, especially noticeable in spring and summer with about $5 \mathrm{ppb}$ by 10 degrees longitude, (iii) a
\end{abstract}

broad spring/summer maximum of $\mathrm{CO}$ over northeast Asia, and (iv) a spring maximum of $\mathrm{O}_{3}$ over western North America. Thanks to almost 20 years of $\mathrm{O}_{3}$ and 12 years of $\mathrm{CO}$ measurements, the IAGOS database is a unique data set to derive trends in the UTLS at northern midlatitudes. Trends in $\mathrm{O}_{3}$ in the UT are positive and statistically significant in most regions, ranging from +0.25 to $+0.45 \mathrm{ppb} \mathrm{yr}^{-1}$, characterized by the significant increase in the lowest values of the distribution. No significant trends of $\mathrm{O}_{3}$ are detected in the LS. Trends of CO in the UT, tropopause, and LS are almost all negative and statistically significant. The estimated slopes range from -1.37 to $-0.59 \mathrm{ppb} \mathrm{yr}^{-1}$, with a nearly homogeneous decrease in the lowest values of the monthly distribution (5th percentile) contrasting with the high interregional variability in the decrease in the highest values (95th percentile).

\section{Introduction}

Ozone plays an important role in the thermal structure of the stratosphere and in the oxidizing capacity of the troposphere as a major source of hydroxyl radicals $(\mathrm{OH})$. Tropospheric ozone is also a strong greenhouse gas (IPCC, 2013, AR5). In contrast with carbon dioxide $\left(\mathrm{CO}_{2}\right)$ and methane $\left(\mathrm{CH}_{4}\right)$, the scientific understanding concerning its radiative forcing is still at a medium level. Nevertheless, its impact on sur- 
face temperature has been shown to reach its maximum when changes in $\mathrm{O}_{3}$ mixing ratios occur in the upper tropospherelower stratosphere (UTLS) region (e.g. Riese et al., 2012). Carbon monoxide (CO) is a precursor for $\mathrm{CO}_{2}$ and tropospheric $\mathrm{O}_{3}$. It is also a major sink for $\mathrm{OH}$ radicals in an unpolluted atmosphere (Logan et al., 1981; Lelieveld et al., 2016), thus increasing the lifetime of $\mathrm{CH}_{4}$, such that $\mathrm{CO}$ emissions are considered "virtually certain" to cause positive radiative forcing (IPCC, 2013, AR5). Because of its $\sim 2$ month lifetime (Edwards et al., 2004), it can be used as a tracer of combustion processes, mainly anthropogenic emissions and biomass burning (Granier et al., 2011), although it is also a product of the oxidation of $\mathrm{CH}_{4}$ and isoprene $\left(\mathrm{C}_{6} \mathrm{H}_{8}\right)$. Identifying the contributions from different factors to $\mathrm{O}_{3}$ concentrations in the UTLS is more difficult than for CO. First, the $\mathrm{O}_{3}$ mixing ratio is influenced by transport from both the stratosphere (e.g. Hsu and Prather, 2009; Stevenson et al., 2013) and the troposphere (e.g. Barret et al., 2016; Zhang et al., 2016). Second, tropospheric $\mathrm{O}_{3}$ is produced from a wide variety of precursors (non-methane volatile organic compounds, $\mathrm{CO}, \mathrm{HO}_{2}$ ) emitted from numerous surface sources, both natural and anthropogenic. Third, nitrogen oxides $\left(\mathrm{NO}_{x}\right)$ implicated in the production of $\mathrm{O}_{3}$ are not only emitted at the surface by combustion processes but are also produced in the free troposphere by lightning. In parallel, nitrogen oxides can be released by the decomposition of reservoir species such as peroxyacetyl nitrate (PAN), a long-lived species that can be transported at intercontinental scales in the free troposphere (e.g. Hudman et al., 2004).

Establishing trends in $\mathrm{O}_{3}$ and $\mathrm{CO}$ with observations is important for evaluating the impact of the reduction in anthropogenic emissions in the northern midlatitudes on the atmospheric chemical composition. Trends in both gases are also important for assessing changes in atmospheric radiative forcing. Furthermore, both observed trends and climatologies (i.e. time-averaged data) are used as reference values in order to evaluate the ability of models to reproduce the past atmospheric composition and thus to forecast future changes. Consequently, assessing the mean distribution and the long-term evolution of $\mathrm{O}_{3}$ and $\mathrm{CO}$ is within the focus of several research programs dealing with the understanding of atmospheric composition regarding air quality and climate issues.

The present study is based on the measurements of these two trace gases, available in one single data set: the IAGOS database (http://www.iagos.org). In the framework of the IAGOS program (In-service Aircraft for a Global Observing System; Petzold et al., 2015), the measurements on board commercial aircraft at cruise levels $(9-12 \mathrm{~km}$ above sea level) provide accurate sampling with a high frequency in the UTLS, particularly over northern midlatitudes. With a monitoring period reaching 19 years for $\mathrm{O}_{3}$ and 12 years for $\mathrm{CO}$ in this area, the time series based on the IAGOS data set can provide helpful information for shorter aircraft campaigns, allowing the quantification of background values as an interannually variable signal. Also, with a dense geographical coverage spreading over the midlatitudinal zonal band (except the Pacific Ocean in so far as regular measurements only started in 2012), spatial distributions seen by IAGOS are a source of complementary information for local observations, quantifying the spatial variability at synoptic and intercontinental scales. The monitoring period is now sufficient to derive representative climatologies and longterm evolution of both species over different regions of interest.

Since the 1990s, several observation systems have been monitoring these two species, aiming at a better understanding of the processes controlling their spatial distribution and temporal evolution, (multi-)decadal trends and interannual variability in the UTLS. Satellite-based instruments provide global coverage but with limited vertical resolution while sondes, lidar (light detection and ranging), and aircraft in situ measurements during ascent and descent phases offer a precise view of the vertical profile over a limited area. Neu et al. (2014b) have recently presented a comprehensive intercomparison of currently available satellite $\mathrm{O}_{3}$ climatologies (gathering limb and nadir viewing) in the $300-70 \mathrm{hPa}$ range. Although suffering from a coarse vertical resolution, such an analysis offers a basis for a comparison of the large-scale spatio-temporal characteristics of the $\mathrm{O}_{3}$ distribution (e.g. zonal mean cross sections, seasonal variability, interannual variability). The authors point out the large differences in these satellite-based climatologies in the UTLS. Observing this layer often requires a more detailed picture, with a higher spatio-temporal resolution and multiple species, which can all be addressed with aircraft platforms. Tilmes et al. (2010) proposed an integrated picture of $\mathrm{O}_{3}, \mathrm{CO}$, and $\mathrm{H}_{2} \mathrm{O}$ climatologies over the Northern Hemisphere, mostly representative of North America and Europe, based on research aircraft campaigns. They provide a valuable data set representing the vertical gradients of $\mathrm{H}_{2} \mathrm{O}, \mathrm{O}_{3}$, and $\mathrm{CO}$ in three regimes: tropics, subtropics, and the polar region in the Northern Hemisphere. Compared to commercial aircraft, research aircraft can fly at higher altitudes. Such a study has taken the most advantage of this, which has made tropopause-referenced tracer profiles and tracer-tracer correlations possible and has highlighted further the transport and mixing processes in a wider vertical range. However, the IAGOS program using commercial aircraft as a multi-species measurement platform enables a better characterization of interregional differences, given its higher spatio-temporal resolution. One of the objectives of the present study is to emphasize the use of IAGOS as a complementary database to the above-mentioned ones, allowing further investigations on composition and trends in $\mathrm{O}_{3}$ and $\mathrm{CO}$ in the UTLS $(8-12 \mathrm{~km})$ in the Northern Hemisphere.

Concerning carbon monoxide, previous studies using satellite measurements have shown a significant decadal decrease in the CO column at the global scale, with a higher sensitivity in the mid-troposphere. Worden et al. (2013) found a negative trend over several northern extratropi- 
cal regions with Measurements of Pollution in the Troposphere (MOPITT) and the Atmospheric InfraRed Sounder (AIRS) respectively from 2000 to 2011 and from 2003 to 2011. Laken and Shahbaz (2014) derived a globally negative trend in the CO column with MOPITT from March 2000 to April 2012, despite significant increases in some tropical and subtropical regions. In the upper troposphere, aircraft measurements have also highlighted regional decreases in $\mathrm{CO}$ mixing ratios. A significant negative trend was derived with MOZAIC flights (Measurements of water vapor and Ozone by Airbus In-service airCraft) over western Europe from 2003 to 2009 (Gaudel et al., 2015b). More specifically above Frankfurt airport, Petetin et al. (2016) showed a decrease in $\mathrm{CO}$ using IAGOS data recorded during vertical ascents and descents from 2002 to 2012. Recently, Jiang et al. (2017) suggested that the trends in $\mathrm{CO}$ were likely to be caused by the decrease in emissions from the United States, eastern China, and Europe from 2001 to 2015, though CO emissions in the European region have levelled off since 2008.

Recent studies concerning $\mathrm{O}_{3}$ trends show more varied results. Based on SCIAMACHY (SCanning Imaging Absorption spectroMeter for Atmospheric CHartographY) tropospheric column measurements during 2003-2011, Ebojie et al. (2016) derived increases over Alaska and decreases over the North American outflow, southern Europe and Siberia. The Tropospheric Ozone Mapping System (TOMS) showed an increasing tropospheric $\mathrm{O}_{3}$ column in both the North and South Pacific Ocean at midlatitudes from 1979 to 2003. Neu et al. (2014a) highlighted an increase in mid-tropospheric $\mathrm{O}_{3}(510 \mathrm{hPa})$ in the $30-50^{\circ}$ zonal band from mid-2005 to 2010. Granados-Muñoz and Leblanc (2016) derived a $1 \sigma$ significant increase between 7 and $10 \mathrm{~km}$ above sea level (a.s.l.) over the Table Mountain Facility (TMF; $35^{\circ} \mathrm{N}, 119^{\circ} \mathrm{W}$; Jet Propulsion Laboratory, California) from 2000 to 2015 using lidar measurements. Gaudel et al. (2015a) combined lidar and ozonesondes measurements from 1991 until 2010 throughout the troposphere over the Observatoire de Haute-Provence (OHP, France). From 6 up to $8 \mathrm{~km}$ a.s.1., they found a $1 \sigma$ significant positive trend. The increase is also observed in the lower part of the free troposphere at some Global Atmospheric Watch stations (GAW). Most of the Northern Hemisphere GAW stations above $2 \mathrm{~km}$ a.s.l. show a significant positive trend (Oltmans et al., 2013), indicating that the increase probably occurs throughout the free troposphere. Free- and uppertropospheric $\mathrm{O}_{3}$ trends derived from various instruments are gathered in the reviews of Cooper et al. (2014) and Monks et al. (2015). Amongst the in situ observations, significant positive trends since 1971 are reported from ozonesonde data above western Europe and Japan and also from aircraft data in the upper troposphere above the northeastern USA, the North Atlantic Ocean, Europe, the Middle East, southern China, and Japan. More precisely, during the 1990-2010 decades, ozonesonde measurements above North America and the North Pacific Ocean showed positive trends. Thouret et al. (2006) highlighted significant positive trends for $\mathrm{O}_{3}$ mixing ratios above the eastern United States, the North Atlantic, and Europe from 1994 to 2003 with the IAGOS data set, both in the upper troposphere and in the lower stratosphere. The IAGOS time series is now 10 years longer, and the present study brings crucial information to the interpretation of the previous trends.

Whereas the bulk of these studies shows an increase in $\mathrm{O}_{3}$ and a decrease in $\mathrm{CO}$ in the free troposphere, there is no available study based on in situ measurements only in the UTLS on a decadal timescale, with a dense temporal and geographical sampling at the hemispheric scale. The objective of the present study is to examine climatologies for $\mathrm{O}_{3}$ and $\mathrm{CO}$ derived from the whole set of IAGOS measurements at cruise levels, as well as the trends in these two trace gases at a regional scale in the northern midlatitudes. It is both an update and an extension of Thouret et al. (2006), with a broader climatology and longer time series to derive trends and a more complete data set with the addition of $\mathrm{CO}$ measurements. Today, the IAGOS database allows such an analysis using regular and high-resolution measurements in the UTLS, spanning 19 years for $\mathrm{O}_{3}$ and 12 years for $\mathrm{CO}$. This paper aims at providing the most complete picture of the $\mathrm{O}_{3}$ and $\mathrm{CO}$ distributions at a hemispheric scale based on in situ measurements. We investigate regional differences in terms of seasonal cycles and trends over the northern midlatitudes. In Sect. 2 we describe the IAGOS program, the selected UTLS definition, and the methodology used to analyse the data. In Sect. 3 we present the climatologies, time series and analysis of the subsequent trends.

\section{Data and methodology}

\subsection{IAGOS data set}

The data used in this study are provided by the IAGOS European research infrastructure (www.iagos.org; Petzold et al., 2015). IAGOS consists in automatic measurements of several trace gases and aerosols on board commercial aircraft, aiming at a better understanding of the chemical composition of the atmosphere at the global scale.

IAGOS has partly taken over the MOZAIC program (Marenco et al., 1998). The measurements of ozone and water vapour started in August 1994 (Thouret et al., 1998; Helten et al., 1998). The measurements of CO started in December 2001 (Nédélec et al., 2003). Routine IAGOS-Core measurements started in July 2011, with a new concept of aircraft system (e.g. near-real-time data transmission) and instruments (e.g. combined ozone and $\mathrm{CO}$ in one single analyser, as detailed in Nédélec et al., 2015). Respectively, ozone and carbon monoxide have been monitored with dual-beam UV and IR absorption photometers. Measurements are affected by an uncertainty range of $\pm 2 \% \pm 2 \mathrm{ppb}$ for ozone 
(Thouret et al., 1998) and $\pm 5 \% \pm 5$ ppb for CO (Nédélec et al., 2003), with a temporal resolution of 4 and $30 \mathrm{~s}$.

Although the technology remained the same, the consistency between MOZAIC and IAGOS-Core data sets raised questions, and the overlapping period (2011-2014) has been used to give the users the assurance that MOZAIC-IAGOS is a unique data set (referred to as IAGOS database hereafter). Indeed, it is of particular importance to make sure that the long-term evolutions of $\mathrm{O}_{3}$ and $\mathrm{CO}$ distributions would not be biased by this technical change. A deep and thorough comparison between MOZAIC and IAGOS, based on several hundred vertical profiles over Frankfurt, has been summarized in Nédélec et al. (2015). The consistency between the two data sets has been demonstrated, and hence, the results in the present study can be considered independent of the transition from MOZAIC to IAGOS-Core. Thus, the recent study by Petetin et al. (2016), as well as the Tropospheric Ozone Assessment Report (Gaudel and Cooper, 2018) analysis commonly known as TOAR, makes use of the MOZAICIAGOS database as a seamless one. The period of the present study spreads from the start of the MOZAIC program until December 2013, since the data from the following years are not fully calibrated yet.

\subsection{Methodology}

\subsubsection{Definition for the upper troposphere and the lower stratosphere}

During each flight in extratropical latitudes, both tropospheric and stratospheric air masses are encountered. Their different properties make it necessary to distinguish between upper troposphere and lower stratosphere. Thus, we discriminate between the air masses with three varying pressure intervals, i.e. the upper troposphere (UT), the lower stratosphere (LS), and the tropopause layer (TPL) as a mixing region between.

In extratropical latitudes, the discrimination between the upper-tropospheric and the lower-stratospheric measurement points is based on the dynamical definition of the tropopause, adapted from Thouret et al. (2006): it is centred on the isosurface of potential vorticity (PV) defined as PV $=2$ pvu (1 potential vorticity unit $\equiv 10^{-6} \mathrm{~K} \mathrm{~m}^{2} \mathrm{~kg}^{-1} \mathrm{~s}^{-1}$ ). The tropopause pressure is systematically defined as the highest level of the 2 pvu isosurface. As a consequence, the double tropopause events encountered at midlatitudes, more frequently in winter (Randel et al., 2007), are not filtered out. This implies that air masses attributed to the upper troposphere are not purely tropospheric since they may include some stratospheric intrusions. As indicated in Fig. 1, the TPL is considered to be a $30 \mathrm{hPa}$ thick layer, centred on this 2 pvu isosurface. The UT and the LS are defined as constant pressure intervals relative to the tropopause, respectively $\left[P_{2}\right.$ pvu $+75 \mathrm{hPa}$, $P_{2 \text { pvu }}+15 \mathrm{hPa}$ ] and $\left[P_{2 \mathrm{pvu}}-45 \mathrm{hPa}, P_{2 \mathrm{pvu}}-150 \mathrm{hPa}\right.$ ]. The large pressure interval of the LS gathers all the stratospheric data points. The choice of a transition layer rather than a surface for the tropopause definition is motivated by the need to lower the impact of the vertical uncertainties on the PV calculations. With a thickness as great as $30 \mathrm{hPa}$, the TPL provides a clear partitioning between the characteristics of the UT and the LS. Thus, the analysis focuses on the composition and trends in these two distinct layers. Note also that a comparison between the dynamical tropopause estimate based on the PV fields and the chemical tropopause estimate based on $\mathrm{O}_{3}$ vertical profiles considering all IAGOS measurements near Frankfurt (where IAGOS data are the most numerous) have shown errors but a negligible systematic bias (Petetin et al., 2016).

The PV values have been derived using the European Centre for Medium-Range Weather Forecasts (ECMWF) operational analysis since 2000 , with a $1^{\circ} \times 1^{\circ}$ resolution, and interpolated along the aircraft trajectories. As for other ancillary data developed for the IAGOS database (www.iagos. org), the up-to-date better vertical resolution of the operational analysis since 2000 was clearly more relevant, e.g. for the representativeness of vertical transport processes and thus for the precision of the ancillary data itself. This has been demonstrated particularly for the coupling system (SOFTIO) combining the FLEXPART Lagrangian particle dispersion model and emissions inventories to provide systematic origins of $\mathrm{CO}$ mixing ratio anomalies observed by IAGOS throughout the troposphere (see Sauvage et al., 2017, for further details).

Although this study focuses on the northern midlatitudes, we also present briefly some results from measurements in the tropics. In the $25^{\circ} \mathrm{S}-25^{\circ} \mathrm{N}$ band, the tropopause is higher than any commercial aircraft flight level, since they are bounded by the $196 \mathrm{hPa}$ pressure level (below $12 \mathrm{~km}$ ). Consequently, all the IAGOS measurement points recorded above $8 \mathrm{~km}$ a.s.l. are considered to belong to the tropical UT.

\subsubsection{IAGOS data analysis}

This study gathers climatological analyses in each layer, focusing on global horizontal distributions, latitudinal averages in the northern midlatitudes, and seasonal cycles at subcontinental scales. We also present monthly time series, anomalies and subsequent long-term trends. The following paragraph summarizes the processing applied to the data for each of these analyses.

Horizontal distributions of $\mathrm{O}_{3}$ and $\mathrm{CO}$ are computed by gathering all IAGOS measurements recorded into $5^{\circ} \times 5^{\circ}$ cells, with respect to the season and the layer. Averages are calculated only in cells where the amount of observations exceeds 2000 (1000) for $\mathrm{O}_{3}$ (CO) over the period 1995-2013 (2002-2013). The horizontal distribution of $\mathrm{O}_{3} / \mathrm{CO}$ ratios is also computed by averaging the instantaneous $\mathrm{O}_{3} / \mathrm{CO}$ ratios in each cell. The selected size of the cells and thresholds in the amount of data ensure a good representativeness of the 

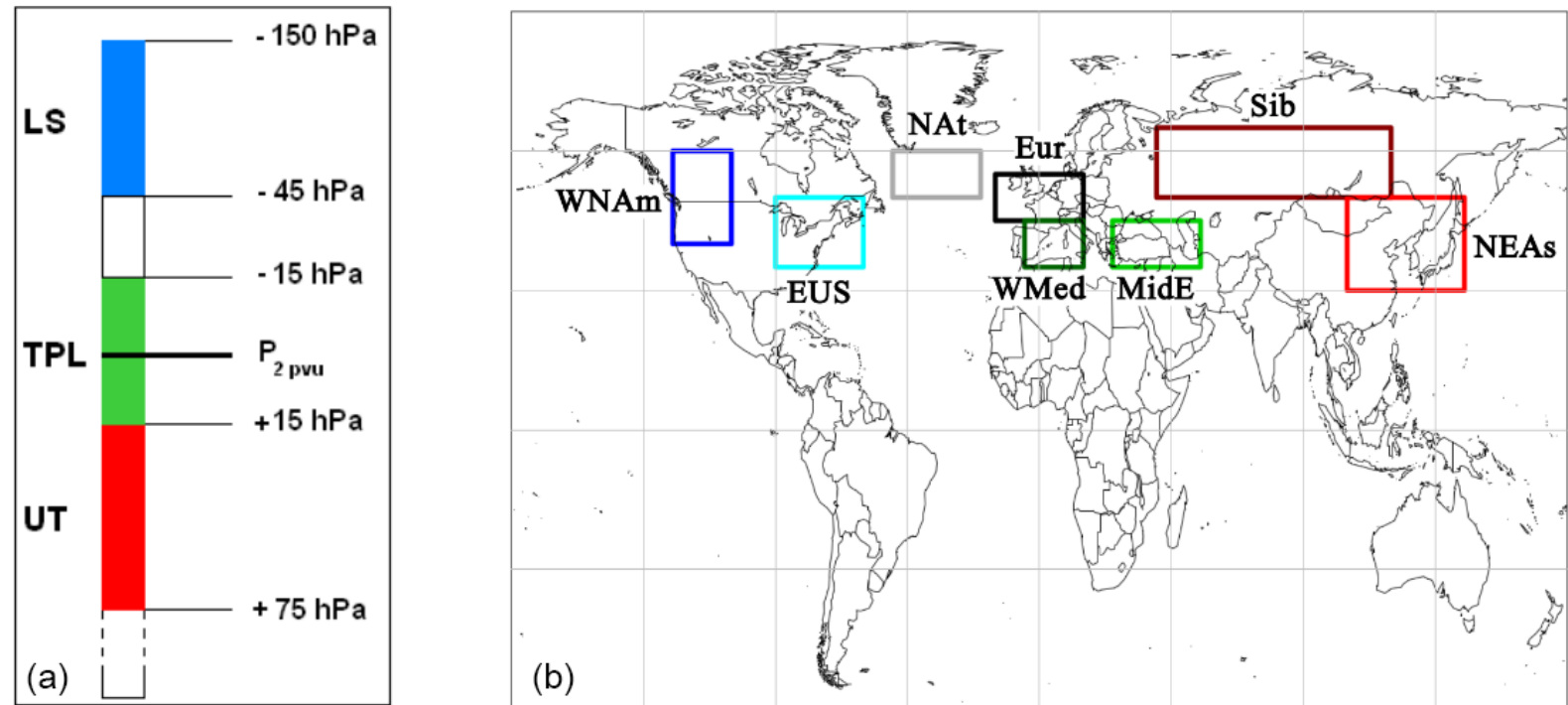

Figure 1. (a) Schematic representation of the definition of the upper troposphere (UT), tropopause layer (TPL), and lower stratosphere (LS) in red, green, and blue respectively. The pressure levels are indicated on the right, relatively to the PV isosurface $\left(P_{2}\right.$ pvu $)$. (b) Map of the regions compared in this study. From west to east: western North America (WNAm), the eastern United States (EUS), the North Atlantic (NAt), Europe (Eur), the Western Mediterranean basin (WMed), the Middle East (MidE), Siberia (Sib), and northeastern Asia (NEAs).

time period, without filtering out too high a proportion of data.

We perform a subcontinental-scaled analysis in order to take the zonal variability into account. Indeed, averages made in continental-sized regions or in zonal bands are not fitted for IAGOS data because of the high geographical variability in the measurements. In eight regions of interest (see Fig. 1), monthly time series are calculated by averaging all corresponding instantaneous observations (not by averaging the $5^{\circ} \times 5^{\circ}$ binned data). These monthly averages are calculated only when (i) the amount of available data points in a month exceeds 300 and (ii) the first and last measurements are separated by a 7-day period at least. These selected thresholds limit the influence of short-term events which are not representative of the whole month. The boundaries of each region are chosen as a compromise between a high level of sampling and a good representativeness of the expected impact of local surface emissions and meteorological conditions. Based on these monthly time series, mean seasonal cycles are computed over the period 1995-2013. In order to avoid inter-seasonal biases due to the interannual variability, we retained only the years with data available during 7 months distributed over at least three seasons. A test has been done that required available data for all four seasons. It slightly reduced the amount of complete years ( 2 years or less removed for each region), yielding quasi-identical results. The seasonal cycles have also been found to be poorly sensitive to a 2-month change in the amount of required months per year. These mean seasonal cycles in all regions are used to extract deseasonalized monthly anomalies from the original monthly time series. Based on the same population of data points as used for calculating the mean values, other useful metrics like the 5th and 95th percentiles of the $\mathrm{O}_{3}$ and $\mathrm{CO}$ mixing ratios are also calculated, as well as the $\mathrm{O}_{3} / \mathrm{CO}$ ratio.

Based on these monthly anomalies, the trends are computed using non-parametric Mann-Kendall analysis combined with a Theil-Sen slope estimate (Sen, 1968). Calculations are performed with the OpenAir R package dedicated to atmospheric sciences (Carslaw and Ropkins, 2012). The Theil-Sen slope estimate corresponds to the median of the slopes defined by each pair of points. In this paper, all trend uncertainties are given at a $95 \%$ confidence interval (i.e. with a statistical significance above $2 \sigma$ ). The linear regression is based on the hypothesis that every point is independent of its neighbours. As a consequence, a positive (negative) autocorrelation can lead to an overestimation (underestimation) of the regression slope. In the aim of reducing such kinds of bias, the method implemented in the OpenAir package applies a correcting factor to one half of the confidence interval depending on the autocorrelation. More details are available in the OpenAir Manual (https://cran.r-project.org/web/ packages/openair/openair.pdf).

The statistics of IAGOS data are summarized in Table 1 for each region and each layer. Northwest America is the least sampled region $(\simeq 60 \%$ of available months and $\simeq 1400$ flights in each layer) with a shorter time coverage per month ( $\simeq 18$ days per month): consequently, a mean value computed in this region is less likely to be a representative estimation of the monthly mean volume mixing ratio (VMR). Aside from this region, the next least sampled regions are the Western Mediterranean basin, Siberia, and northeast Asia $(\simeq 75 \%$ of available months with $\simeq 3000$ flights in each 
Table 1. Regional characteristics and data statistics in each layer. The third and fourth columns refer to the proportion of available monthly data relatively to the whole period: August 1994-December 2013 for $\mathrm{O}_{3}$ and December 2001-December 2013 for CO. The fifth and sixth columns indicate the total number of selected flights. The seventh and eighth columns show the time interval $\Delta t$ separating the first and the last days of measurements, averaged over the available data months.

\begin{tabular}{|c|c|c|c|c|c|c|c|}
\hline \multirow{2}{*}{ Region } & \multirow{2}{*}{ Layer } & \multicolumn{2}{|c|}{$\begin{array}{c}\text { Avail. } \\
\text { months (\%) }\end{array}$} & \multicolumn{2}{|c|}{ No. of flights } & \multicolumn{2}{|c|}{$\begin{array}{c}\Delta t \\
\left(\text { days }_{\text {month }}{ }^{-1}\right)\end{array}$} \\
\hline & & $\mathrm{O}_{3}$ & $\mathrm{CO}$ & $\mathrm{O}_{3}$ & $\mathrm{CO}$ & $\mathrm{O}_{3}$ & $\mathrm{CO}$ \\
\hline Western NAm (WNAm) & LS & 53 & 65 & 1215 & 1160 & 21 & 22 \\
\hline$\left(125-105^{\circ} \mathrm{W}\right)$ & TPL & 53 & 66 & 1402 & 1338 & 22 & 23 \\
\hline$\left(40-60^{\circ} \mathrm{N}\right)$ & UT & 50 & 66 & 1471 & 1438 & 22 & 23 \\
\hline Eastern USA (EUS) & LS & 94 & 92 & 8536 & 3701 & 27 & 26 \\
\hline$\left(90-60^{\circ} \mathrm{W}\right)$ & TPL & 94 & 92 & 10503 & 4418 & 27 & 27 \\
\hline$\left(35-50^{\circ} \mathrm{N}\right)$ & UT & 94 & 92 & 11607 & 4998 & 27 & 27 \\
\hline North Atlantic (NAt) & LS & 94 & 92 & 9125 & 4149 & 27 & 27 \\
\hline$\left(50-20^{\circ} \mathrm{W}\right)$ & TPL & 93 & 91 & 7706 & 3488 & 27 & 26 \\
\hline$\left(50-60^{\circ} \mathrm{N}\right)$ & UT & 91 & 89 & 5299 & 2550 & 25 & 25 \\
\hline Europe (Eur) & LS & 96 & 94 & 13939 & 7217 & 29 & 28 \\
\hline$\left(15^{\circ} \mathrm{W}-15^{\circ} \mathrm{E}\right)$ & TPL & 97 & 94 & 21162 & 10812 & 29 & 29 \\
\hline$\left(45-55^{\circ} \mathrm{N}\right)$ & UT & 97 & 94 & 25021 & 13129 & 29 & 29 \\
\hline Western Med. (WMed) & LS & 64 & 55 & 1806 & 1126 & 23 & 25 \\
\hline$\left(5^{\circ} \mathrm{W}-15^{\circ} \mathrm{E}\right)$ & TPL & 69 & 60 & 2074 & 1305 & 23 & 25 \\
\hline$\left(35-45^{\circ} \mathrm{N}\right)$ & UT & 70 & 60 & 2025 & 1182 & 24 & 24 \\
\hline Middle East (MidE) & LS & 89 & 88 & 3516 & 2260 & 24 & 23 \\
\hline$\left(25-55^{\circ} \mathrm{E}\right)$ & TPL & 88 & 85 & 3362 & 2107 & 24 & 23 \\
\hline$\left(35-45^{\circ} \mathrm{N}\right)$ & UT & 82 & 76 & 2846 & 1713 & 23 & 23 \\
\hline Siberia (Sib) & LS & 76 & 68 & 4615 & 2126 & 26 & 26 \\
\hline$\left(40-120^{\circ} \mathrm{E}\right)$ & TPL & 76 & 65 & 3808 & 1779 & 26 & 25 \\
\hline$\left(50-65^{\circ} \mathrm{N}\right)$ & UT & 72 & 61 & 2274 & 1159 & 24 & 24 \\
\hline Northeastern Asia (NEAs) & LS & 74 & 65 & 3502 & 1676 & 26 & 25 \\
\hline$\left(105-145^{\circ} \mathrm{E}\right)$ & TPL & 73 & 63 & 4326 & 2021 & 26 & 26 \\
\hline$\left(30-50^{\circ} \mathrm{N}\right)$ & UT & 76 & 64 & 4834 & 2323 & 27 & 26 \\
\hline
\end{tabular}

layer), with a temporal range of 22 days per month on average. Finally, the eastern United States, the North Atlantic, and northwestern Europe - referred to as Europe hereafter are the most sampled regions $(\simeq 96 \%$ of available months with $\simeq 9000$ flights in each layer in the eastern United States and the North Atlantic and more than 10000 in Europe) with a mean temporal range of 27 days per month.

In order to ensure a good representativeness of the whole measurement period for the trend analyses, we consider the best estimate slope as realistic if the ratio of available months is higher than or equal to $60 \%$. Indeed, for each species and each layer, every region fulfilling that condition is sampled almost from the start to the end of the measurement period (as shown later). Consequently, our analysis includes neither the trends in $\mathrm{O}_{3}$ in the whole UTLS above northwest America nor the trends in CO in the LS above the Western Mediterranean basin.

\section{Results}

We first present the analysis of the new set of climatologies as an update of previous studies made with a shorter data set, and based on the same tropopause definition (Thouret et al., 2006; Petzold et al., 2015) as described in Sect. 2.2.1. The present section starts with the characterization of the seasonal distributions at the global scale. It is followed by the analysis of the seasonal cycles over the eight regions defined in Fig. 1. Finally, we present the analysis of the regional longterm trends (12 years for $\mathrm{CO}, 19$ years for $\mathrm{O}_{3}$ ).

\subsection{Horizontal distributions of $\mathrm{O}_{3}$ and $\mathrm{CO}$}

Figures 2 and 3 show the seasonally averaged distribution of $\mathrm{CO}$ and $\mathrm{O}_{3}$ respectively in the UT, in $5^{\circ} \times 5^{\circ}$ bins. We use the same colour scale for the four maps to highlight the seasonal and regional differences. By averaging over the latitude range $25-75^{\circ} \mathrm{N}$ all the cells for each $5^{\circ}$ interval in longitude, we 

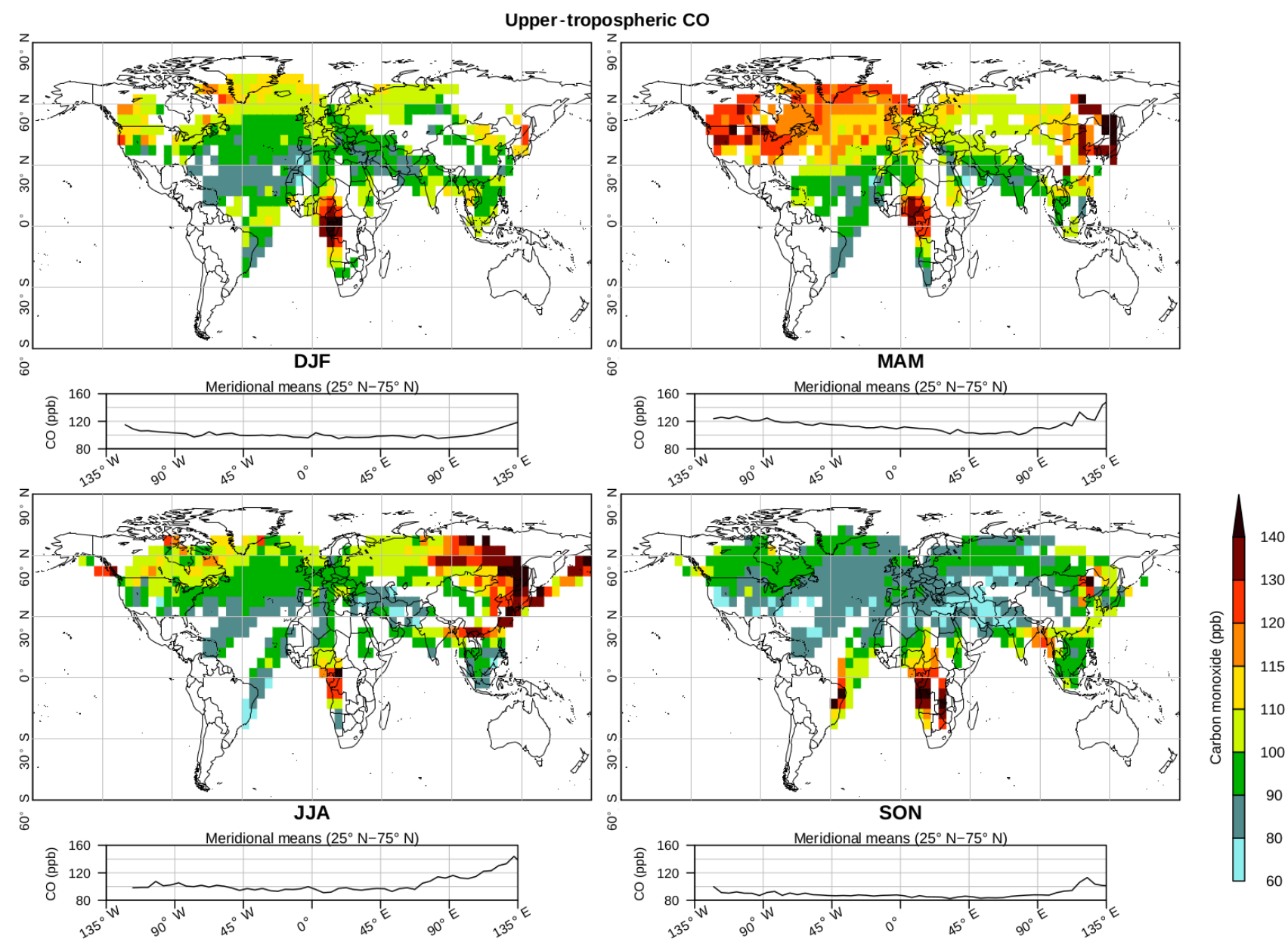

Figure 2. Horizontal distributions of CO volume mixing ratios in the UT, averaged from December 2001 to November 2013 for each season. Each 2-D distribution is projected onto the zonal axis below, with a meridional average of the northern extratropical zonal band (from 25 to $\left.75^{\circ} \mathrm{N}\right)$. The 2-D (1-D) distributions have a $5^{\circ} \times 5^{\circ}\left(5^{\circ}\right)$ resolution. The $x$ axes are the same in the maps and in the projections below. Note the larger colour interval from 60 to $80 \mathrm{ppb}$ and the smaller intervals from 110 to $120 \mathrm{ppb}$.

obtain a zonal distribution that is projected below each map. It allows us to examine the zonal gradients in $\mathrm{O}_{3}$ or $\mathrm{CO}$ and to highlight intercontinental differences. The averaging interval has been chosen in order to include all upper-tropospheric IAGOS measurements in the area considered here as the extratropics. We sometimes refer to Appendix Fig. A1 as support for our analysis. It represents the seasonally averaged distribution of the $\mathrm{O}_{3} / \mathrm{CO}$ ratio in the UT, following the same organization as in Figs. 2 and 3.

In Fig. 2, the horizontal distributions of $\mathrm{CO}$ mixing ratios reveal an overall spring maximum at northern midlatitudes, extending into summer over eastern Asia and the Bering Sea. There are also systematic maxima in the sampled tropical regions (i.e. Brazilian coast, central and southern Africa, southeast Asia), depending on their respective dry seasons. These features characterize the combination of the two most important sources, namely the anthropogenic emissions and the boreal/tropical biomass burning. At northern midlatitudes, in contrast to near-surface observations (e.g. Zbinden et al., 2013), the averaged CO mixing ratio is higher during spring in the UT. During winter, the weaker convection and the longer lifetime of $\mathrm{CO}$ allow the accumulation of this trace gas in the lower troposphere despite the stronger wintertime frequency of warm conveyor belts (e.g. Madonna et al., 2014), thus leading to a climatological maximum spread from late winter until early spring (e.g. in western Europe: Petetin et al., 2016). As the convection activity increases, the $\mathrm{CO}$ confined to the lower troposphere starts being uplifted to the UT. During summer, CO is less abundant in the lower layers, and photochemical activity reaches its maximum, acting as a major sink for $\mathrm{CO}$ by $\mathrm{OH}$ attack (e.g. Lelieveld et al., 2016). In the tropics, the local maxima occur during SON over the Brazilian coast, during the whole year over tropical Africa, and during JJA-SON over the Bay of Bengal-Southeast Asia. The maxima over tropical Africa are shifted northward during MAM and southward during SON. 


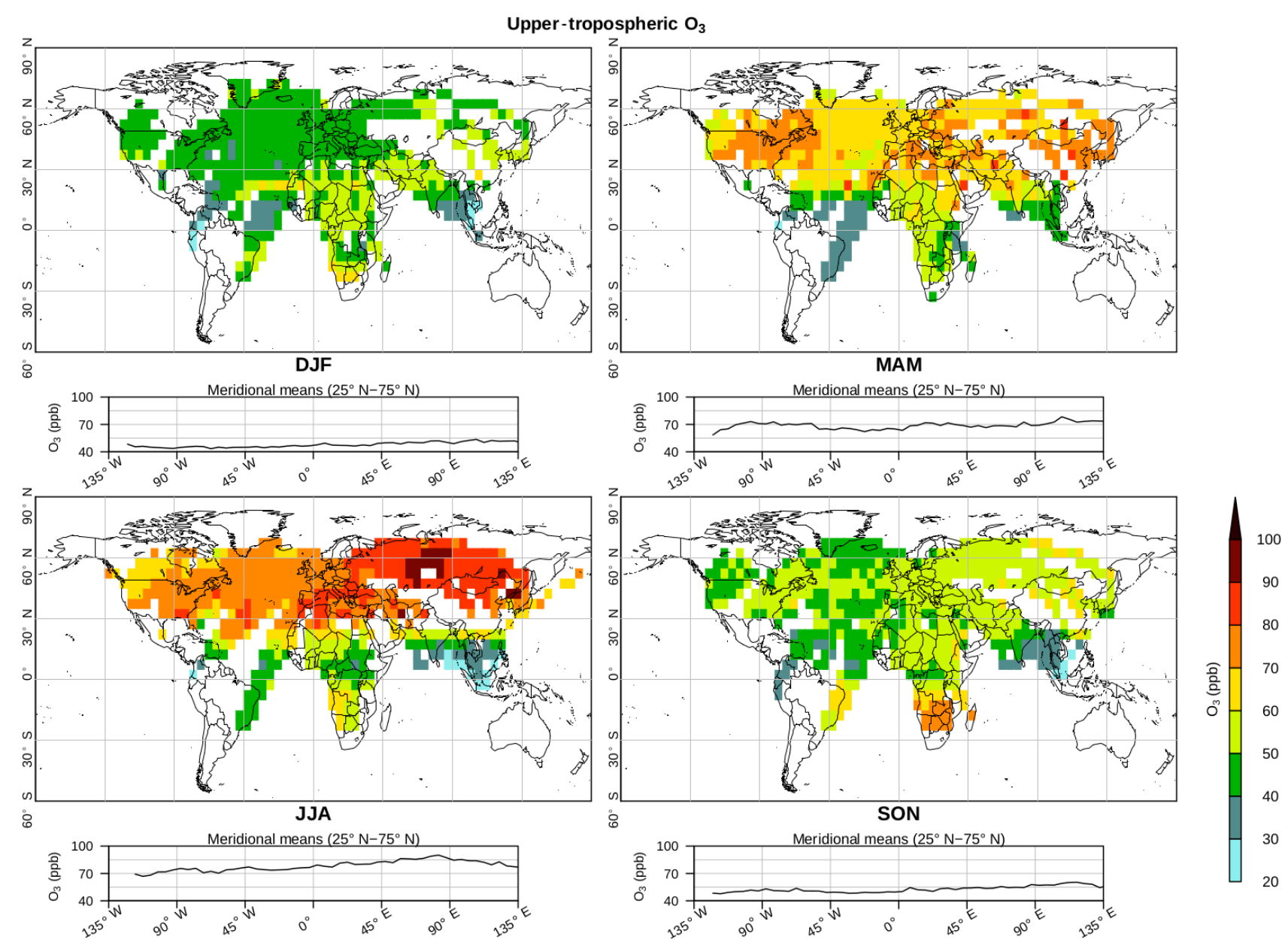

Figure 3. Horizontal distributions of $\mathrm{O}_{3}$ volume mixing ratios in the UT averaged from December 1994 to November 2013, in every season. Each 2-D distribution is projected onto the zonal axis below, with a meridional average of the northern extratropical zonal band (from 25 to $\left.75^{\circ} \mathrm{N}\right)$. The 2-D (1-D) distributions have a $5^{\circ} \times 5^{\circ}\left(5^{\circ}\right)$ resolution. The $x$ axes are the same in the maps and in the projections below.

All these local maxima observed in the UT are not necessarily correlated with the dry seasons when biomass burning emissions are enhanced because surface emissions are uplifted more efficiently during the wet seasons within deep convection (Liu et al., 2010). Further details on the distribution of $\mathrm{CO}$ and $\mathrm{O}_{3}$ near these locations, as seen by IAGOS, may be found in Sauvage et al. $(2005,2007 a, c)$ and Yamasoe et al. (2015). Globally, the highest values are recorded over eastern Asia (up to $170 \mathrm{ppb}$ ), the Bering Sea (165 ppb), North America (150 ppb), subtropical Africa (145 ppb) and the Brazilian coast (145 ppb).

The horizontal distributions of the $\mathrm{O}_{3} / \mathrm{CO}$ ratio in Fig. A1 are anticorrelated with most $\mathrm{CO}$ maxima in Fig. 2. In the tropics, low values between 0.4 and 0.5 are observed during the whole year over equatorial Africa and during JJASON over the Bay of Bengal-Southeast Asia. In the northern midlatitudes, the low ratios correlated with high $\mathrm{CO}$ values are found during the whole year over eastern Asia and during summer over the northernmost Pacific area, over the west coast of Canada, and, in the same country, over Nunavut and the northern Labrador peninsula. These $\mathrm{CO}$ maxima are characterized by a higher anticorrelation between $\mathrm{O}_{3}$ and $\mathrm{CO}$, showing a stronger impact of lower-tropospheric air masses.

Further vertical information is made available with the intercomparison between the IAGOS data set and several satellite-based instruments, which have different vertical sensitivity profiles. Laat et al. (2010) present the horizontal distribution of yearly averaged CO column from SCIAMACHY during 2004-2005 (see their Fig. 7, top left panel), with an almost vertically uniform sensitivity. The maxima observed by IAGOS over central Africa and over Southeast Asia, the latter during summer, are well represented. Both reach more than $2.75 \times 10^{18}$ molecules $\mathrm{cm}^{-2}$. By contrast, the fall maximum over the Brazilian coast observed by IAGOS is not visible in the SCIAMACHY columns. All those three (sub)tropical maxima seen by IAGOS are visible in the seasonal climatologies of MOPITT total columns from 2001 to 2012 (Osman et al., 2016) and Aura Microwave 


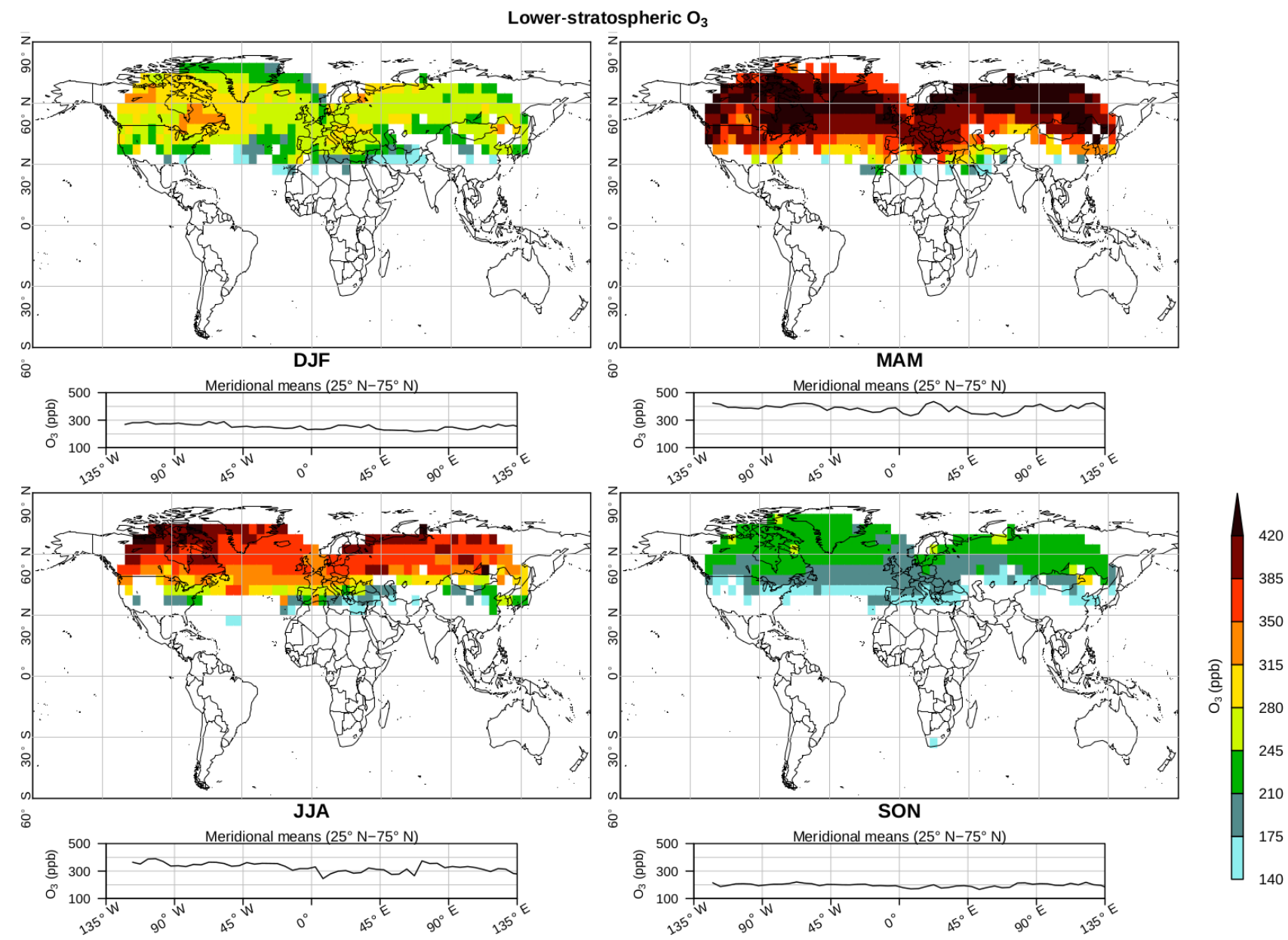

Figure 4. Horizontal distributions of $\mathrm{O}_{3}$ volume mixing ratios in the LS averaged from December 1994 to November 2013 , in every season. Each 2-D distribution is projected onto the zonal axis below, with a meridional average of the northern extratropical zonal band (from 25 to $\left.75^{\circ} \mathrm{N}\right)$. The 2-D (1-D) distributions have a $5^{\circ} \times 5^{\circ}\left(5^{\circ}\right)$ resolution. The $x$ axes are the same in the maps and in the projections below. As explained in Sect. 2.2.1, there are no data in the subtropical stratosphere.

Limb Sounder (Aura MLS) mixing ratios at $215 \mathrm{hPa}$ (Huang et al., 2016). In the northern extratropics, the main difference to the MLS climatology by Huang et al. (2016) lies in the springtime and summertime maxima over eastern Siberia and Manchuria observed by IAGOS only. One possible reason is that the altitude level at $215 \mathrm{hPa}$ in the extratropics is generally included in the LS according to our tropopause definition, despite the associated $5 \mathrm{~km}$ vertical resolution of MLS in the UTLS, which allows upper-tropospheric CO to impact the measurements at $215 \mathrm{hPa}$.

Seasonal maxima highlighted in these decadal climatologies are consistent with extreme $\mathrm{CO}$ events already recorded in the UT over eastern Asia (Nédélec et al., 2005), the northern Pacific Ocean (Clark et al., 2015), and downwind of Alaskan forest fires (Elguindi et al., 2010) and in the LS downwind of Alaska and Yukon right to the eastern coast of the Atlantic Ocean (Cammas et al., 2009). All of them originated from intense biomass burning.
In the northern extratropical UT, the common characteristic of the four seasons lies in the eastward increase in a climatological $\mathrm{CO}$ mixing ratio from 60 to $135^{\circ} \mathrm{E}$. The difference in $\mathrm{CO}$ mixing ratios reaches $\simeq 20 \mathrm{ppb}$ during fall and winter and $\simeq 40 \mathrm{ppb}$ during spring and summer. There is also a low decrease from $120^{\circ} \mathrm{W}$ to $60^{\circ} \mathrm{E}, \simeq 20 \mathrm{ppb}$ in spring and within $10 \mathrm{ppb}$ during the rest of the year. It is likely the resulting combination of stronger emissions from both anthropogenic and biomass burning over the Asian continent (e.g. Jiang et al., 2017) and an efficient vertical transport over the area (Madonna et al., 2014; Huang et al., 2016).

The 20-year seasonal distribution of $\mathrm{O}_{3}$ in the UT is shown in Fig. 3. The longitudinal variability is more detailed in the projections below the 2-D distributions, where the $5^{\circ} \times 5^{\circ}$ seasonal means are meridionally averaged from 25 to $75^{\circ} \mathrm{N}$. At northern midlatitudes, ozone clearly exhibits a minimum during winter $\left(47 \mathrm{ppb}\right.$ on average in the $25-65^{\circ} \mathrm{N}$ zonal 
band) and a maximum during summer (79 ppb), characterizing the seasonal peak of photochemical activity.

The highest values exceed $90 \mathrm{ppb}$ over Siberia and northeastern China, while minima below $30 \mathrm{ppb}$ are located on both sides of the equatorial Pacific Ocean, at least during the wet seasons (i.e. from December until February on the western South American coast and from December to March on the Maritime Continent). In the Northern Hemisphere, throughout the year, the $\mathrm{O}_{3}$ mixing ratio is higher on the eastern half of the extratropical zonal band: the annual mean in the Asian continent $\left(30-140^{\circ} \mathrm{E}\right)$ is $11 \%$ higher than in the western part $\left(125^{\circ} \mathrm{W}-15^{\circ} \mathrm{E}\right)$. The collocated maxima in the $\mathrm{O}_{3} / \mathrm{CO}$ ratio (Fig. A1) indicate a higher occurrence of correlated $\mathrm{O}_{3}$-rich and low-CO air masses, suggesting a stronger influence from the lower stratosphere.

In the Southern Hemisphere, the $\mathrm{SON}$ maximum in $\mathrm{O}_{3}$ over the Brazilian coast mostly reflects the influence of lightning in South America (Bremer et al., 2004; Sauvage et al., 2007b; Yamasoe et al., 2015). The minima observed at both sides of the equatorial Pacific Ocean during the respective wet seasons can highlight the strong convection of low-ozone air masses from the tropical marine boundary layer, typically ranging from 10 to $30 \mathrm{ppb}$ (e.g. Thompson et al., 2003).

The satellite-based instruments SCIAMACHY and the Ozone Monitoring Instrument-Microwave Limb Sounder (OMI-MLS) provided climatologies of the tropospheric $\mathrm{O}_{3}$ column, averaged respectively from 2003 to 2011 and from October 2004 to December 2010. They both showed a springtime maximum and a geographical maximum over the Atlantic Ocean between 30 and $45^{\circ} \mathrm{N}$, which is due to stratosphere-troposphere exchange events and surface transport of pollution from the eastern USA during spring and summer (Fig. 1 in Ebojie et al., 2016; Fig. 5a-c in Ziemke et al., 2011). The discrepancies with the IAGOS climatologies can be due to uncertainties involving the stratospheric signal, i.e. the ozone stratospheric column, and/or the height of the tropopause (Ebojie et al., 2014). The summertime climatology of the $\mathrm{O}_{3}$ mixing ratio at $464 \mathrm{hPa}$ provided by the Tropospheric Emission Spectrometer (TES) from 2005 to 2010 in Verstraeten et al. (2013, Fig. 1) shows similar features to the IAGOS climatology. The $\mathrm{O}_{3}$ mixing ratios are higher above the Asian continent than west of $15^{\circ} \mathrm{E}$, and there is a local maximum above Manchuria (northeastern China). In the tropics, the maximum over equatorial Africa and the minimum above and east of the Maritime Continent are also seen with TES. At least in the extratropics, the altitude range observed with TES corresponds to $100-150 \mathrm{hPa}$ below the lower limit of our definition of the UT. Thus, in summer, the properties we observe in the UT may extend downward, representing a wider upper part of the free troposphere.

In the tropics, Livesey et al. (2013) used Aura MLS observations at $215 \mathrm{hPa}$ since 2004 until 2011. They highlighted CO maxima over India and southeast Asia during JulyAugust, northern equatorial Africa in February-April, south- ern equatorial Africa in September-November, and equatorial Brazil in October-November. According to their study and references therein, the two maxima over Asian regions are linked to anthropogenic emissions uplifted to the tropical UT by strong convection (Jiang et al., 2007), whereas the other maxima originate from biomass burning. Most of these maxima are consistent between the MLS and IAGOS data sets. One exception may be northern India $\left(25-30^{\circ} \mathrm{N}\right.$ cells) where IAGOS does not clearly highlight a summertime maximum. However, available IAGOS data in this region and season are too scarce to draw a strong conclusion, likely because IAGOS aircraft often fly below the UT lower boundary $\left(P_{2 \mathrm{pvu}}+75 \mathrm{hPa}\right)$ in the $25-30^{\circ} \mathrm{N}$ zonal band that becomes subtropical in summer, with a tropopause typically above the $150 \mathrm{hPa}$ altitude level. $\mathrm{O}_{3}$ maxima are also shown by MLS above subtropical Brazil and southern subtropical Africa during September-November. Last, the climatological means they derived reached their geographical minima all along the equatorial Pacific Ocean $\left(15^{\circ} \mathrm{S}-15^{\circ} \mathrm{N}\right)$, which is consistent with the overall minima observed by IAGOS at both sides of the equatorial Pacific Ocean.

The results shown in Fig. A1 motivated our choice in several regions of interest presented in Sect. 2.2.2. Lower values characterize northwest America and northeast Asia, whereas higher values are found over the whole Mediterranean basin and especially over the Middle East.

The horizontal distribution of the $\mathrm{O}_{3}$ mixing ratios in the LS is presented in Fig. 4. It contrasts with the uppertropospheric distribution, thus confirming the present definition of tropopause as a realistic transition layer between the troposphere and the stratosphere. The lower-stratospheric climatology is characterized by a strong maximum during spring (approximately 33\% more than the annual concentrations). It originates from the January-February maximum of the downward $\mathrm{O}_{3}$ flux at $\theta=380 \mathrm{~K}$, both driven by the Brewer-Dobson circulation and by the stratospheric photochemistry which activates at the end of winter. This feature is followed by approximately 100 days of transport until reaching the tropopause (Olsen et al., 2004). In the low latitudes of the northern extratropics, the distribution shows a poleward gradient, consistent with the adiabatic transport between the tropical UT and the extratropical lowermost stratosphere. For all seasons but autumn, the highest values are observed over Canada-Greenland and northern Siberia. During spring, these results are coherent with the climatology of the downward $\mathrm{O}_{3}$ flux shown in Olsen et al. (2013, Fig. 5), where the $\mathrm{O}_{3}$ mixing ratios derived from MLS observations in the stratosphere $(\theta=380 \mathrm{~K})$ are combined with the MERRA reanalysis meteorological fields.

\subsection{Regional seasonal cycles}

In order to further assess the regional variability in $\mathrm{O}_{3}$ and $\mathrm{CO}$ mixing ratios, we analysed the time series of the eight regions displayed in Fig. 1 and defined in Table 1. We first 


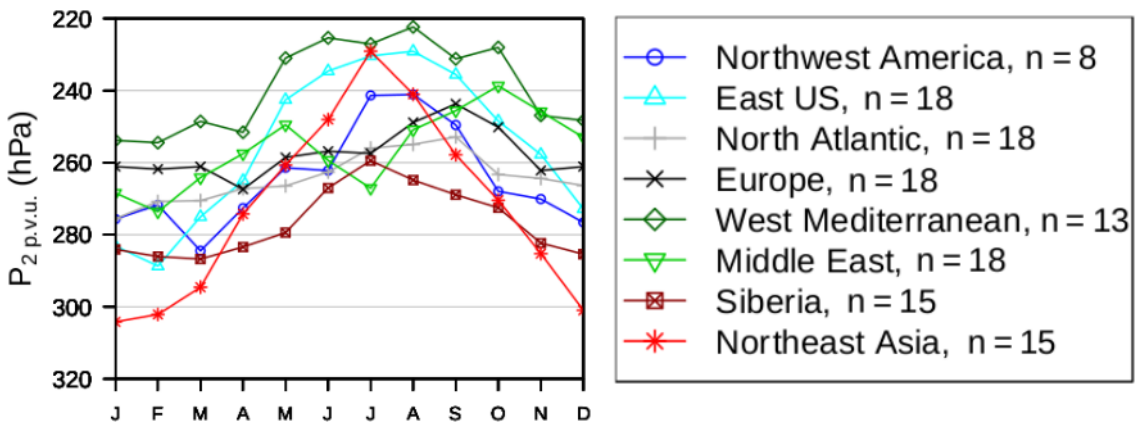

Figure 5. Mean seasonal cycles of $P_{2}$ pvu $(\mathrm{hPa})$ in each region. The average has been calculated by selecting the same years as for the $\mathrm{O}_{3}$ mixing ratio; this amount is indicated in the legend as the number $n$.

compare the mean seasonal cycles, before characterizing and analysing the anomalies, and then derive the trends. In order to make a first estimate of the interregional variability in the two trace gases, the mean seasonal cycles are displayed in Fig. 6. Similarly, we show the seasonal cycles of the $\mathrm{O}_{3}$-to$\mathrm{CO}$ ratio in order to provide a synthesis between the two data sets. First of all, as a support for our analysis, we present the seasonal cycles for the mean pressure at the 2 pvu altitude in Fig. 5.

All regions exhibit a higher tropopause in summer. The northernmost region (Siberia) is characterized by the lowest tropopause altitude, whereas the higher tropopause altitudes occur in one of the southernmost regions (the Western Mediterranean basin).

Complementary information is shown in Figs. 7, 8, and 9, representing the seasonal cycles of $\mathrm{O}_{3}, \mathrm{CO}$, and $\mathrm{O}_{3} / \mathrm{CO}$ respectively for the monthly 5 th percentile (P5), mean value and 95th percentile (P95). The interannual variability (IAV) is illustrated by the error bars and defined as an interannual standard deviation of the monthly mean value. We first present the main characteristics in each of these three figures and their corresponding columns in Fig. 6, before analysing and discussing the regional behaviours.

In Fig. 6, the mean $\mathrm{O}_{3}$ mixing ratio (panels a, d, g) shows a similar seasonal cycle for all regions. On average, the upper-tropospheric $\mathrm{O}_{3}$ mixing ratio ranges from $46 \pm 4 \mathrm{ppb}$ in December-January up to $81 \pm 7 \mathrm{ppb}$ in JuneJuly, while the lower-stratospheric $\mathrm{O}_{3}$ mixing ratio ranges from $180 \pm 20 \mathrm{ppb}$ in October-November up to $410 \pm 43 \mathrm{ppb}$ in April-May; this is given as mean \pm IAV. The IAV indicated here (not shown in Fig. 6) is averaged over the regions. The seasonal maximum generally occurs in June-July in the UT, May-June in the TPL, and April-May in the LS. This feature highlights a seasonal cycle in the TPL halfway between upper-tropospheric and lower-stratospheric cycles and confirms again the tropopause definition used here as a realistic transition between the troposphere and the stratosphere. The seasonal cycles of the mean $\mathrm{CO}$ mixing ratio (central column) show a broader range of variability between the regions. The five western regions (northwest America, the eastern United States, the North Atlantic, Europe, and the Western Mediterranean basin) exhibit a spring maximum and a late summer-fall minimum in the UT and in the TPL. Asian regions (Siberia, northeast Asia) present a different behaviour in the UT with a broad spring-summer maximum. Northwest America is noticeable for the highest mixing ratios recorded from November to April. Siberia shows a significant maximum in July. The relative seasonal amplitude - here defined as the $\frac{\max -\text { min }}{\text { mean }}$ ratio - ranges from $33 \%$ in the Western Mediterranean basin up to $46 \%$ in northwest America. In comparison, the seasonal variations in $\mathrm{CO}$ in the LS are substantially lower in most regions. In this layer, the relative seasonal amplitude reaches its maximum at $27 \%$ in the Middle East, followed by substantially lower amplitudes at $22 \%$ in northeast Asia and the eastern United States and within the $16-18 \%$ range in the other regions. The $\mathrm{O}_{3} / \mathrm{CO}$ mean value (Fig. $6 \mathrm{c}, \mathrm{f}, \mathrm{i}$ ) ranges between 0.4 and 1.0 in the UT with a clear maximum in summer for all the regions. It ranges between 0.7 and 1.5 in the TPL and shows discrepancies amongst the regions, mostly due to the interregional variability in the $\mathrm{CO}$ seasonal cycle. In the Western Mediterranean basin and the Middle East, the maxima occur during June-July, similarly to the upper-tropospheric cycles. In northwest America, Europe, Siberia, and northeast Asia, the maxima are shifted in May-June. In the North Atlantic Ocean and in the eastern USA, the maxima are steeper and occur during May and April respectively. This $\mathrm{O}_{3} / \mathrm{CO}$ ratio varies from 3 up to 13 in the LS, with early maxima from February until May in the eastern USA, the Western Mediterranean basin, and the Middle East, whereas the maxima generally occur from April until June in the other regions. These differences in the LS arise from the higher summertime stratospheric CO mean values in the eastern USA, the Western Mediterranean basin, and the Middle East and lower summertime stratospheric ozone mean values in the last two regions. The different ranges of the ratio between the three layers also confirm that our so-called tropopause layer is clearly a transition zone between the UT and the LS. 
(a) LS

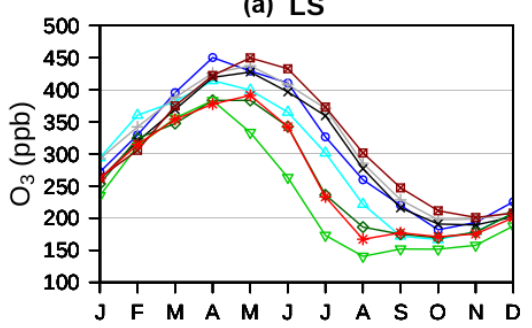

(d) TPL

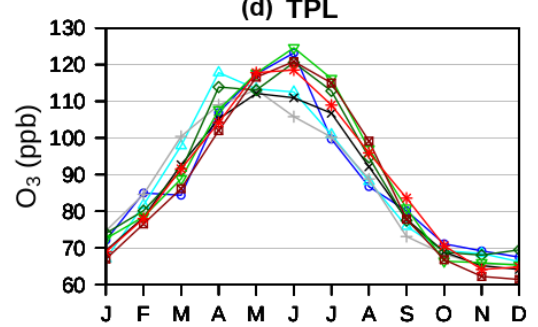

(g) UT

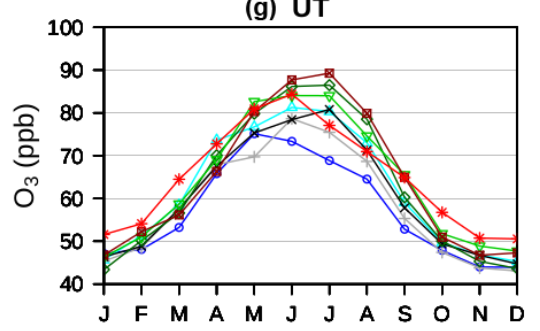

(b) LS

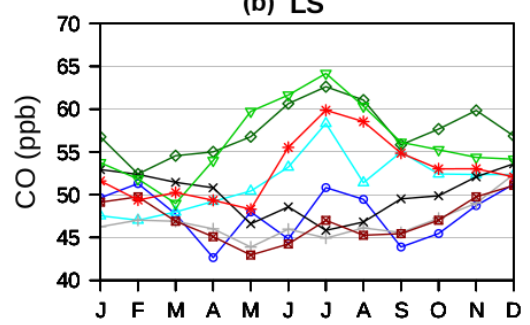

(e) TPL

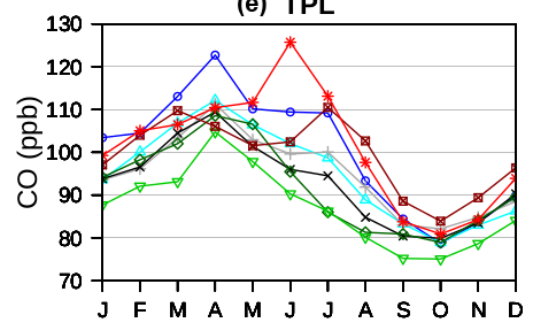

(h) UT

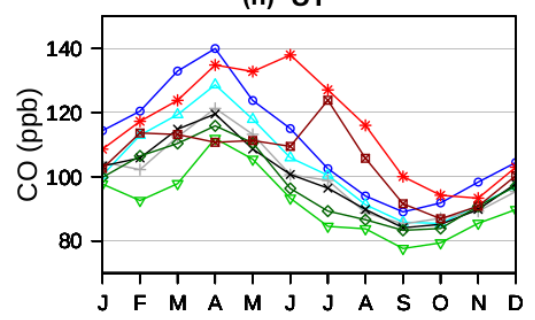

(c) LS

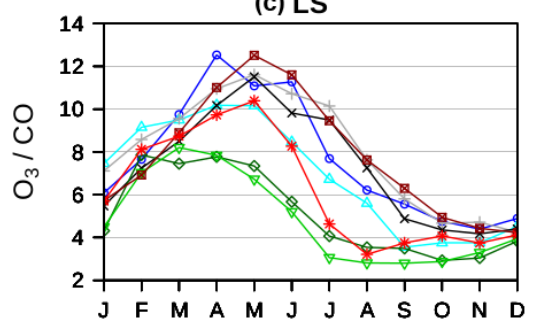

(f) TPL

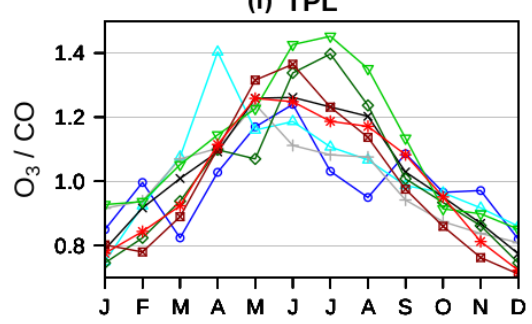

(i) UT

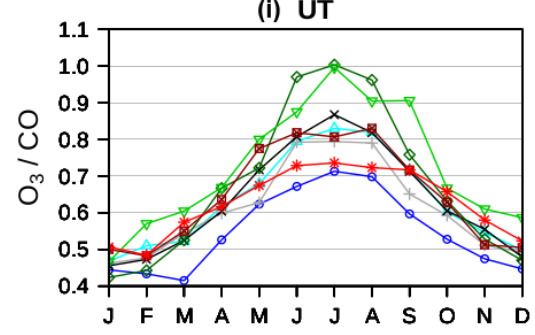

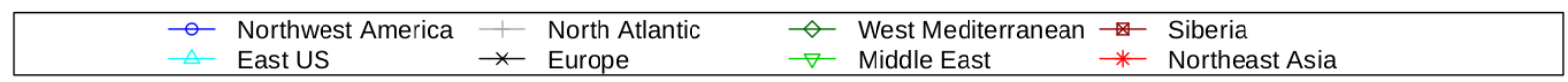

Figure 6. Mean seasonal cycles of $\mathrm{O}_{3}, \mathrm{CO}$, and $\mathrm{O}_{3} / \mathrm{CO}$ (from left to right) in the upper troposphere, tropopause layer, and lower stratosphere (from bottom to top).

The $\mathrm{O}_{3}$ summertime maxima observed above most regions in the UT are driven by strong photochemical activity, consistent with the $\mathrm{O}_{3} / \mathrm{CO}$ seasonal cycles (Fig. 6i). As shown in Fig. 7c, these $\mathrm{O}_{3}$ maxima are significant for the whole monthly distribution. Stratmann et al. (2016) used the IAGOS-CARIBIC data set to compute a climatology for nitrogen oxides and reactive nitrogen species $\left(\mathrm{NO}_{y}\right)$ from 2005 until 2013, with the same definition for the UT. The regions they defined as Europe and North Atlantic are the most sampled ones in the CARIBIC data set, which allows us to compare the seasonal cycles they derived in these regions with ours. Their study is based on larger regions than the ones we defined. Still, they derived upper-tropospheric $\mathrm{NO}$ and $\mathrm{NO}_{y}$ maxima well correlated with the $\mathrm{O}_{3}$ maxima from our study. It is consistent with the leading role of photochemistry in the summertime $\mathrm{O}_{3}$ maximum, at least in these two regions. Furthermore, Gressent et al. (2014) highlighted the influence of springtime and summertime lightning activity, warm conveyor belts, and convection over North America on the $\mathrm{O}_{3}$ enhancement in the UT over North Atlantic and Europe from 2001 to 2005.

Beside these general features, the following subsections highlight significantly different seasonal characteristics.

\subsubsection{Northeast Asia, northwest America, and Siberia}

The CO seasonal cycle in the UT over northeast Asia is different from the others (Fig. 8). Among all the regions, northeast Asia shows the highest mixing ratio during MaySeptember. Its CO maximum ranges up to $140 \mathrm{ppb}$ and lasts from April to June, in contrast to the April climatological mean from most regions of around $120 \mathrm{ppb}$. It is characterized by the seasonal maximum in the 95th percentile during the same months. The high values in April are likely due to a strong wintertime $\mathrm{CO}$ accumulation in the lower troposphere (Zbinden et al., 2013), strong springtime agricultural fire emissions (Tereszchuk et al., 2013), and boreal biomass burning emissions (Andela et al., 2013). The high values in June can be associated with anthropogenic and biomass burning emissions coupled with geographically more frequent warm conveyor belts (e.g. Madonna et al., 2014; Nédélec et al., 2005) and summertime Asian convection (Huang et al., 2016). A peak is found in June in the TPL, too, and in the LS to a lesser extent. High summertime $\mathrm{CO}$ mixing ratios are also observed over eastern Asia by MLS observations at $215 \mathrm{hPa}$ (Huang et al., 2016), slightly above the TPL. 
$\mathrm{O}_{3}$ seasonal cycles (Jan. 1995 - Dec. 2013)

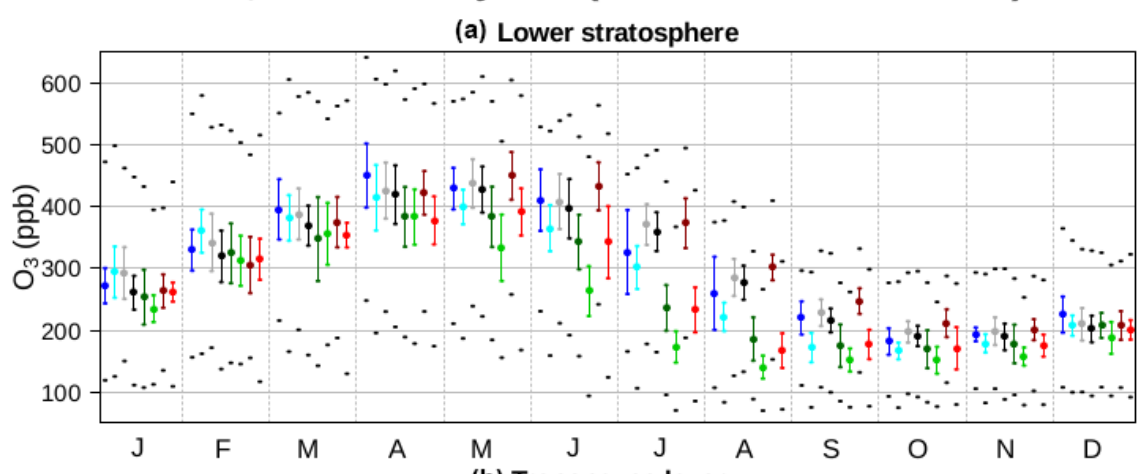

(b) Tropopause layer

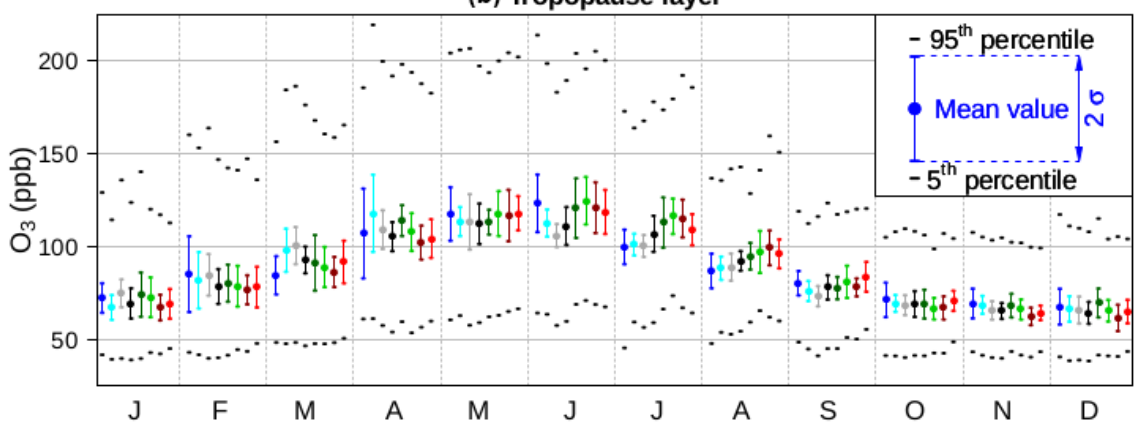

(c) Upper troposphere

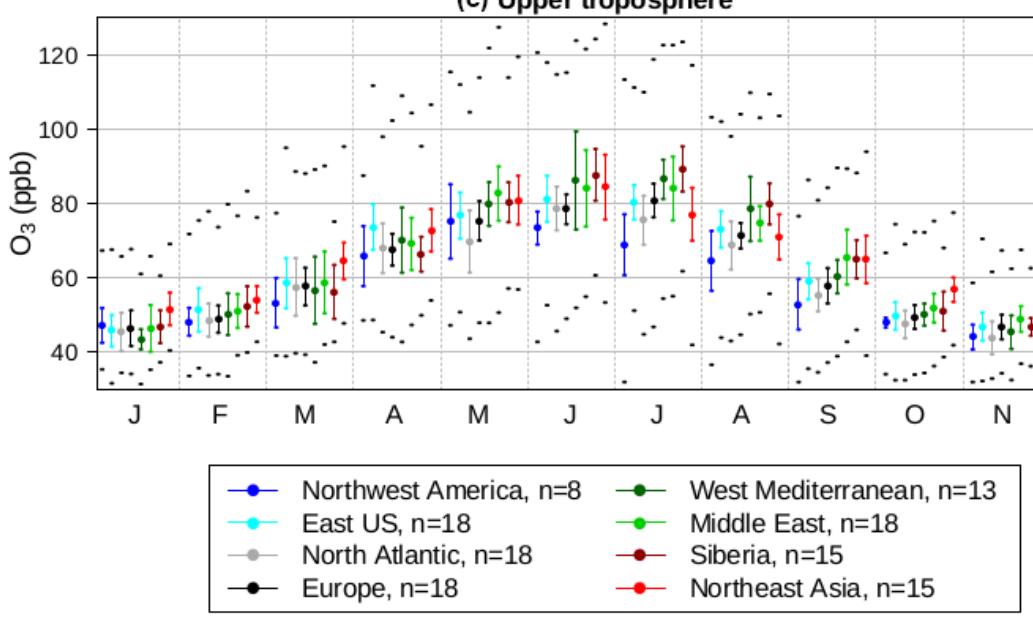

Figure 7. Seasonal cycles of $\mathrm{O}_{3}$ for the monthly mean value (coloured points) and the 5th and 95th percentiles (lower and upper black ticks respectively). The interannual variability (coloured error bars) corresponds to the interannual standard deviation of the monthly mean value $\sigma$. From bottom to top, the graphs represent the cycles in the upper troposphere, tropopause layer, and lower stratosphere. The amount of years taken into account in the calculation of the upper-tropospheric $\mathrm{O}_{3}$ cycles is indicated in the bottom legend as the number $n$.

Mean upper-tropospheric CO in Siberia shows a levelling off from February until June and peaks in July, like the 95th percentile. This last feature is consistent with the Global Fire Emissions Database (GFED3: van der Werf et al., 2010) and the Global Fire Assimilation System (GFASv1.0: Kaiser et al., 2012) inventories for CO emissions from Asian boreal forest fires (Andela et al., 2013). Since the peak is noticeable in the TPL too, it suggests a non-negligible impact of pyroconvection (Tereszchuk et al., 2013).
In contrast to the other regions, the upper-tropospheric $\mathrm{O}_{3}$ seasonal cycle in northwest America does not exhibit a summertime maximum (Fig. 7). By contrast, the seasonal pattern shared with the other regions breaks in June and July, with mean values approximately $10 \mathrm{ppb}$ lower on average. Northeast Asia is also affected by an early decrease in July. These two Pacific-coast regions show an early decrease in the seasonal cycles of the 5th percentile too, down to very low values in July: 32 and 42 ppb. Meanwhile, the 5th percentile averaged among the other regions reaches $53 \mathrm{ppb}$. 


\section{CO seasonal cycles (Jan. 2002 - Dec. 2013)}

(a) Lower stratosphere
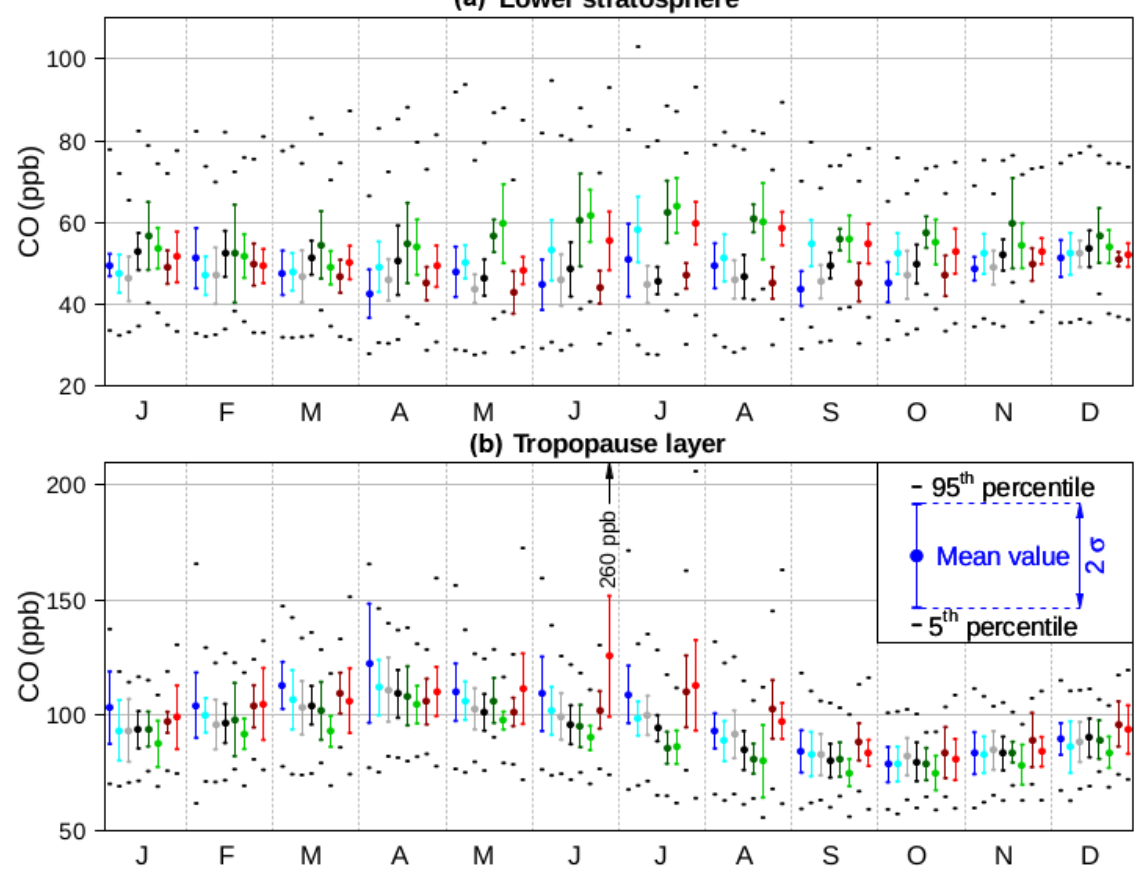

(c) Upper troposphere

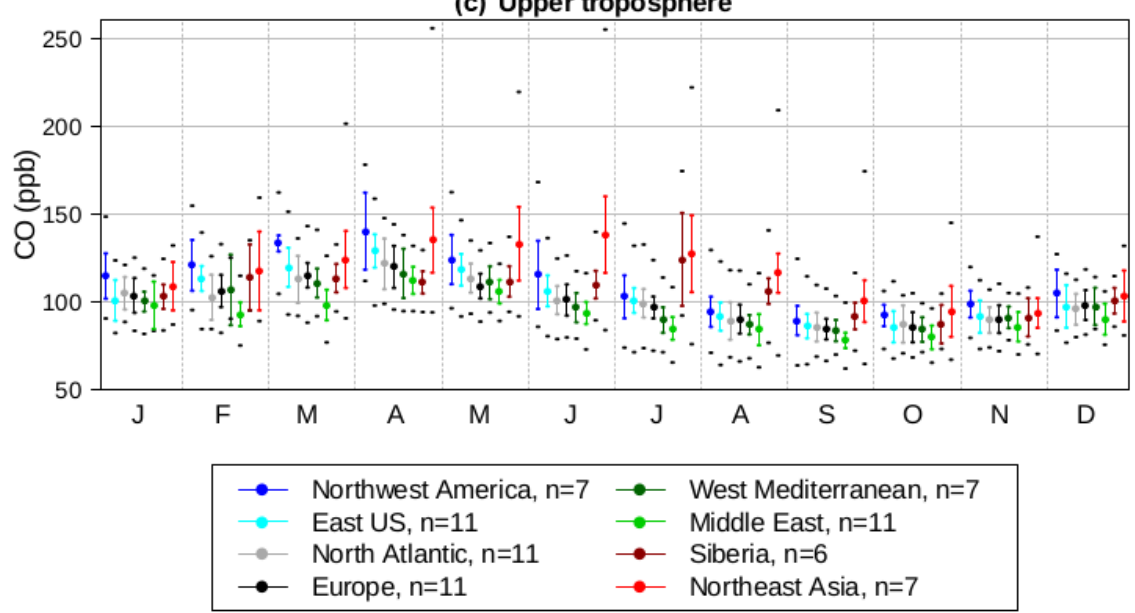

Figure 8. Seasonal cycles of CO for the monthly mean value (coloured points) and the 5th and 95th percentiles (lower and upper black ticks respectively). The interannual variability (coloured error bars) corresponds to the interannual standard deviation of the monthly mean value $\sigma$. From bottom to top, the graphs represent the cycles in the upper troposphere, tropopause layer, and lower stratosphere. The amount of years taken into account in the calculation of the upper-tropospheric $\mathrm{CO}$ cycles is indicated in the bottom legend as the number $n$.

This is consistent with the study of Zbinden et al. (2013), which highlights that the free troposphere above Los Angeles $\left(118.17^{\circ} \mathrm{W}, 34.00^{\circ} \mathrm{N}\right)$ and the Japanese airports visited (Osaka, Nagoya, Tokyo; approximately $35^{\circ} \mathrm{N}, 138^{\circ} \mathrm{E}$ ) is influenced by a seasonal change in wind directions. During summer, the Asian monsoon and the North American monsoon contribute to $\mathrm{O}_{3}$-poor air masses from the subtropical $\mathrm{Pa}$ cific Ocean. Lidar measurements over TMF during summer in 2013-2014 also showed the influence of these air masses, notably between 9 and $12 \mathrm{~km}$ a.s.l. (Granados-Muñoz et al.,
2017). It is worth noting that despite the common characteristics with TMF, the northwest America region is located above $40^{\circ} \mathrm{N}$. Thus, in contrast to TMF, northwest America may not be impacted by the rich- $\mathrm{NO}_{x}$ air masses originating from Central America (Cooper et al., 2009, Fig. 7), where a strong summertime lightning activity and the North American monsoon anticyclone allow the build-up of a recurrent maximum in $\mathrm{O}_{3}$ in the UT (e.g. Cooper et al., 2007). Cooper et al. $(2007,2009)$ also showed the impact of midlatitudinal Eurasian emissions on free-tropospheric $\mathrm{O}_{3}$ above several 
American sites, potentially representative of the northern part of the northwest America region. This could explain the fact that the summertime 95th percentile in $\mathrm{O}_{3}$ (Fig. 7) is similar to the other regions, despite the absence of nearby sources upwind and the more frequent clean tropical air masses. It is consistent with the strong 95th percentile for $\mathrm{CO}$ in northwest America (Fig. 8), correlated with the one from northeast Asia, suggesting that these two regions have common upwind strong emissions. It is weaker in northwest America than in northeast Asia, highlighting the decrease in $\mathrm{CO}$ mixing ratio during the long-range transport, probably due to dilution and photochemistry. In Fig. 9, the springtime and summertime $\mathrm{O}_{3} / \mathrm{CO}$ ratios in the UT exhibit lower values (0.60.7) in these two Pacific-coast regions compared to the other locations (at least 0.1 higher). These lower values are mainly characterized by a lower 5 th percentile (0.4), consistent with a higher frequency of high- $\mathrm{CO}$ and $\mathrm{O}_{3}$-poor air masses. However, in contrast to ozone, the seasonal cycles of the $\mathrm{O}_{3} / \mathrm{CO}$ ratio do have a summer maximum. The interruption observed in the $\mathrm{O}_{3}$ seasonal cycles thus remains characterized by the summer maximum in photochemical activity, despite the fast change in the monthly air composition.

Interestingly, in the UT, northwest America shows one of the lowest mean springtime $\mathrm{O}_{3}$ mixing ratios too, linked to the upper values (see the low P95 during March-April in Fig. 7), whereas its mean springtime $\mathrm{CO}$ is the highest (Fig. 8). This last feature is characterized by a distribution shifted toward the upper values, compared to the other regions, as for the $\mathrm{O}_{3} / \mathrm{CO}$ ratio. The lower $\mathrm{P} 95$ in $\mathrm{O}_{3}$ associated with the stronger P5 in CO during February-April likely indicates that northwest America is less frequently impacted by $\mathrm{O}_{3}$-rich air masses and less frequently impacted by poor-CO air masses. Lower-stratospheric $\mathrm{O}_{3}$ also exhibits the strongest P5 in northwest America, amongst all the regions. Since this feature only occurs during March-April, it is unlikely driven only by the aircraft flight level, relative to the tropopause. Furthermore, the $P_{2}$ pvu averages shown in Fig. 5 are not at lower altitudes during April. Consequently, the stronger P5 in northwest America suggests less frequent tropospheric air masses in the LS during MarchApril. All these features indicate a less efficient springtime stratosphere-troposphere exchange in northwest America.

\subsubsection{The Western Mediterranean basin and the Middle East}

As expected in Fig. 7 (Fig. 8), the mean $\mathrm{O}_{3}$ (CO) concentrations in the LS are lower (higher) in the Western Mediterranean basin, the Middle East, and northeast Asia, which are the southernmost regions of this study. Indeed, as the dynamical tropopause is generally higher there (Fig. 5), although the flights are classified as LS, they are likely to sample air masses closer to the tropopause: the substantial difference in $\mathrm{O}_{3}$ mixing ratios is thus explained by its strong vertical gradient in the stratosphere. During July-August, three cate- gories of regions can be established depending on the width of the monthly distribution of the $\mathrm{O}_{3} / \mathrm{CO}$ ratio. Referring to Fig. 9, the northernmost regions (northwest America, the North Atlantic, Europe, Siberia) exhibit a higher $\mathrm{O}_{3} / \mathrm{CO}$ ratio for all three metrics (mean value and 5th and 95th percentiles). By contrast, the southernmost regions (the Western Mediterranean basin, the Middle East, and northeast Asia) show a lower ratio, for all three metrics again. The remaining region (the eastern United States) shows a strong intramonthly variability with a low 5 th percentile, an intermediate mean value, and a high 95th percentile. These categories thus correspond respectively to regions mostly impacted by extratropical air masses, to regions strongly impacted by subtropical air masses, and to the region influenced by both extratropical and subtropical air masses. In June, northeast Asia belongs to this intermediate category with its low 5th and high 95th percentiles before reaching the subtropically influenced regions in July.

In summer, $\mathrm{CO}$ mixing ratios are similar over the Western Mediterranean basin and the Middle East, but Middle East $\mathrm{O}_{3}$ is significantly lower. This feature is consistent with the mixing ratios derived from OMI-MLS observations at $150 \mathrm{hPa}$ presented in Park et al. (2007) and at $100 \mathrm{hPa}$ in Park et al. (2009). In southern Asia, polluted surface air masses are uplifted by deep convection during the Asian monsoon, up to the tropical UT. The western part of the anticyclonic circulation then transports $\mathrm{O}_{3}$-poor air masses northward and horizontally (Barret et al., 2016). This may impact the LS in the Middle East (Park et al., 2007), consistent with $\mathrm{CH}_{4}$ measurements from IASI and AIRS, coupled with modelling using the CNRM-AOCCM, LMDzOR-INCA chemistry-climate models and the MOCAGE chemistry-transport model (Ricaud et al., 2014). The summertime lower-stratospheric CO mixing ratio is comparable between the Western Mediterranean basin, the Middle East, and northeast Asia. The last one is impacted by frequent warm conveyor belts coupled with strong fire activity (Madonna et al., 2014; Jiang et al., 2017).

In the UT, there is more $\mathrm{O}_{3}$ and less $\mathrm{CO}$ in the Western Mediterranean basin and the Middle East. Figure 9 better illustrates the distinction of these two regions from the others, with a high $\mathrm{O}_{3} / \mathrm{CO}$ ratio. Its mean value reaches 0.95 in July in the two regions in the UT and is both characterized by higher 5 th and 95 th percentiles. Note that $\mathrm{O}_{3} / \mathrm{CO}$ is also higher in the TPL $(\simeq 1.5)$. All these features show the impact of the stronger summertime subsidence at these latitudes on the whole monthly distribution in the UT. In the Middle East particularly, Etesian winds interact with the Asian Monsoon Anticyclone (AMA), enhancing the subsidence of high-level air masses (e.g. Tyrlis et al., 2013), thus allowing a recurrent summertime $\mathrm{O}_{3}$ pool down to the mid-troposphere (Zanis et al., 2014). 


\section{$\mathrm{O}_{3} /$ CO seasonal cycles (Jan. 2002 - Dec. 2013)}
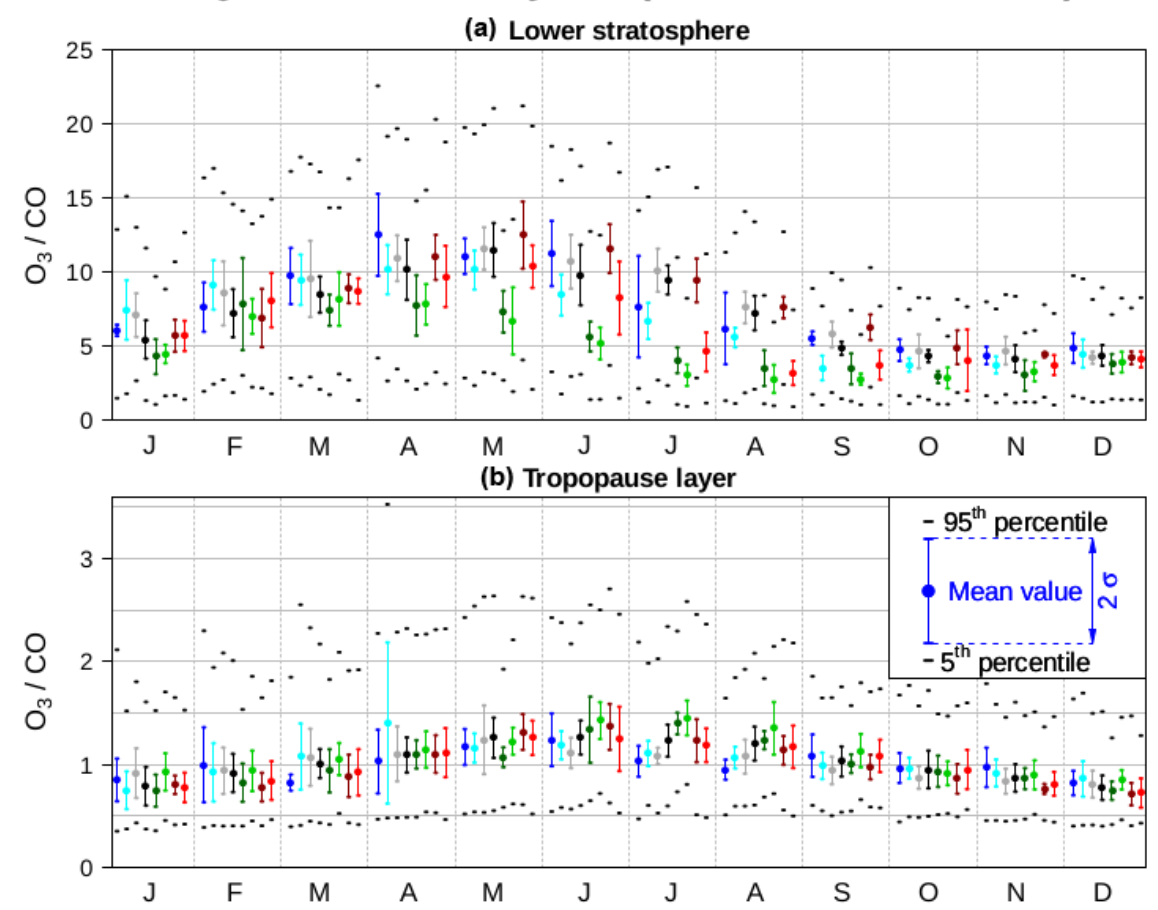

(c) Upper troposphere

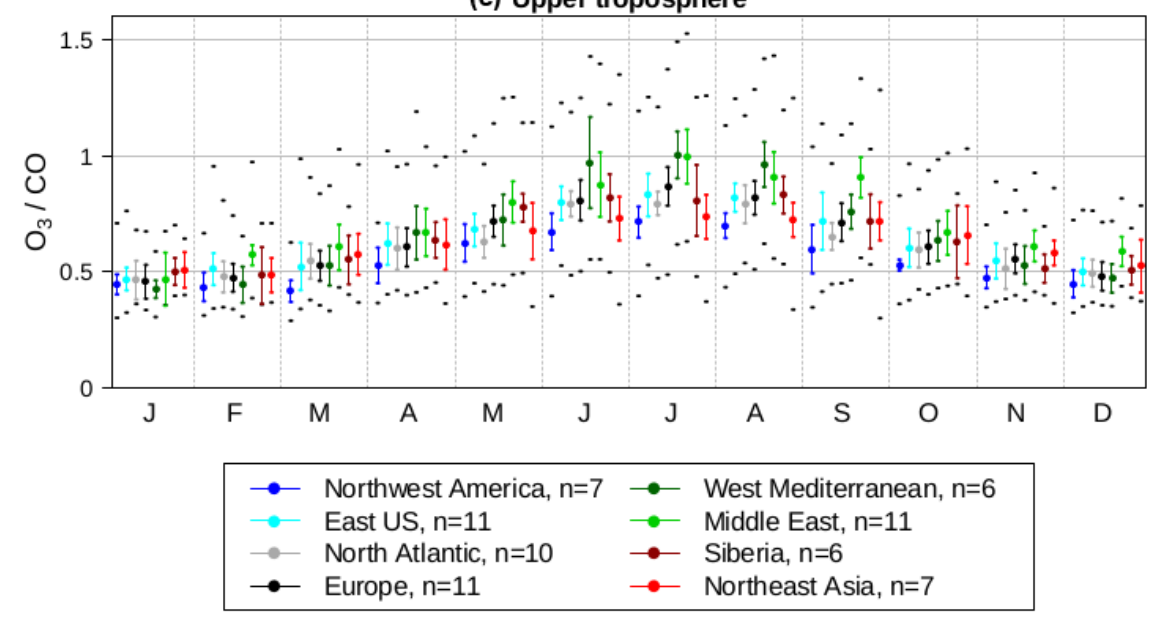

Figure 9. Seasonal cycles of the $\mathrm{O}_{3} / \mathrm{CO}$ ratio for the monthly mean value (coloured points) and the 5th and 95th percentiles (lower and upper black ticks respectively). The interannual variability (coloured error bars) corresponds to the interannual standard deviation of the monthly mean value $\sigma$. From bottom to top, the graphs represent the cycles in the upper troposphere, tropopause layer, and lower stratosphere. The amount of years taken into account in the calculation of the upper-tropospheric $\mathrm{O}_{3} / \mathrm{CO}$ cycles is indicated in the bottom legend as the number $n$.

\subsection{Trends: comparison and characterization}

In this section, annual and seasonal trends of $\mathrm{O}_{3}$ and $\mathrm{CO}$ are investigated in the different regions (see Sect. 2.2.2 for details on the calculations of trends), from August 1994 until December 2013 for $\mathrm{O}_{3}$ and from December 2001 until December 2013 for CO. For a more complete description of the data set, the corresponding time series for both species are given for the three layers in Figs. B1-B6.
As shown in these figures, no monthly data are available during most of 2010, due to an interruption of measurements. Most regions have a good sampling efficiency, with about $70-97 \%$ of available data (see Table 1). Specifically, the lower sampling frequency in northwest America (top-left panel) allows relatively few available monthly data. For $\mathrm{O}_{3}$, the sampling focuses on the period 2003-2009. Since less than $60 \%$ of monthly data are available, and since the available months are especially representative of the second half 
(a) LS, 5th percentile

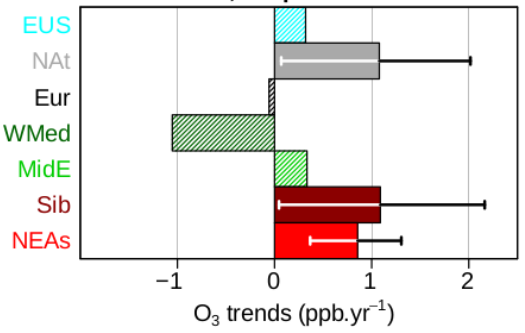

(d) TPL, 5th percentile

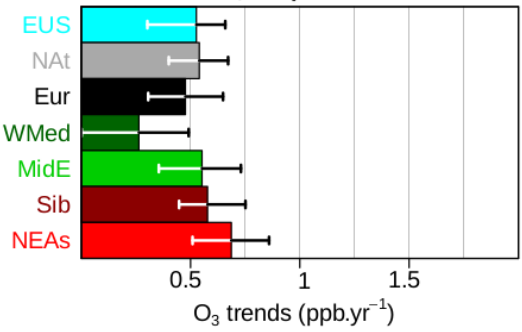

(g) UT, 5th percentile

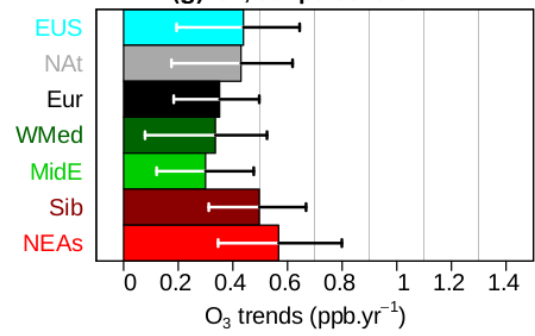

(b) LS, mean value

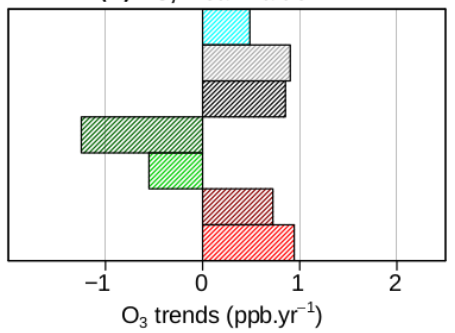

(e) TPL, mean value

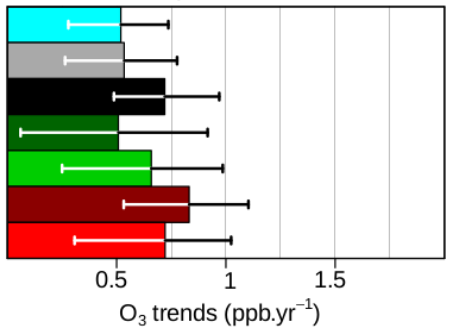

(h) UT, mean value

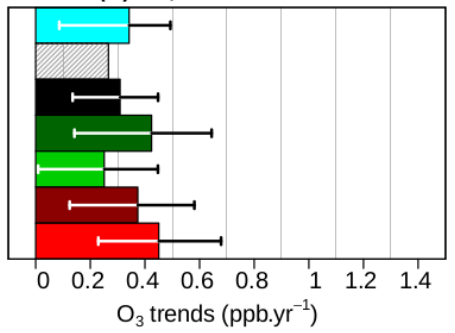

(c) LS, 95th percentile

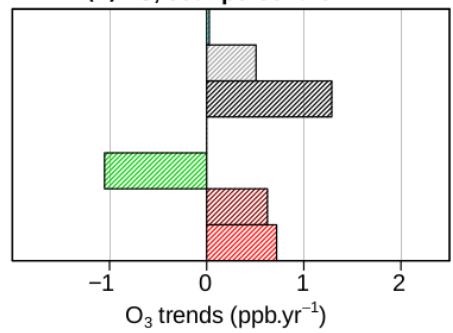

(f) TPL, 95th percentile

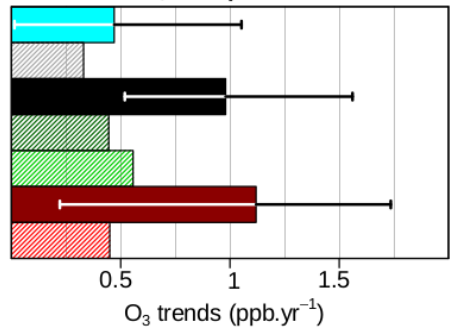

(i) UT, 95th percentile

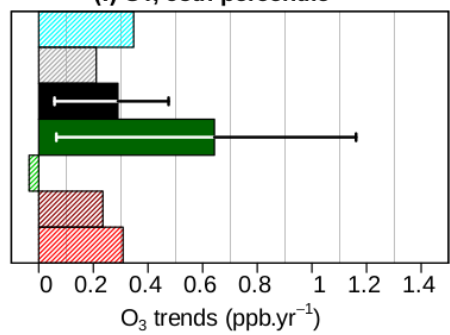

Figure 10. $\mathrm{O}_{3}$ trends $\left(\mathrm{ppb} \mathrm{yr}^{-1}\right.$ ) in the UT, TPL, and LS (from bottom to top) for the monthly 5th percentile (a, d, $\mathbf{g}$ ), mean value (b, e, h), and 95th percentile (c, f, i). For each significant trend, the error bars represent the $95 \%$ confidence interval. The insignificant trends are represented by hatched areas. The coloured labels correspond to the regions defined in Fig. 1.

of the monitoring period, we cannot take it into account in the study of the 20-year trends. After 2009, the sampling is efficient only during winter, such that we can only compute the trend of wintertime $\mathrm{CO}$ in this region. The sampling is also too low for $\mathrm{CO}$ in the Western Mediterranean basin in the LS (55\%). In Siberia, northeast Asia, and the Western Mediterranean basin (excluding the LS for this region), the sampling is moderate for $\mathrm{CO}$ (between 60 and $70 \%$ ) but data are available both at the beginning and at the end of the period, which makes trends calculations still relevant.

For additional information, the monthly relative anomalies we used for the trends calculations are shown in Figs. C1-C4.

In the UT, the anomalies have several common features: a negative anomaly until 1997, followed by a levelling off during 2000-2009 and then by a positive anomaly since 2011 . The first period (1994-1997) has already been associated with the multi-year ozone recovery since the eruption of Mt Pinatubo in 1991: this event was an important source of particulate matter in the lower stratosphere at a global scale, contributing to the ozone depletion in the UT, TPL, and LS (e.g. Tang et al., 2013). The positive anomaly in 1998 has been referenced as a consequence of the extreme El Niño event in
1997, as explained in Thouret et al. (2006) and Koumoutsaris et al. (2008).

The LS does not show such a positive anomaly at the end of the period nor the same interannual variability. We can note the positive anomalies in 2006 in northwest America, Europe, and Siberia. It seems consistent with the downward $380 \mathrm{~K}$ ozone flux anomalies shown in Olsen et al. (2013, Fig. 5).

\subsubsection{Trends in $\mathrm{O}_{3}$}

$\mathrm{O}_{3}$ trends are summarized in Figs. 10 and 11. Figure 10 shows the trends of monthly 5 th percentiles, mean values, and 95th percentiles for $\mathrm{O}_{3}$, in the left, central, and right panels respectively. Figure 11 shows the trends of the $\mathrm{O}_{3}$ mean value in the UT, with respect to the season. In parallel, the absolute trends are reported in Tables D1 and D2 with their corresponding confidence intervals, in Appendix D. Note that all confidence intervals in this paper are given at the $95 \%$ level. For a better precision, we use the values reported in this table to comment on the following figures. The relative trends (in $\% \mathrm{yr}^{-1}$ ) are also reported in Tables D3 and D4 in order to facilitate the comparison with other data sets. For clarity, 

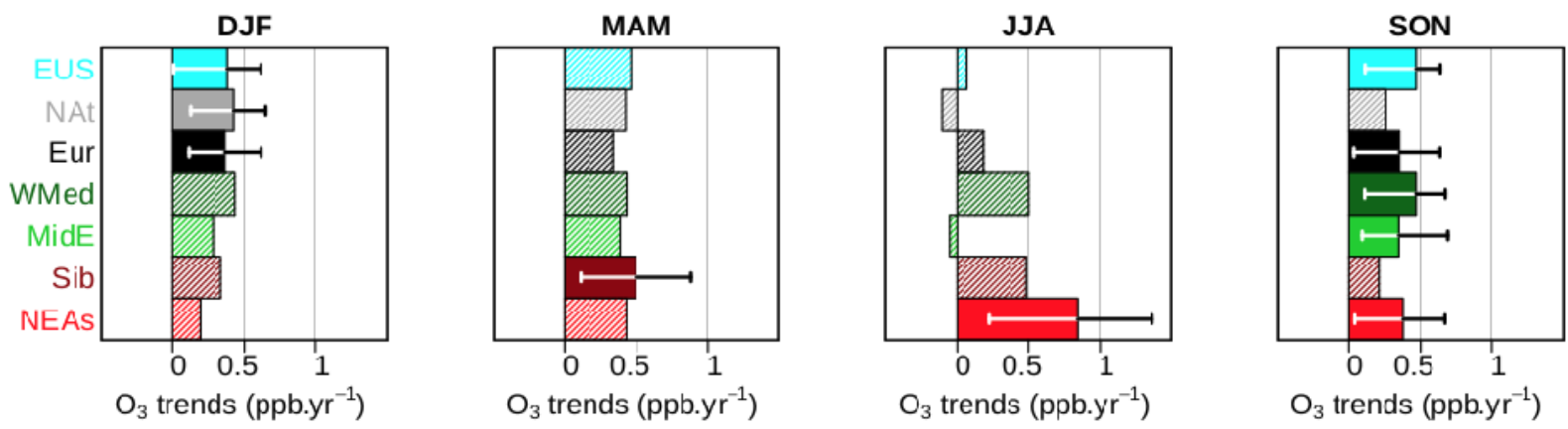

Figure 11. $\mathrm{O}_{3}$ trends $\left(\mathrm{ppb} \mathrm{yr}^{-1}\right)$ in the UT, in each season. For each significant trend, the error bars represent the $95 \%$ confidence interval. The insignificant trends are represented by hatched areas. The coloured labels correspond to the regions defined in Fig. 1.

only the significant trends at the $95 \%$ confidence level are reported.

At the annual scale, mean upper-tropospheric $\mathrm{O}_{3}$ significantly increases in the seven regions except the North Atlantic, with trend estimates ranging from +0.25 up to $+0.45 \mathrm{ppb} \mathrm{yr}^{-1}$. The strongest and most significant trend is found in northeast Asia, with $+0.45[0.23 ; 0.68] \mathrm{ppb} \mathrm{yr}^{-1}$. The least significant trend concerns the Middle East $(+0.25$ $\left.[0.01 ; 0.45] \mathrm{ppb} \mathrm{yr}^{-1}\right)$. The trends in the TPL are similar to the upper-tropospheric trends, albeit stronger and generally with a better significance. On the other hand, all mean $\mathrm{O}_{3}$ trends remain insignificant in the LS.

On one hand, quite similar results are obtained for the $\mathrm{O}_{3}$ 5th percentile in the UT and TPL. Again, the strongest increase in the UT is observed in northeast Asia $(+0.57[0.35$; $\left.0.80] \mathrm{ppb} \mathrm{yr}^{-1}\right)$, closely followed by Siberia $(+0.50[0.31$; 0.67] $\mathrm{ppb} \mathrm{yr}^{-1}$ ). The Atlantic regions (the eastern United States, the North Atlantic, and Europe) exhibit an intermediate significance, with a stronger increase at approximately $+0.45 \mathrm{ppb} \mathrm{yr}^{-1}[0.20 ; 0.65]$ in the eastern United States and the North Atlantic. The small southern regions (the Western Mediterranean basin and the Middle East) show the lowest and least significant increase at $+0.34[0.08 ; 0.52]$ and $+0.30[0.12 ; 0.48] \mathrm{ppb} \mathrm{yr}^{-1}$ respectively. The main difference with the $\mathrm{O}_{3}$ mean value is found in the LS where a significant positive trend occurs in a few regions (North Atlantic, Siberia, northeast Asia). On the other hand, the upper-tropospheric P95 increases significantly in Europe and the Western Mediterranean basin only, at +0.29 [0.06; $0.47] \mathrm{ppb} \mathrm{yr}^{-1}$ and $+0.64[0.06 ; 1.16] \mathrm{ppb} \mathrm{yr}^{-1}$ respectively, with $p$ values higher than 0.02 indicating a low significance level. In the TPL, the increase is observed in the eastern United States, Europe, and Siberia, while no significant trend is found in the LS. Therefore, the general positive trend of mean $\mathrm{O}_{3}$ mixing ratios in both the UT and TPL is associated with an increase in the background values (represented by the 5 th percentile). The Western Mediterranean basin may be an exception with its strong increase in P95, contributing as well to the strong positive trend in the mean value.
The $\mathrm{O}_{3}$ seasonal trends in the UT are shown in Fig. 11. As a main result, we note that each region shows a significant positive trend only during specific seasons. A significant increase of $\sim 0.5 \mathrm{ppb} \mathrm{yr}^{-1}$ is observed in the Atlantic regions (the eastern United States, the North Atlantic, and Europe) in winter, with a non-negligible significance in the North Atlantic and Europe. Only Siberia shows a significant increase during spring $\left(0.50 \mathrm{ppb} \mathrm{yr}^{-1}\right)$, as does northeast Asia during summer $\left(0.84 \mathrm{ppb} \mathrm{yr}^{-1}\right)$. Most of the regions show a significant increase during fall. The 5th percentile of $\mathrm{O}_{3}$ mixing ratios is increasing in most regions during winter and spring. The strongest P05 trend is observed during summertime in northeast Asia $\left(+1.07[0.58 ; 1.42] \mathrm{ppb} \mathrm{yr}^{-1}\right)$. Concerning the 95th percentile of $\mathrm{O}_{3}$, all trends remain insignificant, except in Europe during winter $\left(+0.43[0.10 ; 0.88] \mathrm{ppb} \mathrm{yr}^{-1}\right)$.

The upper-tropospheric $\mathrm{O}_{3}$ trends are also computed over several periods, in order to test the sensitivity of our results to the start and the end of the monitoring period. They are shown in Fig. 12 for the three metrics (mean value and 5 th and 95th percentiles). The trends over the whole period are compared to the ones computed over 1994-2008, thus excluding the last 3 years' positive anomalies, and to the ones computed over 2002-2013, i.e. the monitoring period for $\mathrm{CO}$. Removing the last years' positive anomaly leads to the loss of the $2 \sigma$ statistical significance for most significant trends in three regions for the 5th percentile (North Atlantic, the Western Mediterranean basin, the Middle East), four regions for the mean value (the eastern United States, the Western Mediterranean basin, the Middle East, Siberia), and the two only regions for the 95th percentile (Europe, the Western Mediterranean basin). Consequently, the significant increase in the mean $\mathrm{O}_{3}$ mixing ratio shown in Fig. 10 is robust for Europe and northeast Asia, and the significant increase in the 5th percentile is robust also in the eastern USA and Siberia. In the other cases, the $2 \sigma$ confidence interval is strongly sensitive to the higher ozone values during 2001-2013.

On the 2001-2013 period (Fig. 12h) the statistical significance for the mean values is stronger in the Middle East and Siberia and weaker elsewhere compared to the full period. The regions where it decreases also show a weakening 
5th percentile, Aug. 1994 - Dec. 2013

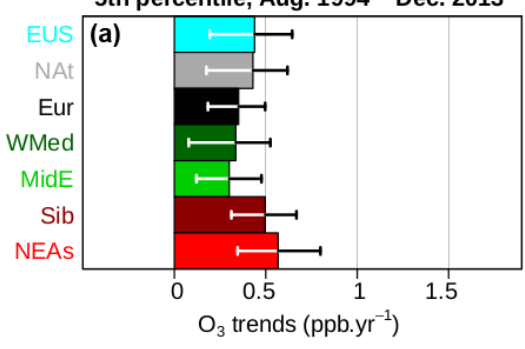

5th percentile, Aug. 1994 - Dec. 2008

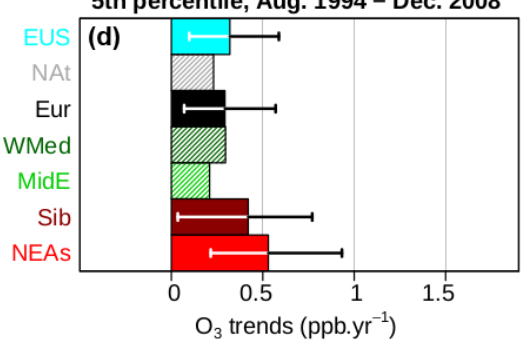

5th percentile, Dec. 2001 - Dec. 2013

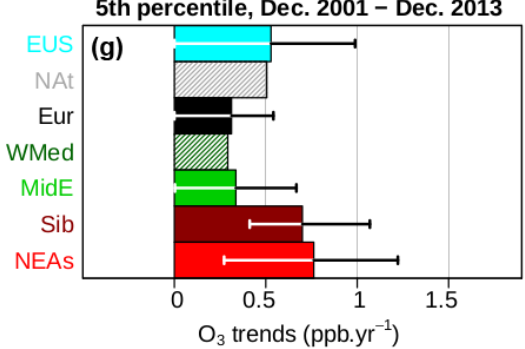

Mean value, Aug. 1994 - Dec. 2013

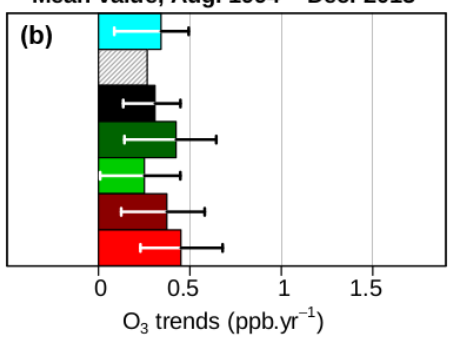

Mean value, Aug. 1994 - Dec. 2008

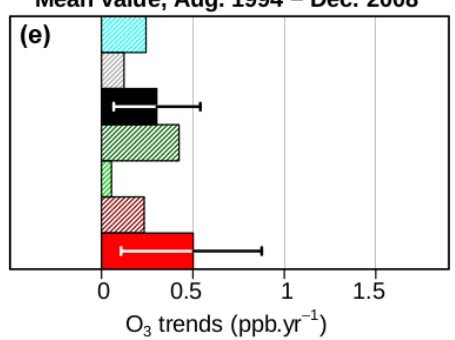

Mean value, Dec. 2001 - Dec. 2013

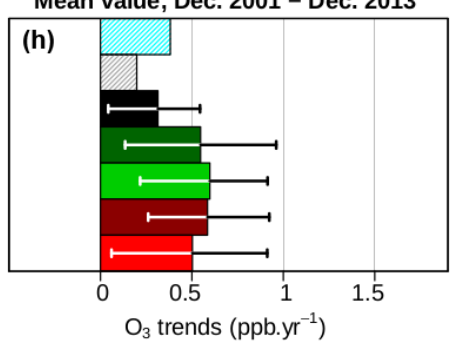

95th percentile, Aug. 1994 - Dec. 2013

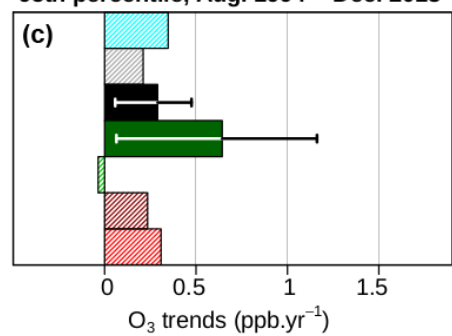

95th percentile, Aug. 1994 - Dec. 2008

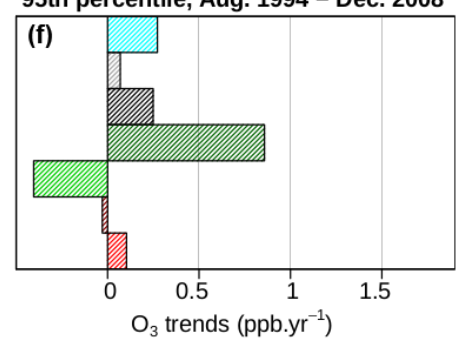

95th percentile, Dec. 2001 - Dec. 2013

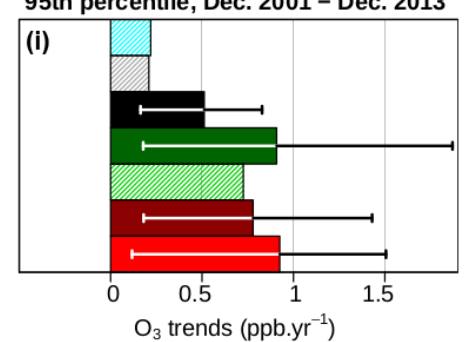

Figure 12. $\mathrm{O}_{3}$ trends $\left(\mathrm{ppb} \mathrm{yr}^{-1}\right.$ ) in the UT over the whole monitoring period (1994-2013: a-c), over 1994-2008 (d-f), and over the monitoring period for CO (2002-2013: g-i) for the monthly 5th percentile (a, d, g), mean value (b, e, h), and 95th percentile (c, f, i). For each significant trend, the error bars represent the $95 \%$ confidence interval. The insignificant trends are represented by hatched areas. The coloured labels correspond to the regions defined in Fig. 1.

in the significance of the 5th percentile. The trends in 95th percentiles (Fig. 12c, f, i) appear to be limited by the first years. Thus, this shows a transition between the first part and the last part of the monitoring period, highlighted by a change in the trends in the monthly distribution. The uppertropospheric $\mathrm{O}_{3}$ trends are higher during 2002-2013 because of the positive anomaly at the end of this period. One possible explanation for this anomaly lies in an enhanced transport across the tropopause caused by the 2009-2010 strong El Niño event, as shown in Lin et al. (2015). Responses in tropospheric ozone at the midlatitudes to the El Niño Southern Oscillation (ENSO) have been identified in Wespes et al. (2017) with a 4-month or 6-month time lag. Further modelling studies are needed to assess the link between the chemical composition of the upper troposphere and the ENSO.

It is worth noting that besides the IAGOS database, in situ observations are very sparse in the UTLS and their time coverage is usually too short for determining long-term trends. This considerably limits our ability to compare these results to the literature. As mentioned in Sect. 1, the IAGOS measurements during 1994-2003 showed significant positive trends for ozone mixing ratios above the eastern
United States, the North Atlantic, and Europe in the UT (respectively, $+0.99 \pm 0.82 \% \mathrm{yr}^{-1},+1.12 \pm 0.86 \% \mathrm{yr}^{-1}$, and $\left.+1.00 \pm 0.90 \% \mathrm{yr}^{-1}\right)$ and the LS $\left(+1.54 \pm 1.37 \% \mathrm{yr}^{-1}\right.$ above North Atlantic and $+1.99 \pm 1.21 \% \mathrm{yr}^{-1}$ above Europe) (Thouret et al., 2006). With a new decade of observations, our results suggest that the previous trends in the LS were influenced by the low values from 1994 until 1997, following the Pinatubo eruption. More recently, Petetin et al. (2016) used IAGOS measurements to study vertical profiles of $\mathrm{O}_{3}$ and $\mathrm{CO}$ above Frankfurt and Munich airports, during similar periods. As in Thouret et al. (2006), they defined the UT with the same method. In this layer, they found a barely significant increase in $\mathrm{O}_{3}$ during winter. At the annual scale, they derived a significant positive trend of $\mathrm{P} 5$, consistent with our results. However, they did not observe the $99 \%$ significant positive trend of $\mathrm{P} 95$ that we derived $\left(+0.4 \mathrm{ppb} \mathrm{yr}^{-1}\right.$, $p=8 \times 10^{-3}$ ?). Since we compute the trends with the same methodology, the discrepancies are due to the greater size of our Europe region, which allows a higher amount of data and thus a more significant statistical analysis.

In terms of $\mathrm{O}_{3}$ trends in the free troposphere (rather than the UT), many studies highlighted increasing mixing ratios 
over time. Based on a combined data set (MOZAIC, research aircraft, ozonesondes, lidar) over western North America $\left(25-55^{\circ} \mathrm{N}, 130-90^{\circ} \mathrm{W}\right)$, Cooper et al. (2010) derived an increase in springtime $\mathrm{O}_{3}$ (April-May) in the UT over the period 1995-2008 $\left(+0.58 \pm 0.52 \mathrm{ppb} \mathrm{yr}^{-1}\right.$ for the median $\mathrm{O}_{3}$ ). Over the period 2000-2015, Granados-Muñoz and Leblanc (2016) derived a positive trend from lidar measurements above TMF at $7-10 \mathrm{~km}$, with $+0.31 \pm 0.30 \mathrm{ppb} \mathrm{yr}^{-1}$ for the median (the trend of the 95th percentile being $+0.55 \pm 0.60 \mathrm{ppbyr}^{-1}$, thus significant at the $90 \%$ confidence level only). Based on ozonesondes over the period 1995-2008, Logan et al. (2012) did not observe any significant increase in $\mathrm{O}_{3}$ mixing ratios between 400 and $300 \mathrm{hPa}$ in Europe. The difference with our results can be partly explained by the fact that the period studied by Logan et al. (2012) does not extend to 2011, the beginning of the strong positive anomaly in upper-tropospheric $\mathrm{O}_{3}$, according to the IAGOS data set (see Fig. B1).

Free and upper-tropospheric ozone trends derived from various instruments were reviewed in Cooper et al. (2014). Significant positive trends over the period 1971-2010 are reported with ozonesonde data in the free troposphere above western Europe and Japan, ranging at $0.1-0.3 \mathrm{ppb} \mathrm{yr}^{-1}$. As mentioned in Sect. 1, the significant positive trends measured at the highest Northern Hemispheric GAW stations (above $2 \mathrm{~km}$ a.s.l.: Zugspitze, Rocky Mountain National Park, Jungfraujoch, Mt Bachelor Observatory, Mt Waliguan) rise between $0.05 \pm 0.04$ and $0.33 \pm 0.05 \mathrm{ppb} \mathrm{yr}^{-1}$. Only the most increasing trends (Rocky Mountain and Jungfraujoch) are within the range of the ones derived in the present study. Among the GAW stations mentioned in Sect. 1, the other ones show a smaller increase. In the free troposphere at $510 \mathrm{hPa}$, although on a shorter timescale (2005-2010), Neu et al. (2014a) derived a positive trend of $\simeq+1 \% \mathrm{yr}^{-1}$ in the $30-50^{\circ} \mathrm{N}$ zonal band, based on TES measurements. Thus, the increase in the $\mathrm{O}_{3}$ mixing ratio is probably more representative of the middle and upper altitude ranges of the free troposphere than its lower part.

As said previously, the trends in the TPL are similar to the upper-tropospheric ones. Since no lower-stratospheric trend is significant at the annual scale, we cannot make any conclusion about the evolution of lower-stratospheric ozone. Our results alone do not allow us to explain these trends in the TPL. However, several studies reported a global, significant increase in the tropopause height during the last decades $\left(-0.05 \mathrm{hPa} \mathrm{yr}^{-1}, p<2 \times 10^{-16}\right.$ ? over the period 1979-2011 with ERA-Interim reanalyses in Škerlak et al., 2014; see also Gettelman et al., 2011, and references therein). Above the regions of this study, the typical vertical gradient of $\mathrm{O}_{3} \mathrm{ob}-$ served in the four upper flight levels (where the gradient is the strongest amongst our data) is about $1 \mathrm{ppb} \mathrm{hPa}^{-1}$ (not shown). According to this yearly mean value, the elevation of the TPL would induce an ozone increase by an order of magnitude below the observed trends. Such an increase in the TPL height is thus unlikely to explain a major part of the positive trends in the TPL.

Gettelman et al. (2010) combined a multimodel analysis to derive $\mathrm{O}_{3}$ positive trends near $0.4 \% \mathrm{yr}^{-1}$ over the century in the extratropical UTLS (Ex-UTLS), relative to the tropopause. It is similar to the trends we derive in the UT, from $0.39 \% \mathrm{yr}^{-1}$ in the Middle East to $0.69 \% \mathrm{yr}^{-1}$ in northeast Asia (see Table D3). The simulations of Gettelman et al. (2010) did not show any dependence on tropospheric hydrocarbon chemistry. They concluded that there was an enhanced Brewer-Dobson circulation, which can contribute to the $\mathrm{O}_{3}$ trends we observed in the UT and the TPL. This might explain the springtime positive trends we found in the TPL of the North Atlantic, Europe, Siberia, and northeast Asia, but these trends do not occur specifically during spring. Furthermore, only Siberia shows a springtime significant increase in the UT.

The impact of the sampling density on the observed longterm evolution has been tested by computing the trends of the three most sampled regions with the time coverage of the less sampled regions. With the sampling periods of the Western Mediterranean basin and Siberia, the changes for the eastern United States, the North Atlantic, and Europe were small compared to the confidence intervals $\left(0.1 \% \mathrm{yr}^{-1}\right.$ or less). With the sampling periods of northeast Asia, these trends tend to be higher, but the difference remains insignificant $\left(\simeq 0.2 \% \mathrm{yr}^{-1}\right)$.

\subsubsection{Trends in $\mathrm{CO}$}

$\mathrm{CO}$ trends are summarized in Figs. 13 and 14. As for $\mathrm{O}_{3}$, more precise values are given in Tables D5 and D6 with their corresponding $95 \%$ confidence intervals, followed by the equivalent relative trends in Tables D7 and D8, in the Appendix D. Figure 13 shows the trends of the 5th percentile, mean values, and 95th percentile for monthly $\mathrm{CO}$ data on the left, central and right panels respectively. Figure 14 shows the trends of the CO mean value in the UT, with respect to the season. As discussed at the beginning of Sect. 3.3, we do not take the trend in the LS of the Western Mediterranean basin into account. Similarly, only wintertime trends are taken into account in northwest America.

In all layers and almost all regions, the mean $\mathrm{CO}$ mixing ratios are significantly decreasing, with trends ranging between -0.80 and $-2.19 \mathrm{ppb} \mathrm{yr}^{-1}$ in the UT/TPL and between -0.5 and $-0.8 \mathrm{ppb} \mathrm{yr}^{-1}$ in the LS. The lowest and least significant trends are observed in the Middle East (significant only in the TPL, with $-0.8 \mathrm{ppb} \mathrm{yr}^{-1}$ ). In the UT and TPL, the highest trends of mean $\mathrm{CO}$ are observed in northeast Asia $\left(-2.19[-3.33 ;-0.82] \mathrm{ppb} \mathrm{yr}^{-1}\right)$. Results show a similar picture for the 5th percentile, although with usually slightly lower trends. Apart from the Middle East, these trends are very homogeneous among the different regions. The results appear more contrasted for the 95 th percentile. In the UT, a strong negative trend is observed in northeast Asia 

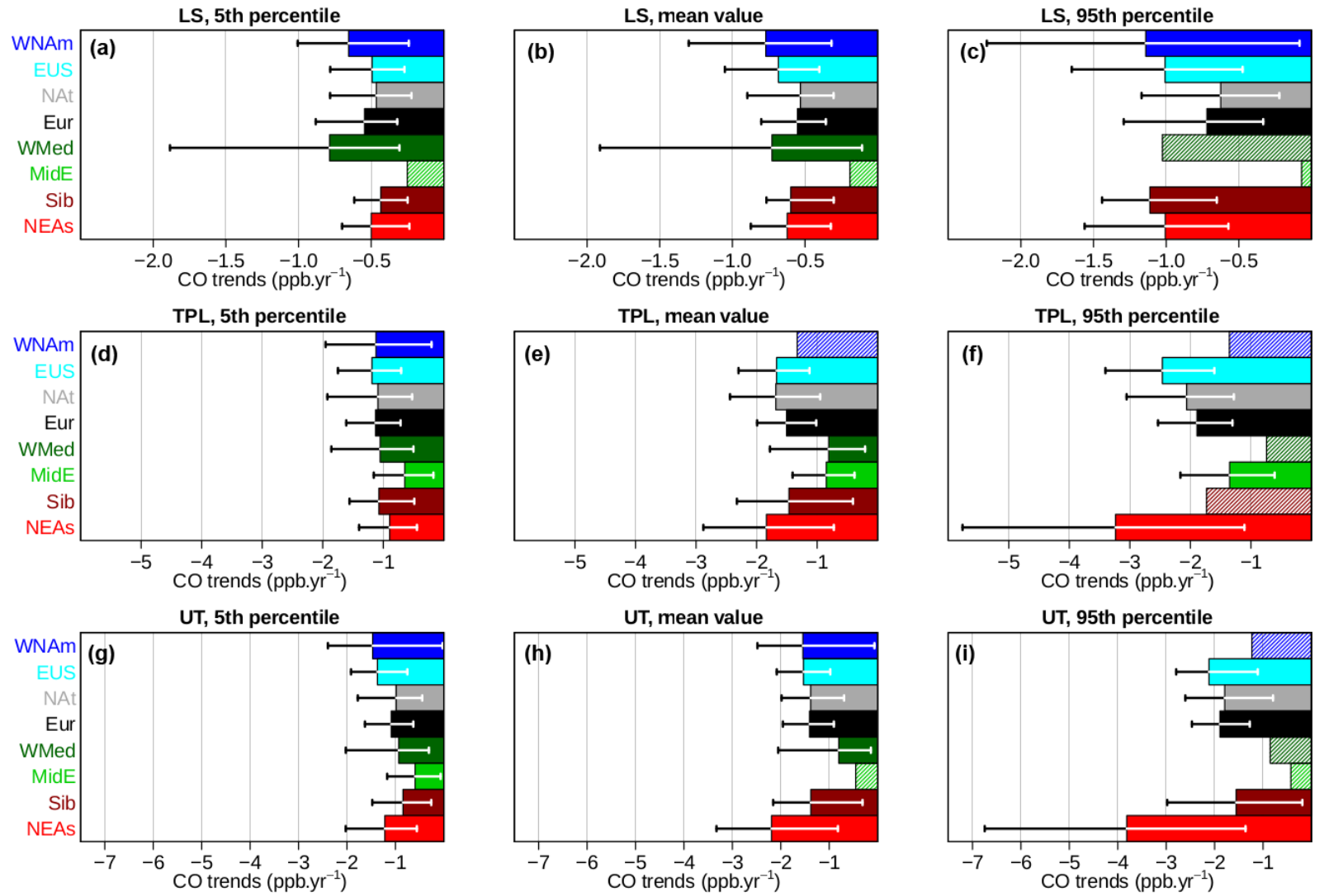

Figure 13. CO trends $\left(\mathrm{ppb} \mathrm{yr}^{-1}\right)$ in the UT, TPL, and LS (from bottom to top) for the monthly 5th percentile (a, d, $\mathbf{g}$ ), mean value (b, e, h), and 95th percentile (c, f, i). For each significant trend, the error bars represent the $95 \%$ confidence interval. The insignificant trends are represented by hatched areas. The coloured labels correspond to the regions defined in Fig. 1.
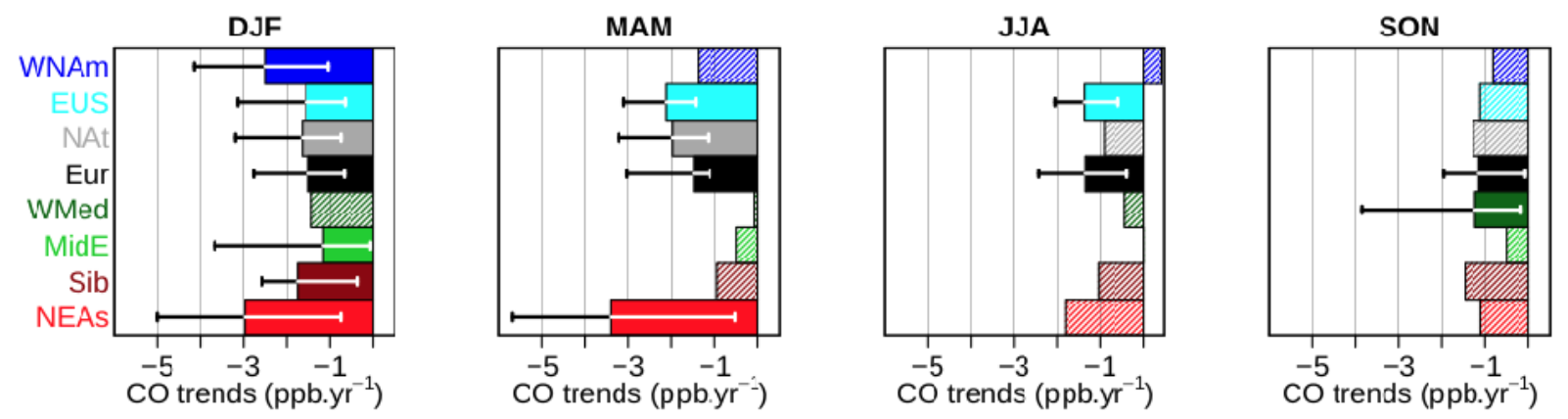

Figure 14. CO trends $\left(\mathrm{ppb} \mathrm{yr}^{-1}\right)$ in the UT in each season. For each significant trend, the error bars represent the $95 \%$ confidence interval. The insignificant trends are represented by hatched areas. The coloured labels correspond to the regions defined in Fig. 1.

$\left(-3.81[-6.75 ;-1.37] \mathrm{ppb} \mathrm{yr}^{-1}\right)$, about a factor of 2 higher than the trends observed in the eastern United States, the North Atlantic, Europe, and Siberia (about $-1.9 \mathrm{ppb} \mathrm{yr}^{-1}$ ), while no significant trend is found in both the Western Mediterranean basin and the Middle East. The particularity of these last two regions lies in a lower magnitude and the absence of significance in the P95 trends, compared to the five other regions (excluding northwest America, as mentioned previously). On one hand, as discussed in Sect. 3.2, they are expected to be less impacted by surface emissions, especially the Middle East because of a stronger subsidence. On the other hand, the $\mathrm{CO}$ decrease in the five other regions is influenced by less frequent and/or weaker high $\mathrm{CO}$ events, as suggested by the decrease in the P95. The strong interannual variability in the P95 in northeast Asia is probably due to boreal forest fires.

Figure 14 shows the seasonal trends of upper-tropospheric $\mathrm{CO}$. The mean values decrease significantly in most regions 
during winter, from $-1.15[-3.67 ;-0.06] \mathrm{ppb} \mathrm{yr}^{-1}$ in the Middle East to $-2.97[-5.00 ;-0.75] \mathrm{ppb} \mathrm{yr}^{-1}$ in northeast Asia. During springtime, the negative trends persist in all regions but Siberia and the Middle East. The summertime decrease is significant in the eastern United States and Europe only, and the trends during fall are barely significant in Europe and the Western Mediterranean basin. Europe appears as the only region where negative mean $\mathrm{CO}$ trends are observed during all four seasons (although with a very low significance level during fall). The general decrease is also observed for both the 5th and 95th percentiles during all seasons except fall. The highest negative trends are usually observed in northeast Asia. However, due to a strong interannual variability, they are not always significant. For instance, albeit insignificant, a very strong negative trend of the 95th percentile of $\mathrm{CO}$ is observed in this region during springtime $\left(-7.5 \mathrm{ppb} \mathrm{yr}^{-1}\right)$. This decrease with its associated large uncertainties is likely linked to the decadal decrease in Asian boreal forest fires mentioned in Jiang et al. (2017). The more homogeneous results obtained in winter compared to summer may be explained by a more efficient intercontinental transport of pollution. During winter, warm conveyor belt events are more frequent and uplift the air masses with extratropical origins (Madonna et al., 2014). Consequently, this transport pathway may enhance the response of uppertropospheric $\mathrm{CO}$ mixing ratios to the reduction in surface emissions by a homogenized wintertime negative trend.

Most of our results in the UT over Europe are in agreement with the study of Petetin et al. (2016) based on IAGOS data above Frankfurt and Munich airports, with similar CO negative trends. The main differences lie on an expected better significance for our trends because of the size of the Europe region allowing the use of a larger amount of data. It suggests the trends they derived in the UT above these airports are representative of the UT in Europe, and some of their insignificant trends are due to their limited amount of data, as they found insignificant trends in summer and autumn. They also found no significant trends for P5 during these seasons probably for the same reasons.

Over the whole troposphere, Worden et al. (2013) derived a global decrease in CO columns from MOPITT satellite observations over the period 2000-2011, with relative trends of $-1.42 \pm 0.40 \% \mathrm{yr}^{-1}$ in the eastern USA, $-1.44 \pm 0.44 \% \mathrm{yr}^{-1}$ in Europe, and $-1.60 \pm 0.96 \% \mathrm{yr}^{-1}$ in eastern China. At the global scale, the decrease in $\mathrm{CO}$ columns observed by MOPITT over the period 2000-2012 is about $-0.56 \% \mathrm{yr}^{-1}$ (Laken and Shahbaz, 2014). In the Northern Hemisphere, the decrease in $\mathrm{CO}$ mixing ratios at $500 \mathrm{hPa}$ observed by AIRS from 2003 until 2012 ranges between $-1.28 \mathrm{ppb} \mathrm{yr}^{-1}$ over land and $-1.01 \mathrm{ppb} \mathrm{yr}^{-1}$ over oceans (Worden et al., 2013). Using ground-based solar Fourier Transform InfraRed (FTIR) measurements at six European stations over the period 1998-2006, Angelbratt et al. (2011) observed similar negative trends of CO partial columns $(0-15 \mathrm{~km})$ in central/western Europe (around $-1.2 \pm 0.2 \% \mathrm{yr}^{-1}$ at Jungfraujoch and Zugspitze) and lower ones in northern Europe (about $-0.6 \pm 0.2 \% \mathrm{yr}^{-1}$ at Harestua, Norway, and Kiruna, Sweden). All these results remain consistent with the trends we found in the UT, although the mean estimate of our trend in northeast Asia is substantially higher $\left(-1.89[-2.87 ;-0.71] \% \mathrm{yr}^{-1}\right.$; see Table D7 in the Appendix). Gratz et al. (2015) analysed springtime surface observations at Mt Bachelor Observatory (Oregon; $2743 \mathrm{~m}$ a.s.l.) during 2004-2013 and showed a decrease of $-3.1 \pm 2.4 \mathrm{ppbyr}^{-1}$. They associated it with the decrease in $\mathrm{CO}$ anthropogenic emissions in Europe, North America, and China. The decrease is substantially higher than in our study, probably because it concerns the lower part of the free troposphere, which is more sensitive to the reduction in surface emissions.

The influence of the sampling frequency on the trends has been tested for each layer and each statistic by applying the sampling frequency to the monthly time series of the three most sampled regions (the eastern United States, the North Atlantic, Europe). The higher bias was obtained in the UT, for the mean values and the P5, with the sampling frequency of the Western Mediterranean basin and the Middle East. Applying the sampling frequency of these regions weakened the absolute $\mathrm{CO}$ trends by $0.2 \mathrm{ppb} \mathrm{yr}^{-1}$, which remains negligible.

\section{Summary and conclusions}

In the framework of the European research infrastructure IAGOS, in situ measurements of $\mathrm{O}_{3}$ and $\mathrm{CO}$ are performed in the UTLS since 1994 and 2002 respectively. Thanks to its high frequency of measurements over such long periods, IAGOS provides the most representative in situ data set in the UTLS. In the present study, we used the IAGOS data available until 2013 to establish a new semi-global climatology and to investigate the seasonal variability and trends in both $\mathrm{O}_{3}$ (19 years of data) and $\mathrm{CO}$ (12 years of data). Results are presented in three distinct layers, namely the upper troposphere (UT), tropopause layer (TPL), and lower stratosphere (LS). We also conducted a detailed interregional comparison of $\mathrm{O}_{3}, \mathrm{CO}$, and the $\mathrm{O}_{3} / \mathrm{CO}$ ratio in eight regions of interest at northern midlatitudes (northwest America, the eastern United States, the North Atlantic, Europe, the Western Mediterranean basin, the Middle East, Siberia, northeast Asia). These regions cover a wide range of longitudes excluding so far the Pacific Ocean. Note, however, that this Pacific region has been regularly visited by new IAGOS aircraft since mid-2012 (for a first analysis of these data, see Clark et al., 2015).

One of the objectives of the present study was to highlight the regional variability in the UTLS chemical composition in terms of horizontal distributions and trends. It is complementary to other analyses usually dealing with zonal means and/or focusing on the vertical gradients of chemical species. 
Air masses were attributed to UT, TPL, and LS based on the potential vorticity, following the methodology of Thouret et al. (2006) that first analysed the IAGOS data set in the UTLS. Added value to this first study lies in a 10-year longer monitoring period above the major part of the extratropical Northern Hemisphere, completed with 12 years of CO measurements. As a tracer for transport from the surface and as one of the major $\mathrm{O}_{3}$ precursors at the global scale, $\mathrm{CO}$ provides complementary information on the factors that control the $\mathrm{O}_{3}$ seasonal cycles and trends.

The analysis of the semi-global horizontal distributions of $\mathrm{O}_{3}$ and $\mathrm{CO}$ highlighted the following characteristics.

- At northern midlatitudes, the more efficient photochemical activity is associated with the common summertime $\mathrm{O}_{3}$ maximum in the UT, and the Brewer-Dobson circulation is associated with the common springtime $\mathrm{O}_{3}$ maximum in the LS. The general springtime CO maximum in the UT is seen as a consequence of the wintertime accumulation of emissions in the lower layers followed by an efficient vertical transport, before the summertime photochemical activity acts as a major sink for $\mathrm{CO}$. However, the $\mathrm{CO}$ maxima extend into summer over (and downwind of) regions where intense biomass burning occurs regularly, especially in Siberia. Another main feature of the northern extratropical UT relies on a zonal difference of $\mathrm{O}_{3}$ in summer (with up to $15 \mathrm{ppb}$ more over central Russia than in eastern North America) and an eastward gradient of $\mathrm{CO}$ from 60 to $140^{\circ} \mathrm{E}$, maximizing in spring and summer (approximately $5 \mathrm{ppb}$ by $10^{\circ}$ longitude).

- In the tropics, the CO mixing ratio maximizes in the regions of intense biomass burning. The $\mathrm{O}_{3}$ mixing ratios reach their maximum during fall over southern Africa, while the lowest values are found on both sides of the equatorial Pacific Ocean during most seasons.

$\mathrm{O}_{3}$ and $\mathrm{CO}$ seasonal variations were analysed in the eight extratropical regions of interest. The interregional comparison can be summarized as follows.

In the upper troposphere:

- In most regions, the $\mathrm{O}_{3}$ mixing ratios continuously increase from $40-50 \mathrm{ppbv}$ in winter to $70-90 \mathrm{ppbv}$ in summer. One regional specificity is found in northwest America and northeast Asia, where $\mathrm{O}_{3}$ mixing ratios start to decrease after May and June respectively (against July in other regions), likely due to the North American and Asian monsoons that bring $\mathrm{O}_{3}$-poor air masses from the subtropical Pacific Ocean in summer.

- The CO mixing ratios range from $80-90 \mathrm{ppbv}$ in fall to $110-140 \mathrm{ppbv}$ in spring in all regions except (i) northeast Asia, where this spring maximum extends to summer, and (ii) Siberia, where the CO mixing ratios show a levelling-off in spring-summer followed by a distinct peak in July.

- In all regions, the $\mathrm{O}_{3} / \mathrm{CO}$ ratio increases from $0.4-0.5$ in winter to $0.7-1.0$ in summer, the lowest values occurring in northwest America and the highest in the Western Mediterranean basin and the Middle East.

In the lower stratosphere:

- The $\mathrm{O}_{3}$ mixing ratios increase from $150-200 \mathrm{ppbv}$ in fall to $350-450 \mathrm{ppbv}$ in late spring-early summer in most regions, one noticeable exception relying on the Middle East where $\mathrm{O}_{3}$ quickly decreases after April (thus earlier and more strongly than in the other regions).

- Low CO mixing ratios ranging from 45 to $65 \mathrm{ppbv}$ are observed in the LS, with substantially lower and noisier seasonal variations in most regions compared to the UT, the main exceptions relying on the Middle East and northeast Asia where slightly higher $\mathrm{CO}$ mixing ratios are observed in summer.

- The $\mathrm{O}_{3} / \mathrm{CO}$ ratio increases from 3-5 in late fall-early winter to (i) 8 in spring in the Western Mediterranean basin and the Middle East and (ii) 10-12 in late springearly summer in the other regions. This lower $\mathrm{O}_{3} / \mathrm{CO}$ ratio observed in the two former regions can result from the subtropical air masses (low $\mathrm{O}_{3}$, high $\mathrm{CO}$ ) uplifted in the Asian monsoon and then transported northward by the western branch of the anticyclonic circulation.

Both in terms of mixing ratios and seasonal variations, the tropopause layer appears as a transition between these two previous layers.

The $\mathrm{O}_{3}$ and $\mathrm{CO}$ trends were also investigated in these different regions. The two-decadal trends in $\mathrm{O}_{3}$ are positive and statistically significant at the $95 \%$ level in most regions (excluding North Atlantic), with best estimates of trend ranging from +0.25 to $+0.45 \mathrm{ppb} \mathrm{yr}^{-1}$. This evolution appears to be linked to the increase in the lowest values and not necessarily to the highest values. Seasonal $\mathrm{O}_{3}$ mixing ratios show a significant increase during fall and winter in the three Atlantic sector regions (the eastern United States, the North Atlantic, and Europe) and a significant increase during spring or summer in Siberia and northeast Asia. Such an interregional difference in the seasonality of the $\mathrm{O}_{3}$ trends suggests that the increase in the Atlantic sector regions is linked to a long-term increase in the background mixing ratios, while emissions of precursors during favourable photochemical conditions still drive part of the increase over Asia. The $\mathrm{O}_{3}$ trends in the TPL are similar to the trends in the UT, albeit stronger and generally with a better significance. In contrast, all mean $\mathrm{O}_{3}$ trends remain insignificant in the LS. This is different from the results presented in Thouret et al. (2006), where the first 9 years of IAGOS data (1994-2003) showed significant positive trends in $\mathrm{O}_{3}$ in the LS, with the same magnitude as those 
in the UT. With an additional decade of observations, our present results suggest that the trends previously reported in the LS were influenced by the relatively low values over the period 1994-1997 (following the $\mathrm{O}_{3}$ reduction subsequent to the Pinatubo eruption in 1991) and the 1998-1999 positive anomaly (induced by the extreme El Niño event in 1997; Koumoutsaris et al., 2008).

In the UT, the mean $\mathrm{CO}$ mixing ratios significantly decrease in most regions (excluding the Middle East), with best estimates of trend ranging from -1.5 to $-2.2 \mathrm{ppb} \mathrm{yr}^{-1}$. Both 5th and 95th percentiles of the $\mathrm{CO}$ distribution also depict a negative trend, the decrease in the lowest values being more homogeneous compared to the highest values. At the seasonal scale, while summer and fall trends are either low or not significant, the $\mathrm{CO}$ mixing ratios are found to decrease significantly during winter in most regions. The strongest decrease is observed in northeast Asia during both winter and spring (approximately $-3 \% \mathrm{yr}^{-1}$ ). The decrease in $\mathrm{CO}$ in the northern extratropics is usually related to the reduction in anthropogenic emissions.

Identifying unambiguously the processes responsible for these trends would require a properly validated model and is thus beyond the scope of this paper, but one can still provide some insights. The decrease in $\mathrm{CO}$ is related to a reduction in the anthropogenic emissions. However, our study does not highlight a direct link between the long-term evolution of $\mathrm{O}_{3}$ and $\mathrm{CO}$ in the UT since both chemical species depict opposite trends. Although $\mathrm{CO}$ is only one precursor of $\mathrm{O}_{3}$ among many others, one may have expected that the reduction in its emissions would go hand in hand with the decrease in other $\mathrm{O}_{3}$ precursors. However, rapid changes in the technology used in the various combustion processes may change the speciation of the emissions. In addition, many other chemical species not co-emitted with $\mathrm{CO}$ (e.g. biogenic compounds) play a role in the $\mathrm{O}_{3}$ budget.

The lowest trends in both $\mathrm{O}_{3}$ and $\mathrm{CO}$ in the Middle East region, where the UT is less influenced by the middle and lower troposphere, may reflect a significant global tropospheric contribution driving the higher trends in $\mathrm{O}_{3}$ and $\mathrm{CO}$ over other regions. This would be in line with recent findings by Zhang et al. (2016), attributing the major part of the increase in the Northern Hemisphere tropospheric $\mathrm{O}_{3}$ burden to the growing (sub)tropical emissions. However, the increase in $\mathrm{O}_{3}$ mixing ratios in the UT occurs in almost every extratropical region, and the interregional differences are not statistically significant enough to exclude other leading processes.

We compared our results to other studies analysing trends at lower levels in the free troposphere. The $\mathrm{O}_{3}$ increase is usually weaker at free-tropospheric GAW stations than in the middle and upper troposphere. For instance, based on aircraft, sondes, and surface measurements in Japan from 1991 to 2015, Tanimoto et al. (2018) recently highlighted a dependence of the $\mathrm{O}_{3}$ trends on altitude, with an $\mathrm{O}_{3}$ levellingoff in the 2000s in the lower part of the free troposphere but a persistent increase in the middle and upper troposphere. This suggests that the $\mathrm{O}_{3}$ trends in the UT may be linked to an increase in in situ local emissions of precursors in the UT (lightning, aircraft) and/or stratosphere-to-troposphere $\mathrm{O}_{3}$ flux as reported in other studies (e.g. Neu et al., 2014a). This would also be consistent with the increasing vertical cross-tropopause mass flux in the extratropics during 19962011 modelled with ERA-Interim and JRA-55 reanalyses (Boothe and Homeyer, 2017), linked to the acceleration of the Brewer-Dobson circulation, in agreement with observations and chemistry-climate models (Butchart, 2014, and references therein; more recently, Garfinkel et al., 2017). An increase in the stratospheric influence on the $\mathrm{O}_{3}$ mixing ratios in the UT can result from (i) an increasing number of stratospheric intrusions and/or (ii) the stratospheric $\mathrm{O}_{3}$ recovery (both leading to an enhancement of the stratosphere-totroposphere $\mathrm{O}_{3}$ fluxes). Our study does not support this second option since all mean $\mathrm{O}_{3}$ trends in the LS were found to be statistically insignificant over the studied period, although the insignificance of our trends may be due to the interannual variability. Finally, attributing the trends of $\mathrm{O}_{3}$ in the UT to one leading process remains difficult and requires further investigations with global models.

The IAGOS data set has highlighted significant interregional and interannual variabilities, which can provide helpful information for shorter and/or localized measurement campaigns. Its good vertical accuracy in the UTLS makes it a useful data set for evaluating the ability of current chemistrytransport and chemistry-climate models to reproduce the characteristics of the chemical composition in this layer, including climatologies and trends.

Data availability. All ozone and carbon monoxide data used in this study were obtained from the existing IAGOS database, freely available on the IAGOS website (http://www.iagos.org) and via the AERIS website (http://www.aeris-data.fr). 


\section{Appendix A: Horizontal distributions: $\mathrm{O}_{3} / \mathrm{CO}$ ratio}
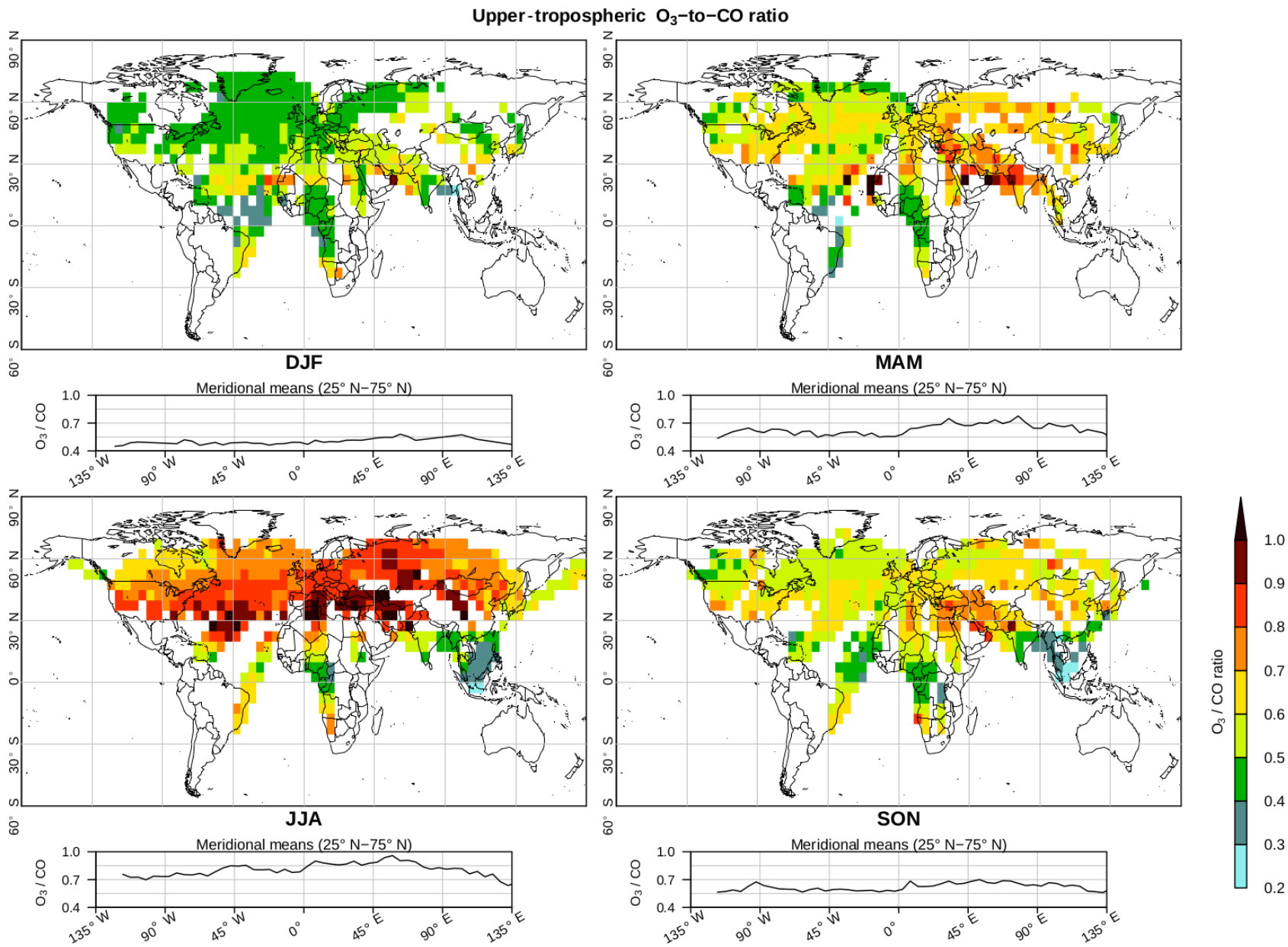

Figure A1. Horizontal distributions of the $\mathrm{O}_{3}$-to-CO ratio in the UT averaged from December 2001 to November 2013 , in every season. Each 2-D distribution is projected onto the zonal axis below, with a meridional average of the northern extratropical zonal band (from 25 to $\left.75^{\circ} \mathrm{N}\right)$. The 2-D (1-D) distributions have a $5^{\circ} \times 5^{\circ}\left(5^{\circ}\right)$ resolution. The $x$ axes are the same in the maps and in the projections below. 
Appendix B: Time series: monthly and yearly means

Upper-tropospheric $\mathrm{O}_{3}$
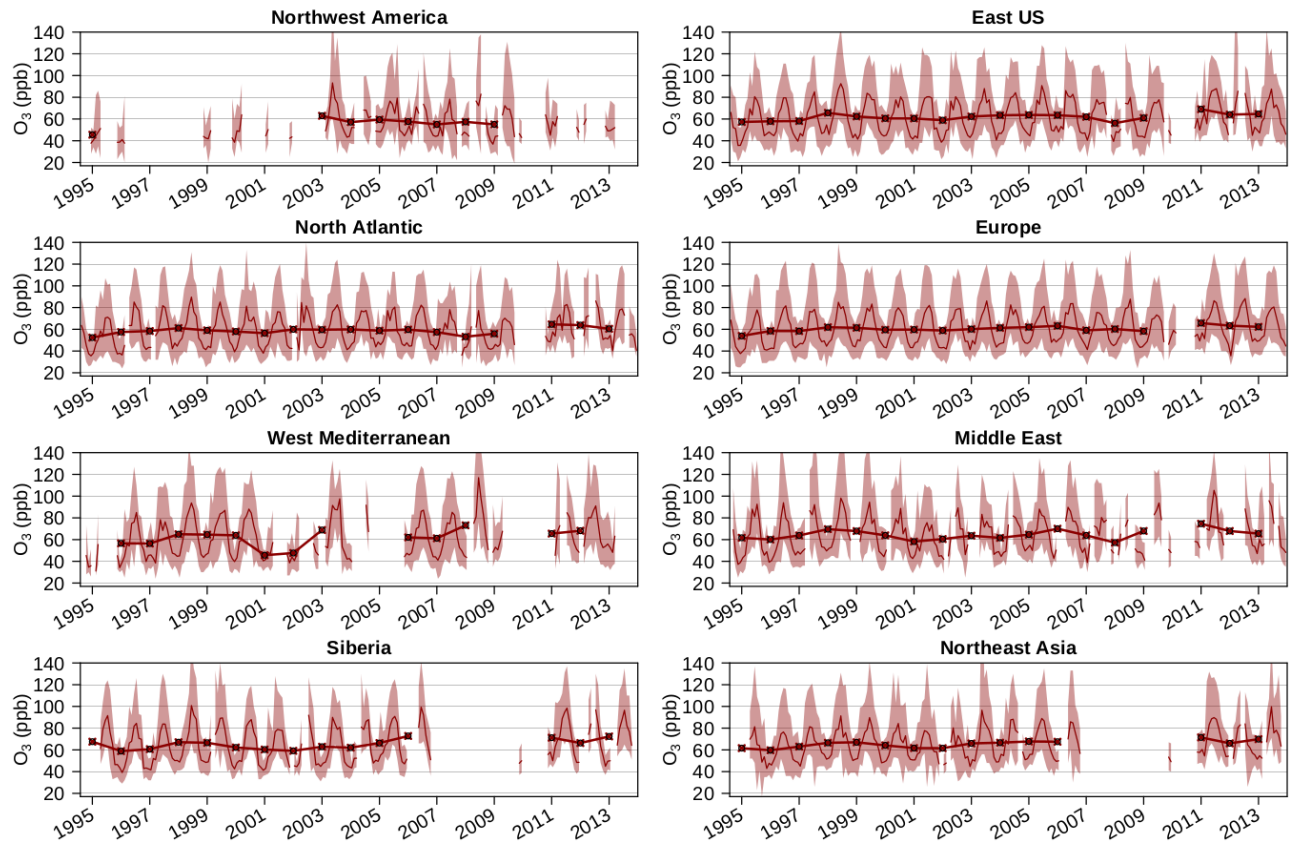

Figure B1. $\mathrm{O}_{3}$ monthly mean values in the UT (thin curve). The interval from 5th and 95th percentiles is filled in red. The yearly mean values are represented by the bold curve and the black points.

Tropopause layer $\mathrm{O}_{3}$
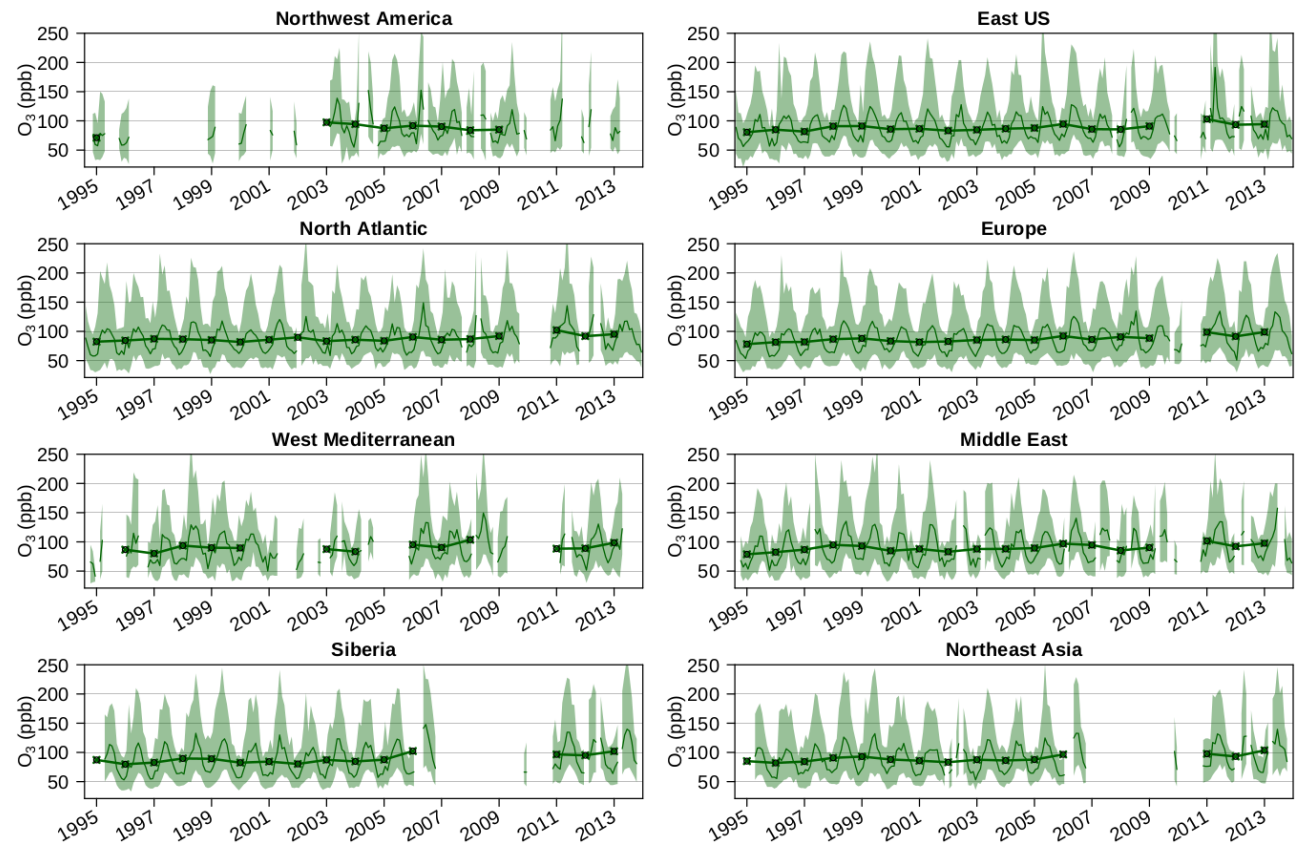

Figure B2. $\mathrm{O}_{3}$ monthly mean values in the TPL (thin curve). The interval from 5 th and 95th percentiles is filled in green. The yearly mean values are represented by the bold curve and the black points. 


\section{Lower-stratospheric $\mathrm{O}_{3}$}
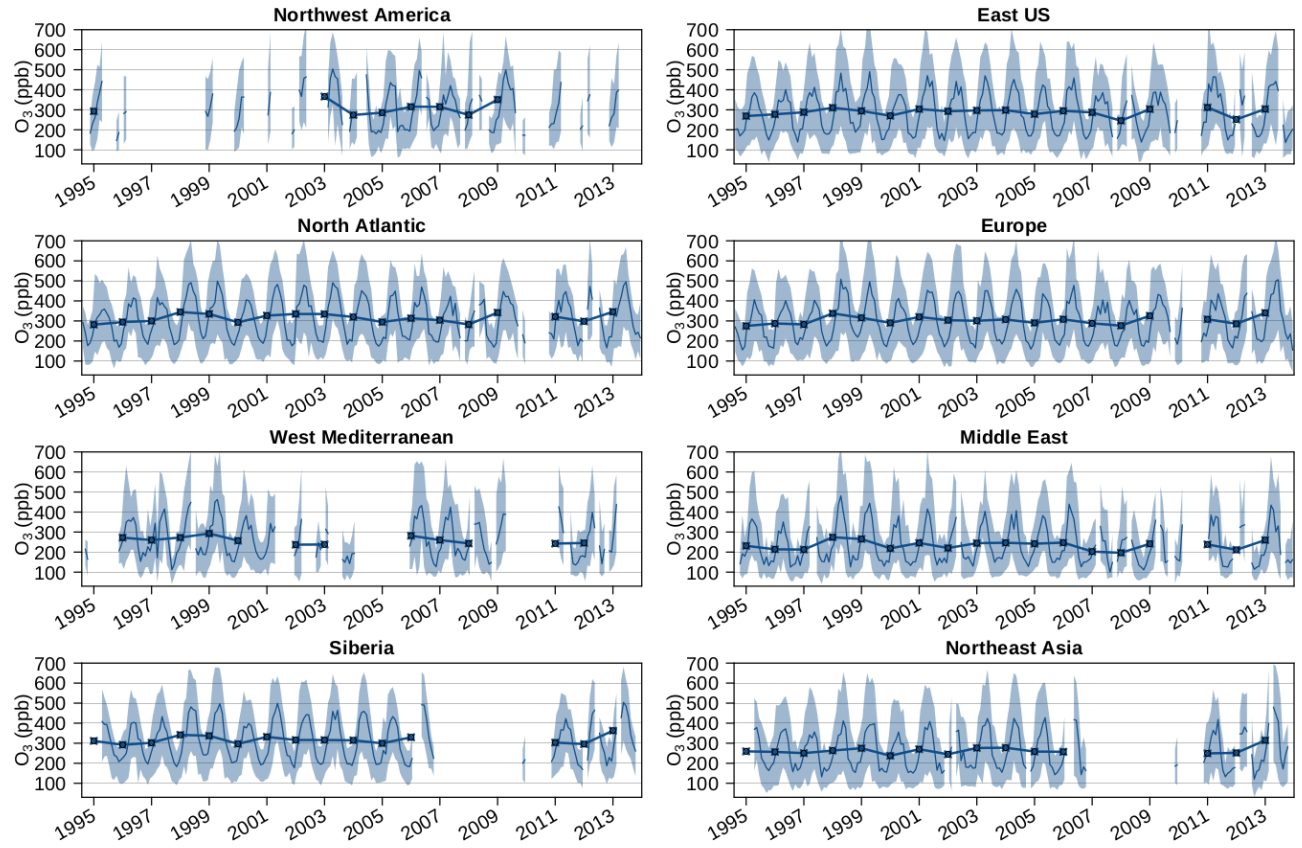

Figure B3. $\mathrm{O}_{3}$ monthly mean values in the LS (thin curve). The interval from 5 th and 95th percentiles is filled in blue. The yearly mean values are represented by the bold curve and the black points.

\section{Upper-tropospheric CO}
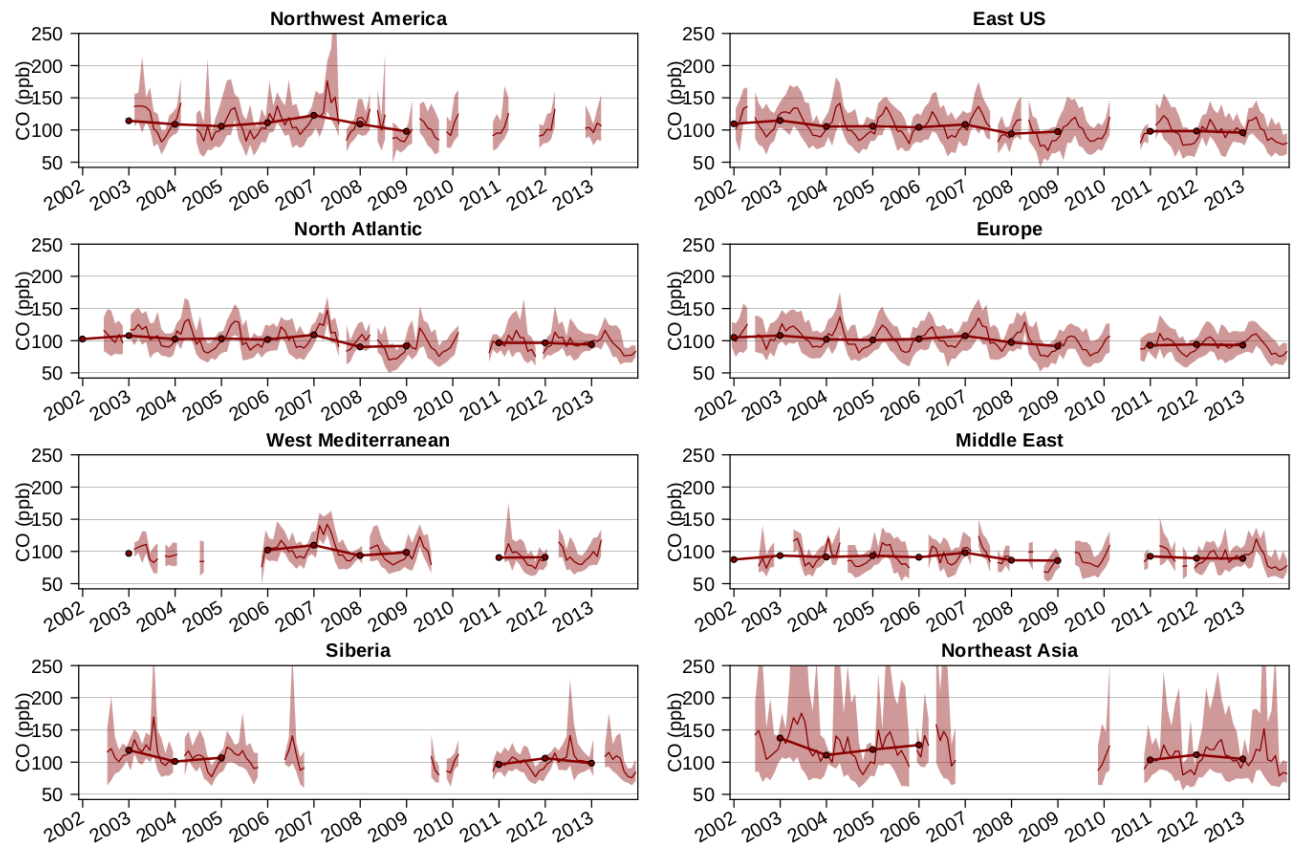

Figure B4. CO monthly mean values in the UT (thin curve). The interval from 5th and 95th percentiles is filled in red. The yearly mean values are represented by the bold curve and the black points. 


\section{Tropopause layer CO}
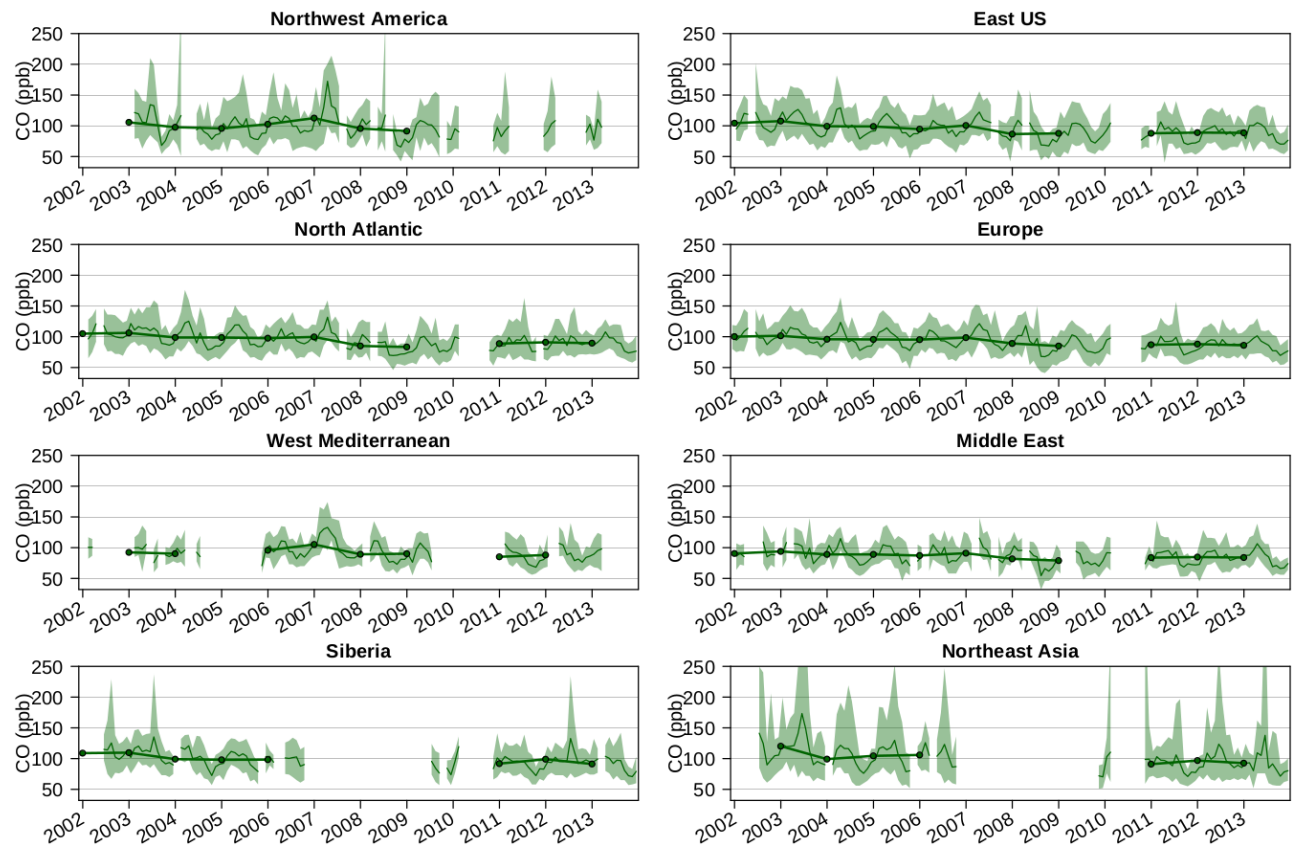

Figure B5. CO monthly mean values in the TPL (thin curve). The interval from 5th and 95th percentiles is filled in green. The yearly mean values are represented by the bold curve and the black points.

\section{Lower - stratospheric CO}
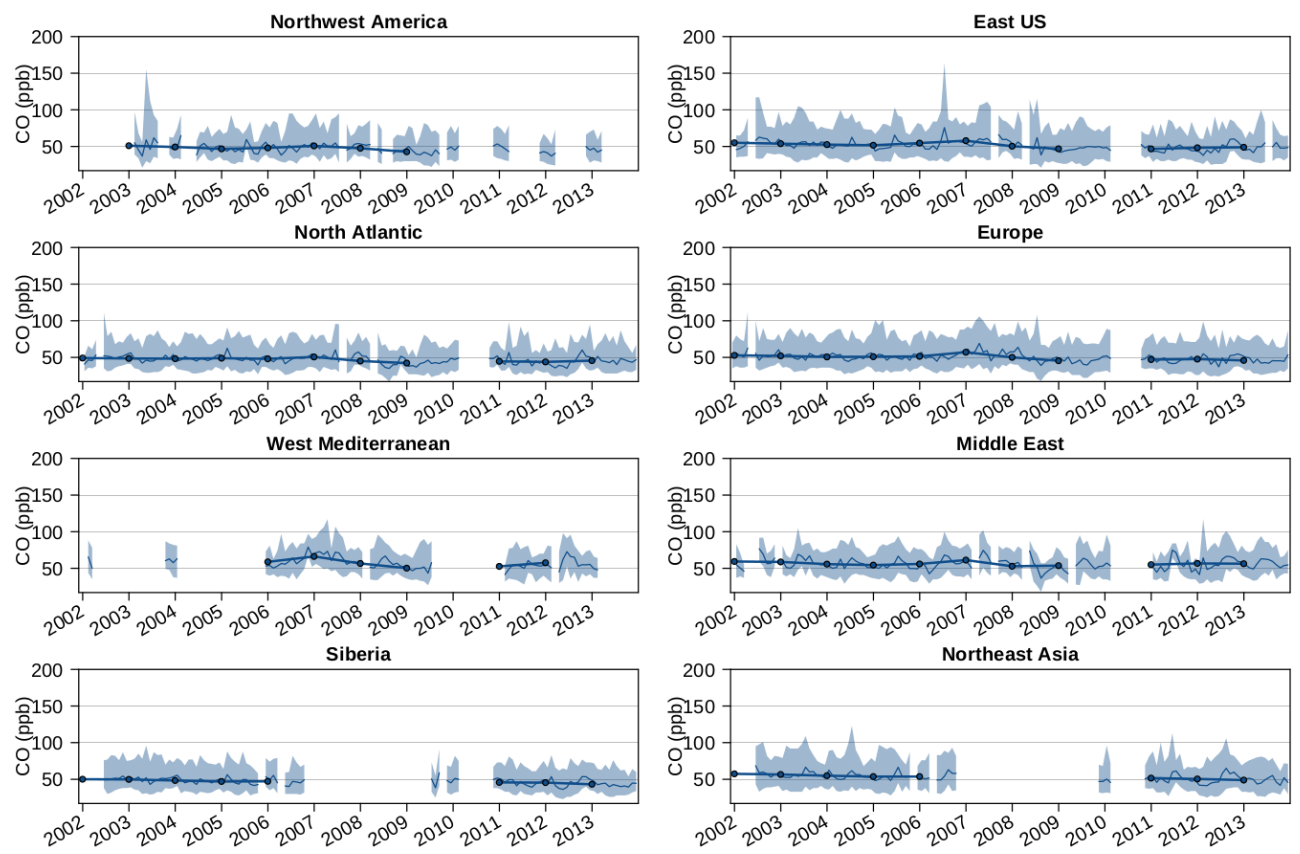

Figure B6. CO monthly mean values in the LS (thin curve). The interval from 5th and 95th percentiles is filled in blue. The yearly mean values are represented by the bold curve and the black points. 
Appendix C: Monthly anomalies

\section{Upper-tropospheric $\mathrm{O}_{3}$}
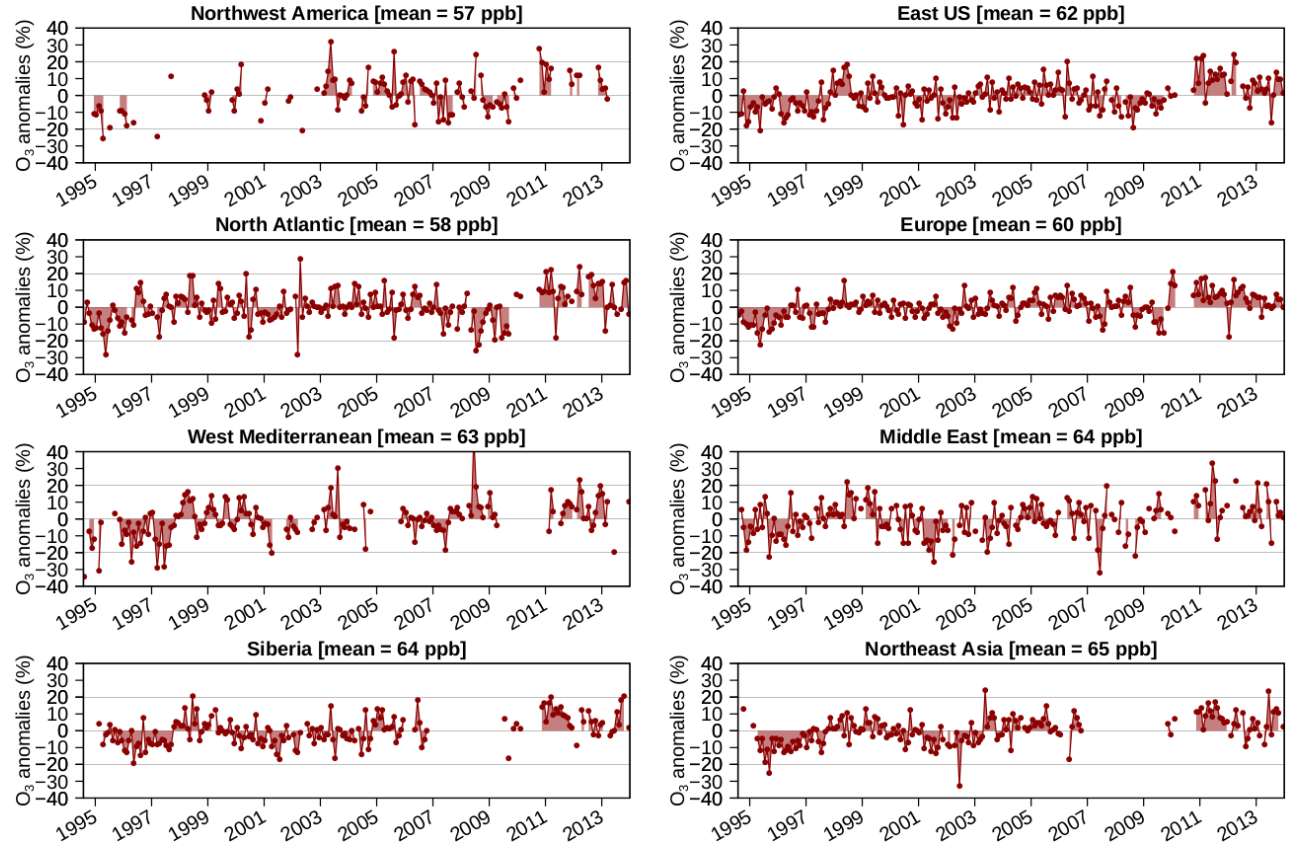

Figure C1. Relative monthly anomalies of $\mathrm{O}_{3}$ volume mixing ratio in the upper troposphere. The units \% refer to the corresponding climatological means indicated above each graph.

\section{Lower-stratospheric $\mathrm{O}_{3}$}
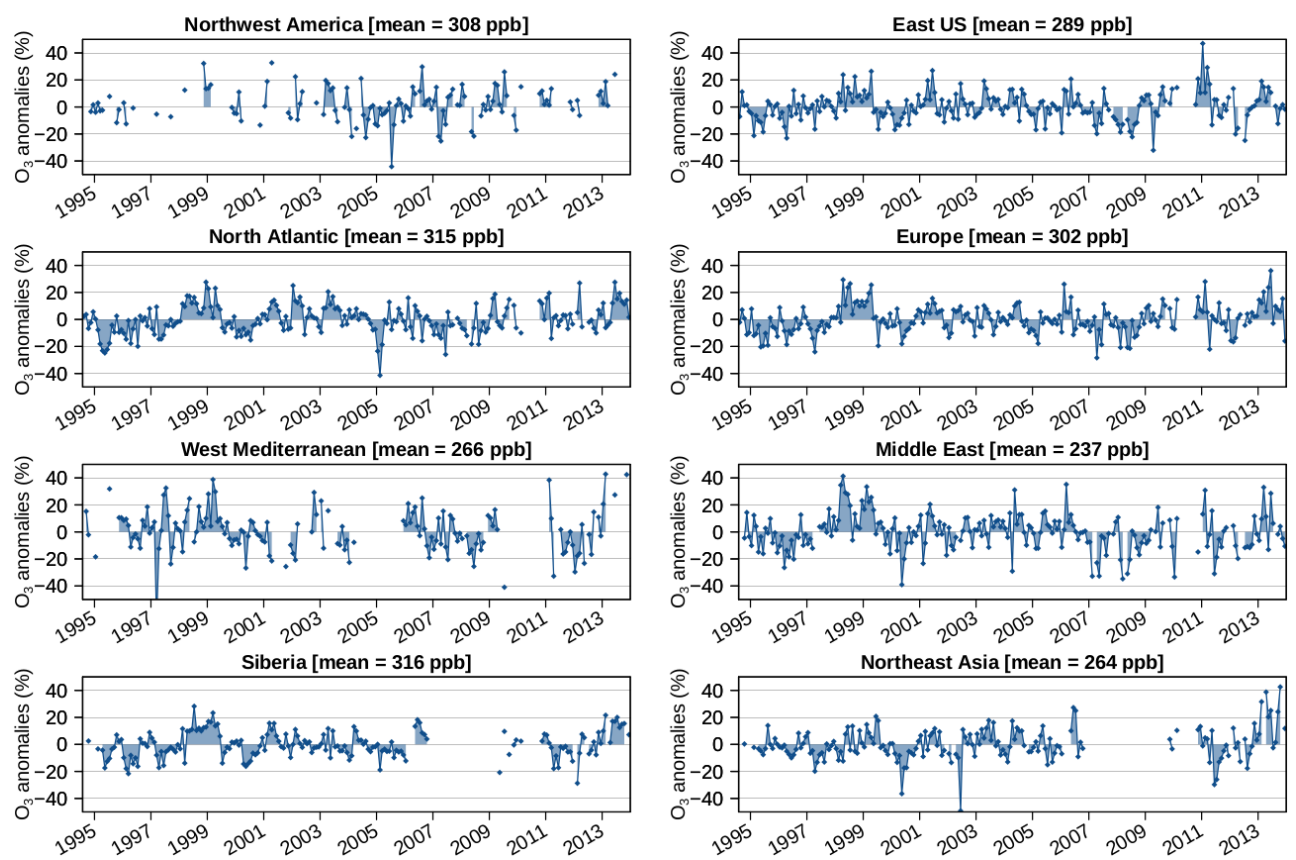

Figure C2. Relative monthly anomalies of $\mathrm{O}_{3}$ volume mixing ratio in the lower stratosphere. The units \% refer to the corresponding climatological means indicated above each graph. 


\section{Upper-tropospheric CO}
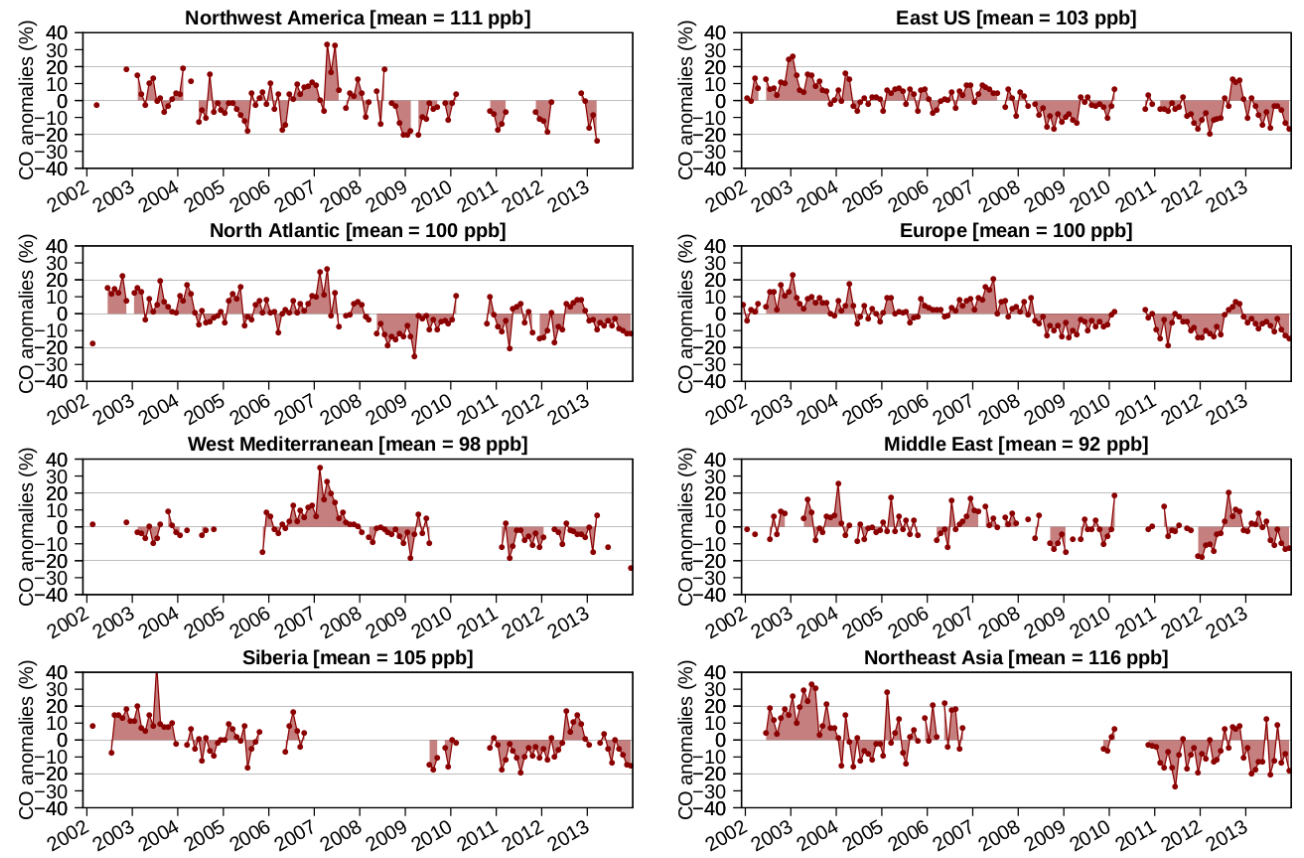

Figure C3. Relative monthly anomalies of $\mathrm{CO}$ volume mixing ratio in the upper troposphere. The units \% refer to the corresponding climatological means indicated above each graph.

\section{Lower-stratospheric CO}
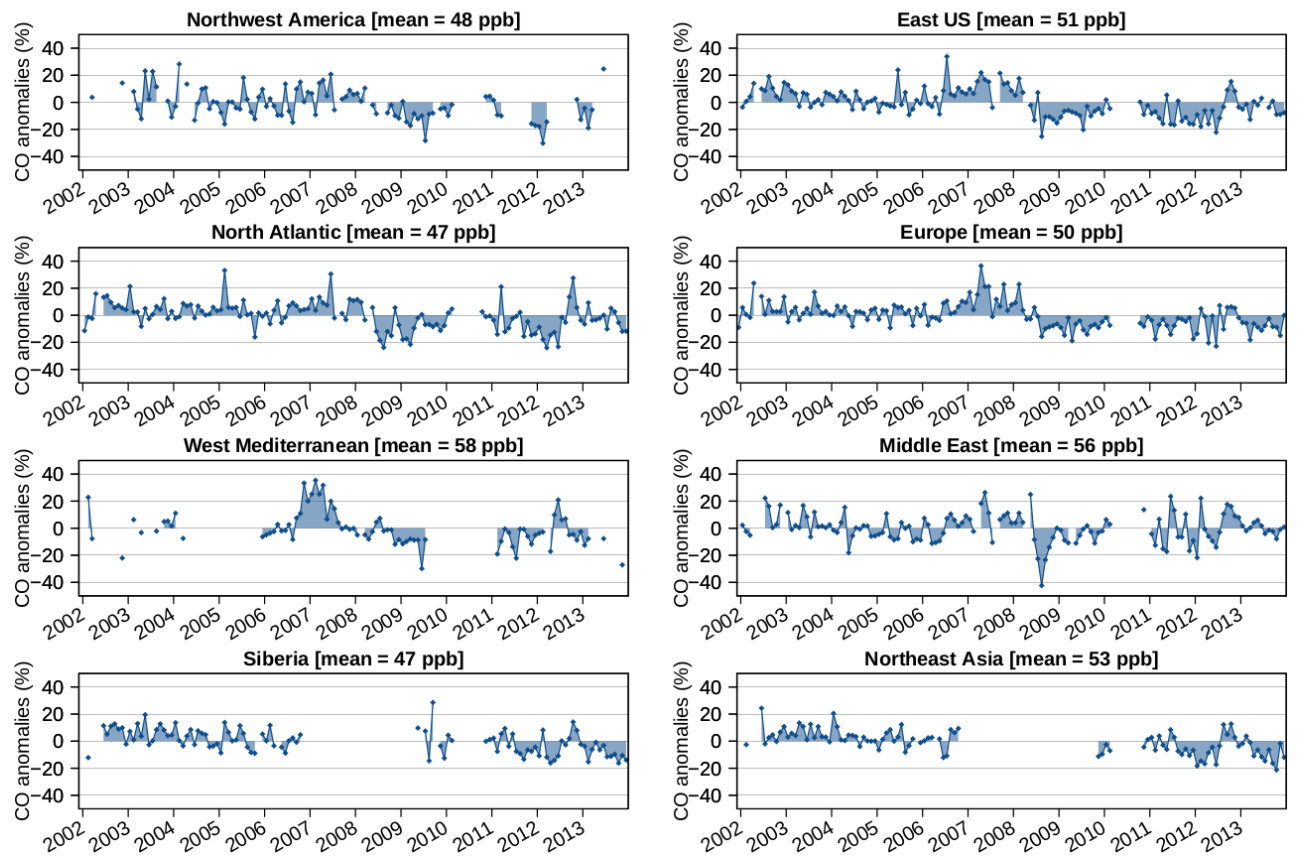

Figure C4. Relative monthly anomalies of $\mathrm{CO}$ volume mixing ratio in the lower stratosphere. The units $\%$ refer to the corresponding climatological means indicated above each graph. 
Appendix D: Tables of trends

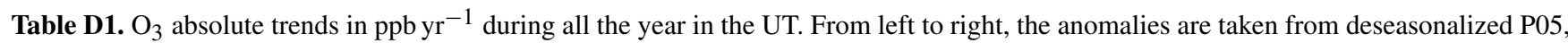
monthly means, and P95. The insignificant trends with respect to the $95 \%$ confidence level are indicated as NS.

\begin{tabular}{|c|c|c|c|c|c|c|c|c|c|c|}
\hline \multirow{2}{*}{$\begin{array}{l}\text { Season } \\
\left(\mathrm{ppb} \mathrm{yr}^{-1}\right)\end{array}$} & \multirow[t]{2}{*}{ Region } & \multicolumn{3}{|c|}{ P05 } & \multicolumn{3}{|c|}{ Mean } & \multicolumn{3}{|c|}{ P95 } \\
\hline & & Slope & Conf. int. (95\%) & $p$ value & Slope & Conf. int. (95\%) & $p$ value & Slope & Conf. int. (95\%) & $p$ value \\
\hline \multirow[t]{7}{*}{ ANN } & EUS & 0.44 & {$[0.19 ; 0.64]$} & 0.003 & 0.34 & {$[0.09 ; 0.50]$} & 0.013 & \multirow{7}{*}{$\begin{array}{l}0.29 \\
0.64\end{array}$} & NS & \multirow{7}{*}{$\begin{array}{r}0.022 \\
0.04\end{array}$} \\
\hline & NAt & 0.43 & {$[0.18 ; 0.62]$} & 0.003 & & NS & & & NS & \\
\hline & Eur & 0.35 & {$[0.18 ; 0.50]$} & $<10^{-3}$ & 0.31 & {$[0.14 ; 0.45]$} & 0.003 & & {$[0.06 ; 0.47]$} & \\
\hline & WMed & 0.34 & {$[0.08 ; 0.52]$} & 0.003 & 0.42 & {$[0.14 ; 0.64]$} & 0.003 & & {$[0.06 ; 1.16]$} & \\
\hline & MidE & 0.30 & {$[0.12 ; 0.48]$} & 0.007 & 0.25 & {$[0.01 ; 0.45]$} & 0.037 & & NS & \\
\hline & Sib & 0.50 & {$[0.31 ; 0.67]$} & $<10^{-3}$ & 0.37 & {$[0.12 ; 0.58]$} & 0.007 & & NS & \\
\hline & NEAs & 0.57 & {$[0.35 ; 0.80]$} & $<10^{-3}$ & 0.45 & {$[0.23 ; 0.68]$} & $<10^{-3}$ & & NS & \\
\hline
\end{tabular}

Table D2. $\mathrm{O}_{3}$ absolute trends in $\mathrm{ppb} \mathrm{yr}^{-1}$ during each season in the UT. From left to right, the anomalies are taken from deseasonalized P05, monthly means, and P95. The insignificant trends with respect to the $95 \%$ confidence level are indicated as NS.

\begin{tabular}{|c|c|c|c|c|c|c|c|c|c|c|}
\hline \multirow{2}{*}{$\begin{array}{l}\text { Season } \\
\left(\mathrm{ppb} \mathrm{yr}^{-1}\right)\end{array}$} & \multirow[t]{2}{*}{ Region } & \multicolumn{3}{|c|}{ P05 } & \multicolumn{3}{|c|}{ Mean } & \multicolumn{3}{|c|}{ P95 } \\
\hline & & Slope & Conf. int. (95\%) & $p$ value & Slope & Conf. int. (95\%) & $p$ value & Slope & Conf. int. (95\%) & $p$ value \\
\hline \multirow[t]{7}{*}{ DJF } & EUS & 0.50 & {$[0.16 ; 0.93]$} & 0.007 & 0.38 & {$[0.01 ; 0.61]$} & 0.04 & & NS & \\
\hline & NAt & 0.54 & {$[0.34 ; 0.84]$} & $<10^{-3}$ & 0.43 & {$[0.13 ; 0.65]$} & 0.003 & & NS & \\
\hline & Eur & 0.41 & {$[0.13 ; 0.72]$} & $<10^{-3}$ & 0.37 & {$[0.11 ; 0.62]$} & 0.003 & 0.43 & {$[0.10 ; 0.88]$} & 0.008 \\
\hline & WMed & & NS & & & NS & & & NS & \\
\hline & MidE & & NS & & & NS & & & NS & \\
\hline & Sib & 0.50 & {$[0.11 ; 0.91]$} & 0.02 & & NS & & & NS & \\
\hline & NEAs & 0.34 & {$[0.12 ; 0.76]$} & 0.003 & & NS & & & NS & \\
\hline \multirow[t]{7}{*}{ MAM } & EUS & & NS & & & NS & & & NS & \\
\hline & NAt & 0.63 & {$[0.09 ; 1.03]$} & 0.028 & & NS & & & NS & \\
\hline & Eur & & NS & & & NS & & & NS & \\
\hline & WMed & 0.53 & {$[0.10 ; 1.11]$} & 0.037 & & NS & & & NS & \\
\hline & MidE & 0.48 & {$[0.15 ; 1.00]$} & 0.017 & & NS & & & NS & \\
\hline & Sib & 0.56 & {$[0.24 ; 1.00]$} & 0.018 & 0.50 & {$[0.11 ; 0.88]$} & 0.023 & & NS & \\
\hline & NEAs & 0.56 & {$[0.17 ; 0.82]$} & 0.007 & & NS & & & NS & \\
\hline \multirow[t]{7}{*}{ JJA } & EUS & & NS & & & NS & & & NS & \\
\hline & NAt & & NS & & & NS & & & NS & \\
\hline & Eur & & NS & & & NS & & & NS & \\
\hline & WMed & & NS & & & NS & & & NS & \\
\hline & MidE & & NS & & & NS & & & NS & \\
\hline & Sib & 0.60 & {$[0.42 ; 0.91]$} & $<10^{-3}$ & & NS & & & NS & \\
\hline & NEAs & 1.07 & {$[0.58 ; 1.42]$} & 0.003 & 0.84 & {$[0.23 ; 1.36]$} & 0.01 & & NS & \\
\hline \multirow[t]{7}{*}{ SON } & EUS & 0.44 & {$[0.05 ; 0.76]$} & 0.012 & 0.47 & {$[0.11 ; 0.64]$} & 0.013 & & NS & \\
\hline & NAt & & NS & & & NS & & & NS & \\
\hline & Eur & 0.40 & {$[0.00 ; 0.64]$} & 0.045 & 0.35 & {$[0.04 ; 0.64]$} & 0.033 & & NS & \\
\hline & WMed & 0.38 & {$[0.16 ; 0.54]$} & 0.003 & 0.47 & {$[0.11 ; 0.67]$} & 0.02 & & NS & \\
\hline & MidE & 0.26 & {$[0.05 ; 0.52]$} & 0.023 & 0.35 & {$[0.09 ; 0.69]$} & 0.01 & & NS & \\
\hline & Sib & & NS & & & NS & & & NS & \\
\hline & NEAs & & NS & & 0.38 & {$[0.04 ; 0.67]$} & 0.043 & & NS & \\
\hline
\end{tabular}


Table D3. $\mathrm{O}_{3}$ relative trends in $\% \mathrm{yr}^{-1}$ during all the year in the UT. From left to right, the anomalies are taken from deseasonalized P05, monthly means, and P95. The insignificant trends with respect to the $95 \%$ confidence level are indicated as NS.

\begin{tabular}{|c|c|c|c|c|c|c|c|c|c|c|}
\hline \multirow{2}{*}{$\begin{array}{l}\text { Season } \\
\left(\% \mathrm{yr}^{-1}\right)\end{array}$} & \multirow[t]{2}{*}{ Region } & \multicolumn{3}{|c|}{ P05 } & \multicolumn{3}{|c|}{ Mean } & \multicolumn{3}{|c|}{ P95 } \\
\hline & & Slope & Conf. int. (95\%) & $p$ value & Slope & Conf. int. (95\%) & $p$ value & Slope & Conf. int. (95\%) & $p$ value \\
\hline \multirow[t]{7}{*}{ ANN } & EUS & 1.10 & {$[0.48 ; 1.61]$} & 0.003 & 0.55 & {$[0.14 ; 0.80]$} & 0.013 & \multirow{7}{*}{$\begin{array}{l}0.33 \\
0.70\end{array}$} & NS & \multirow{7}{*}{$\begin{array}{r}0.022 \\
0.04\end{array}$} \\
\hline & NAt & 1.10 & {$[0.45 ; 1.59]$} & 0.003 & & NS & & & NS & \\
\hline & Eur & 0.88 & {$[0.46 ; 1.24]$} & $<10^{-3}$ & 0.51 & {$[0.23 ; 0.75]$} & 0.003 & & {$[0.07 ; 0.53]$} & \\
\hline & WMed & 0.82 & {$[0.19 ; 1.28]$} & 0.003 & 0.67 & {$[0.23 ; 1.02]$} & 0.003 & & {$[0.07 ; 1.26]$} & \\
\hline & MidE & 0.68 & {$[0.27 ; 1.08]$} & 0.007 & 0.39 & {$[0.01 ; 0.70]$} & 0.037 & & NS & \\
\hline & $\mathrm{Sib}$ & 1.06 & {$[0.66 ; 1.42]$} & $<10^{-3}$ & 0.58 & {$[0.19 ; 0.91]$} & 0.007 & & NS & \\
\hline & NEAs & 1.26 & {$[0.77 ; 1.78]$} & $<10^{-3}$ & 0.69 & {$[0.35 ; 1.04]$} & $<10^{-3}$ & & NS & \\
\hline
\end{tabular}

Table D4. $\mathrm{O}_{3}$ relative trends in $\% \mathrm{yr}^{-1}$ during each season in the UT. From left to right, the anomalies are taken from deseasonalized P05, monthly means, and P95. The insignificant trends with respect to the $95 \%$ confidence level are indicated as NS.

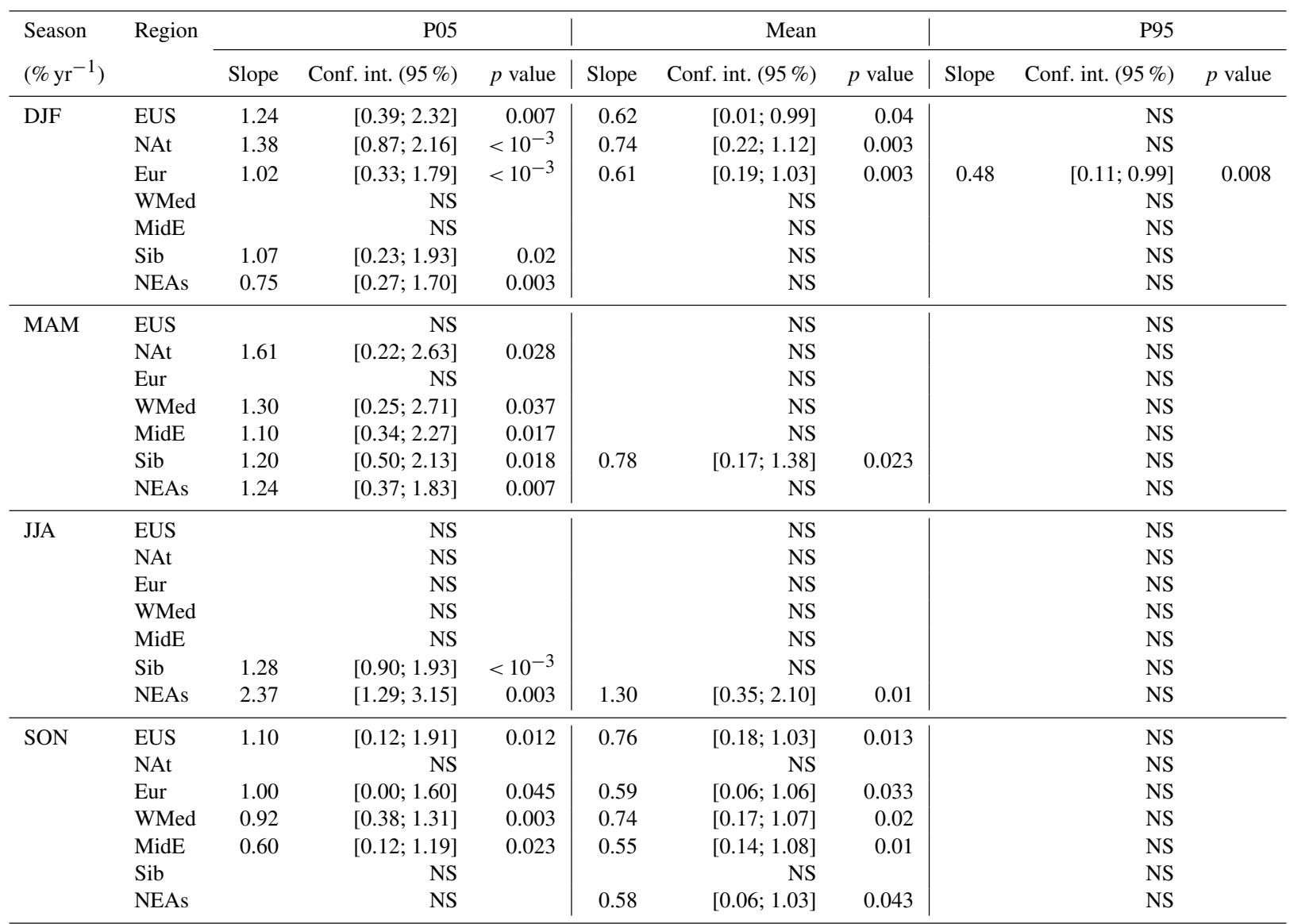




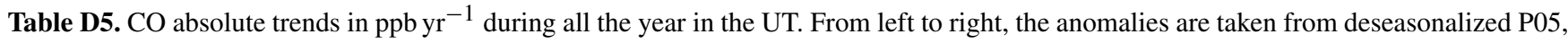
monthly means, and P95. The insignificant trends with respect to the $95 \%$ confidence level are indicated as NS.

\begin{tabular}{|c|c|c|c|c|c|c|c|c|c|c|}
\hline \multirow{2}{*}{ 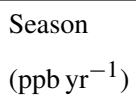 } & \multirow[t]{2}{*}{ Region } & \multicolumn{3}{|c|}{ P05 } & \multicolumn{3}{|c|}{ Mean } & \multicolumn{3}{|c|}{ P95 } \\
\hline & & Slope & Conf. int. (95\%) & $p$ value & Slope & Conf. int. (95\%) & $p$ value & Slope & Conf. int. (95\%) & $p$ value \\
\hline \multirow[t]{7}{*}{ ANN } & EUS & -1.37 & {$[-1.92 ;-0.75]$} & $<10^{-3}$ & -1.53 & {$[-2.08 ;-0.98]$} & $<10^{-3}$ & -2.12 & {$[-2.80 ;-1.10]$} & $<10^{-3}$ \\
\hline & NAt & -0.98 & {$[-1.77 ;-0.45]$} & 0.003 & -1.38 & {$[-1.98 ;-0.69]$} & $<10^{-3}$ & -1.79 & {$[-2.61 ;-0.79]$} & $<10^{-3}$ \\
\hline & Eur & -1.08 & {$[-1.63 ;-0.63]$} & $<10^{-3}$ & -1.41 & {$[-1.96 ;-0.90]$} & $<10^{-3}$ & -1.89 & {$[-2.47 ;-1.28]$} & $<10^{-3}$ \\
\hline & WMed & -0.93 & {$[-2.02 ;-0.31]$} & 0.003 & -0.80 & {$[-2.06 ;-0.14]$} & 0.013 & & NS & \\
\hline & MidE & -0.59 & {$[-1.17 ;-0.07]$} & 0.027 & & NS & & & NS & \\
\hline & $\mathrm{Sib}$ & -0.84 & {$[-1.48 ;-0.26]$} & 0.007 & -1.38 & {$[-2.15 ;-0.32]$} & 0.01 & -1.56 & {$[-2.98 ;-0.19]$} & 0.02 \\
\hline & NEAs & -1.22 & {$[-2.02 ;-0.56]$} & $<10^{-3}$ & -2.19 & {$[-3.33 ;-0.82]$} & 0.003 & -3.81 & {$[-6.75 ;-1.37]$} & 0.003 \\
\hline
\end{tabular}

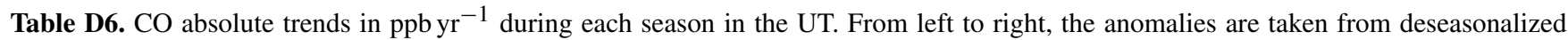
P05, monthly means, and P95. The insignificant trends with respect to the $95 \%$ confidence level are indicated as NS. Note that the trends in northwest America are available only in DJF.

\begin{tabular}{|c|c|c|c|c|c|c|c|c|c|c|}
\hline \multirow{2}{*}{$\begin{array}{l}\text { Season } \\
\left(\mathrm{ppb} \mathrm{yr}^{-1}\right)\end{array}$} & \multirow[t]{2}{*}{ Region } & \multicolumn{3}{|c|}{ P05 } & \multicolumn{3}{|c|}{ Mean } & \multicolumn{3}{|c|}{ P95 } \\
\hline & & Slope & Conf. int. (95\%) & $p$ value & Slope & Conf. int. (95\%) & $p$ value & Slope & Conf. int. (95\%) & $p$ value \\
\hline \multirow[t]{8}{*}{ DJF } & WNAm & & NS & & -2.48 & {$[-4.14 ;-1.04]$} & 0.02 & -3.30 & {$[-6.25 ;-1.12]$} & 0.003 \\
\hline & EUS & & NS & & -1.56 & {$[-3.13 ;-0.65]$} & $<10^{-3}$ & -2.42 & {$[-3.42 ;-1.42]$} & $<10^{-3}$ \\
\hline & NAt & & NS & & -1.65 & {$[-3.19 ;-0.75]$} & 0.007 & -2.68 & {$[-4.21 ;-1.46]$} & 0.005 \\
\hline & Eur & -1.24 & {$[-2.32 ;-0.37]$} & 0.01 & -1.49 & {$[-2.77 ;-0.67]$} & 0.007 & -2.15 & {$[-3.54 ;-1.19]$} & 0.007 \\
\hline & WMed & & NS & & & NS & & & NS & \\
\hline & MidE & & NS & & -1.15 & {$[-3.67 ;-0.06]$} & 0.05 & & NS & \\
\hline & Sib & -0.99 & {$[-2.24 ;-0.15]$} & 0.035 & -1.75 & {$[-2.56 ;-0.35]$} & 0.023 & -1.43 & {$[-3.24 ;-0.39]$} & 0.025 \\
\hline & NEAs & -2.51 & {$[-3.32 ;-1.55]$} & $<10^{-3}$ & -2.97 & {$[-5.00 ;-0.75]$} & 0.01 & & NS & \\
\hline \multirow[t]{7}{*}{ MAM } & EUS & -1.92 & {$[-3.03 ;-1.00]$} & $<10^{-3}$ & -2.11 & {$[-3.10 ;-1.45]$} & $<10^{-3}$ & -2.66 & {$[-3.86 ;-0.99]$} & 0.017 \\
\hline & NAt & -1.88 & {$[-3.81 ;-0.79]$} & 0.013 & -1.97 & {$[-3.24 ;-1.16]$} & 0.003 & & NS & \\
\hline & Eur & -1.19 & {$[-2.42 ;-0.26]$} & 0.017 & -1.49 & {$[-3.03 ;-1.12]$} & 0.003 & -2.03 & {$[-3.69 ;-1.51]$} & 0.003 \\
\hline & WMed & & NS & & & NS & & & NS & \\
\hline & MidE & & NS & & & NS & & & NS & \\
\hline & Sib & & NS & & & NS & & & NS & \\
\hline & NEAs & -1.54 & {$[-2.55 ;-0.02]$} & 0.05 & -3.42 & {$[-5.70 ;-0.53]$} & 0.03 & & NS & \\
\hline \multirow[t]{7}{*}{ JJA } & EUS & -1.39 & {$[-2.09 ;-0.85]$} & $<10^{-3}$ & -1.36 & {$[-2.05 ;-0.58]$} & 0.003 & -1.88 & {$[-3.38 ;-0.34]$} & 0.007 \\
\hline & NAt & & NS & & & NS & & & NS & \\
\hline & Eur & -1.01 & {$[-1.99 ;-0.42]$} & 0.007 & -1.34 & {$[-2.41 ;-0.38]$} & 0.01 & -1.80 & {$[-2.99 ;-0.50]$} & 0.017 \\
\hline & WMed & & NS & & & NS & & & NS & \\
\hline & MidE & & NS & & & NS & & & NS & \\
\hline & $\mathrm{Sib}$ & & NS & & & NS & & & NS & \\
\hline & NEAs & & NS & & & NS & & & NS & \\
\hline \multirow[t]{7}{*}{ SON } & EUS & & NS & & & NS & & & NS & \\
\hline & NAt & & NS & & & NS & & & NS & \\
\hline & Eur & & NS & & -1.14 & {$[-1.96 ;-0.07]$} & 0.023 & & NS & \\
\hline & WMed & & NS & & -1.23 & {$[-3.85 ;-0.17]$} & 0.04 & -1.29 & {$[-5.70 ;-0.40]$} & 0.018 \\
\hline & MidE & & NS & & & NS & & & NS & \\
\hline & $\mathrm{Sib}$ & & NS & & & NS & & & NS & \\
\hline & NEAs & & NS & & & NS & & & NS & \\
\hline
\end{tabular}


Table D7. CO relative trends in $\% \mathrm{yr}^{-1}$ during all the year in the UT. From left to right, the anomalies are taken from deseasonalized P05, monthly means, and P95. The insignificant trends with respect to the $95 \%$ confidence level are indicated as NS.

\begin{tabular}{|c|c|c|c|c|c|c|c|c|c|c|}
\hline \multirow{2}{*}{$\begin{array}{l}\text { Season } \\
\left(\% \mathrm{yr}^{-1}\right)\end{array}$} & \multirow[t]{2}{*}{ Region } & \multicolumn{3}{|c|}{ P05 } & \multicolumn{3}{|c|}{ Mean } & \multicolumn{3}{|c|}{ P95 } \\
\hline & & Slope & Conf. int. (95\%) & $p$ value & Slope & Conf. int. (95\%) & $p$ value & Slope & Conf. int. (95\%) & $p$ value \\
\hline \multirow[t]{7}{*}{ ANN } & EUS & -1.74 & {$[-2.43 ;-0.95]$} & $<10^{-3}$ & -1.49 & {$[-2.02 ;-0.95]$} & $<10^{-3}$ & -1.63 & {$[-2.15 ;-0.85]$} & $<10^{-3}$ \\
\hline & NAt & -1.21 & {$[-2.19 ;-0.55]$} & 0.003 & -1.38 & {$[-1.98 ;-0.69]$} & $<10^{-3}$ & -1.47 & {$[-2.14 ;-0.65]$} & $<10^{-3}$ \\
\hline & Eur & -1.39 & {$[-2.09 ;-0.81]$} & $<10^{-3}$ & -1.41 & {$[-1.96 ;-0.90]$} & $<10^{-3}$ & -1.54 & {$[-2.01 ;-1.04]$} & $<10^{-3}$ \\
\hline & WMed & -1.15 & {$[-2.50 ;-0.38]$} & 0.003 & -0.82 & {$[-2.10 ;-0.14]$} & 0.013 & & NS & \\
\hline & MidE & -0.80 & {$[-1.58 ;-0.09]$} & 0.027 & & NS & & & NS & \\
\hline & $\mathrm{Sib}$ & -0.99 & {$[-1.74 ;-0.30]$} & 0.007 & -1.31 & {$[-2.05 ;-0.30]$} & 0.01 & -1.21 & {$[-2.31 ;-0.15]$} & 0.02 \\
\hline & NEAs & -1.52 & {$[-2.53 ;-0.70]$} & $<10^{-3}$ & -1.89 & {$[-2.87 ;-0.71]$} & 0.003 & -2.04 & {$[-3.61 ;-0.73]$} & 0.003 \\
\hline
\end{tabular}

Table D8. CO relative trends in $\% \mathrm{yr}^{-1}$ during each season in the UT. From left to right, the anomalies are taken from deseasonalized P05, monthly means, and P95. The insignificant trends with respect to the $95 \%$ confidence level are indicated as NS. Note that the trends in northwest America are available only in DJF.

\begin{tabular}{|c|c|c|c|c|c|c|c|c|c|c|}
\hline \multirow{2}{*}{$\begin{array}{l}\text { Season } \\
\left(\% \mathrm{yr}^{-1}\right)\end{array}$} & \multirow[t]{2}{*}{ Region } & \multicolumn{3}{|c|}{ P05 } & \multicolumn{3}{|c|}{ Mean } & \multicolumn{3}{|c|}{ P95 } \\
\hline & & Slope & Conf. int. (95\%) & $p$ value & Slope & Conf. int. (95\%) & $p$ value & Slope & Conf. int. (95\%) & $p$ value \\
\hline \multirow[t]{8}{*}{ DJF } & WNAm & & NS & & -2.23 & {$[-3.73 ;-0.94]$} & 0.02 & -2.29 & {$[-4.34 ;-0.78]$} & 0.003 \\
\hline & EUS & & NS & & -1.51 & {$[-3.04 ;-0.63]$} & $<10^{-3}$ & -1.86 & {$[-2.63 ;-1.09]$} & $<10^{-3}$ \\
\hline & NAt & & NS & & -1.65 & {$[-3.19 ;-0.75]$} & 0.007 & -2.20 & {$[-3.45 ;-1.20]$} & 0.005 \\
\hline & Eur & -1.59 & {$[-2.98 ;-0.47]$} & 0.01 & -1.49 & {$[-2.77 ;-0.67]$} & 0.007 & -1.75 & {$[-2.88 ;-0.97]$} & 0.007 \\
\hline & WMed & & NS & & & NS & & & NS & \\
\hline & MidE & & NS & & -1.25 & {$[-3.99 ;-0.07]$} & 0.05 & & NS & \\
\hline & Sib & -1.17 & {$[-2.64 ;-0.18]$} & 0.035 & -1.67 & {$[-2.44 ;-0.33]$} & 0.023 & -1.11 & {$[-2.51 ;-0.30]$} & 0.025 \\
\hline & NEAs & -3.14 & {$[-4.15 ;-1.94]$} & $<10^{-3}$ & -2.56 & {$[-4.31 ;-0.65]$} & 0.01 & & NS & \\
\hline \multirow[t]{7}{*}{ MAM } & EUS & -2.43 & {$[-3.84 ;-1.27]$} & $<10^{-3}$ & -2.05 & {$[-3.01 ;-1.41]$} & $<10^{-3}$ & -2.05 & {$[-2.97 ;-0.76]$} & 0.017 \\
\hline & NAt & -2.32 & {$[-4.70 ;-0.97]$} & 0.013 & -1.97 & {$[-3.24 ;-1.16]$} & 0.003 & & NS & \\
\hline & Eur & -1.53 & {$[-3.10 ;-0.33]$} & 0.017 & -1.49 & {$[-3.03 ;-1.12]$} & 0.003 & -1.65 & {$[-3.00 ;-1.23]$} & 0.003 \\
\hline & WMed & & NS & & & NS & & & NS & \\
\hline & MidE & & NS & & & NS & & & NS & \\
\hline & Sib & & NS & & & NS & & & NS & \\
\hline & NEAs & -1.93 & {$[-3.19 ;-0.02]$} & 0.05 & -2.95 & {$[-4.91 ;-0.46]$} & 0.03 & & NS & \\
\hline \multirow[t]{7}{*}{ JJA } & EUS & -1.76 & {$[-2.64 ;-1.07]$} & $<10^{-3}$ & -1.32 & {$[-1.99 ;-0.56]$} & 0.003 & -1.45 & {$[-2.6 ;-0.26]$} & 0.007 \\
\hline & NAt & & NS & & & NS & & & NS & \\
\hline & Eur & -1.30 & {$[-2.55 ;-0.54]$} & 0.007 & -1.34 & {$[-2.41 ;-0.38]$} & 0.01 & -1.46 & {$[-2.43 ;-0.41]$} & 0.017 \\
\hline & WMed & & NS & & & NS & & & NS & \\
\hline & MidE & & NS & & & NS & & & NS & \\
\hline & Sib & & NS & & & NS & & & NS & \\
\hline & NEAs & & NS & & & NS & & & NS & \\
\hline \multirow[t]{7}{*}{ SON } & EUS & & NS & & & NS & & & NS & \\
\hline & NAt & & NS & & & NS & & & NS & \\
\hline & Eur & & NS & & -1.14 & {$[-1.96 ;-0.07]$} & 0.023 & & NS & \\
\hline & WMed & & NS & & -1.26 & {$[-3.93 ;-0.17]$} & 0.04 & -1.09 & {$[-4.83 ;-0.34]$} & 0.018 \\
\hline & MidE & & NS & & & NS & & & NS & \\
\hline & $\mathrm{Sib}$ & & NS & & & NS & & & NS & \\
\hline & NEAs & & NS & & & NS & & & NS & \\
\hline
\end{tabular}


Competing interests. The authors declare that they have no conflict of interest.

Special issue statement. This article is part of the special issue "Quadrennial Ozone Symposium 2016 - Status and trends of atmospheric ozone (ACP/AMT inter-journal SI)". It is a result of the Quadrennial Ozone Symposium 2016, Edinburgh, United Kingdom, 4-9 September 2016.

Acknowledgements. The authors acknowledge the strong support of the European Commission, Airbus, and the airlines (Lufthansa, Air-France, Austrian, Air Namibia, Cathay Pacific, Iberia, and China Airlines so far) who carry the MOZAIC or IAGOS equipment and have performed the maintenance since 1994. In its last 10 years of operation, MOZAIC has been funded by INSU-CNRS (France), Météo-France, Université Paul Sabatier (Toulouse, France), and Research Center Jülich (FZJ, Jülich, Germany). IAGOS has been additionally funded by the EU projects IAGOS-DS and IAGOS-ERI. We also wish to acknowledge our colleagues from the IAGOS team in FZJ, Jülich, for useful discussions. The MOZAIC-IAGOS database is supported by AERIS (CNES and INSU-CNRS). Data are also available via the AERIS website (www.aeris-data.fr). The authors also thank the Midi-Pyrénées region and Météo-France for funding Yann Cohen's PhD.

Edited by: Sophie Godin-Beekmann

Reviewed by: two anonymous referees

\section{References}

AERIS: Ozone and carbon monoxide data sets, available at: https: //www.aeris-data.fr/, last access: 11 April, 2018.

Andela, N., Kaiser, J., Heil, A., van Leeuwen, T. T., Wooster, M. J., van der Werf, G. R., Remy, S., and Schultz, M. G.: Assessment of the Global Fire Assimilation System (GFASv1), 702, 72 pp., 2013.

Angelbratt, J., Mellqvist, J., Simpson, D., Jonson, J. E., Blumenstock, T., Borsdorff, T., Duchatelet, P., Forster, F., Hase, F., Mahieu, E., De Mazière, M., Notholt, J., Petersen, A. K., Raffalski, U., Servais, C., Sussmann, R., Warneke, T., and Vigouroux, C.: Carbon monoxide $(\mathrm{CO})$ and ethane $\left(\mathrm{C}_{2} \mathrm{H}_{6}\right)$ trends from ground-based solar FTIR measurements at six European stations, comparison and sensitivity analysis with the EMEP model, Atmos. Chem. Phys., 11, 9253-9269, https://doi.org/10.5194/acp11-9253-2011, 2011.

Barret, B., Sauvage, B., Bennouna, Y., and Le Flochmoen, E.: Upper-tropospheric $\mathrm{CO}$ and $\mathrm{O}_{3}$ budget during the Asian summer monsoon, Atmos. Chem. Phys., 16, 9129-9147, https://doi.org/10.5194/acp-16-9129-2016, 2016.

Boothe, A. C. and Homeyer, C. R.: Global large-scale stratospheretroposphere exchange in modern reanalyses, Atmos. Chem. Phys., 17, 5537-5559, https://doi.org/10.5194/acp-17-55372017, 2017.

Bremer, H., Kar, J., Drummond, J. R., Nichitu, F., Zou, J., Liu, J., Gille, J. C., Deeter, M. N., Francis, G., Ziskin, D., and Warner, J.: Spatial and temporal variation of MOPITT CO in
Africa and South America: A comparison with SHADOZ ozone and MODIS aerosol, J. Geophys. Res.-Atmos., 109, 2156-2202, https://doi.org/10.1029/2003JD004234, 2004.

Butchart, N.: The Brewer-Dobson circulation, Rev. Geophys., 52, 157-184, https://doi.org/10.1002/2013RG000448, 2014.

Cammas, J.-P., Brioude, J., Chaboureau, J.-P., Duron, J., Mari, C., Mascart, P., Nédélec, P., Smit, H., Pätz, H.-W., Volz-Thomas, A., Stohl, A., and Fromm, M.: Injection in the lower stratosphere of biomass fire emissions followed by long-range transport: a MOZAIC case study, Atmos. Chem. Phys., 9, 5829-5846, https://doi.org/10.5194/acp-9-5829-2009, 2009

Carslaw, D. C. and Ropkins, K.: openair - An R package for air quality data analysis, Environ. Modell. Softw., 27-28, 52-61, https://doi.org/10.1016/j.envsoft.2011.09.008, 2012.

Clark, H., Sauvage, B., Thouret, V., Nédélec, P., Blot, R., Wang, K.-Y., Smit, H., Neis, P., Petzold, A., Athier, G., Boulanger, D., Cousin, J.-M., Beswick, K., Gallagher, M., Baumgardner, D., Kaiser, J., Flaud, J.-M., Wahner, A., Volz-Thomas, A., and Cammas, J.-P.: The first regular measurements of ozone, carbon monoxide and water vapour in the Pacific UTLS by IAGOS, Tellus B, 67, 1600-0889, https://doi.org/10.3402/tellusb.v67.28385, 2015.

Cooper, O., Parrish, D., Ziemke, J., Balashov, N., Cupeiro, M., Galbally, I., Gilge, S., Horowitz, L., Jensen, N., Lamarque, J., Naik, V., Oltmans, S. J., Schwab, J., Shindell, D. T., Thompson, A. M., Thouret, V., Wang, Y., and Zbinden, R. M.: Global distribution and trends of tropospheric ozone: An observation-based review, Elem. Sci. Anth., 2, https://doi.org/10.12952/journal.elementa.000029, 2014.

Cooper, O. R., Trainer, M., Thompson, A. M., Oltmans, S. J., Tarasick, D. W., Witte, J. C., Stohl, A., Eckhardt, S., Lelieveld, J., Newchurch, M. J., Johnson, B. J., Portmann, R. W., Kalnajs, L., Dubey, M. K., Leblanc, T., McDermid, I. S., Forbes, G., Wolfe, D., Carey-Smith, T., Morris, G. A., Lefer, B., Rappenglück, B., Joseph, E., Schmidlin, F., Meagher, J., Fehsenfeld, F. C., Keating, T. J., Van Curen, R. A., and Minschwaner, K.: Evidence for a recurring eastern North America upper tropospheric ozone maximum during summer, J. Geophys. Res.-Atmos., 112, d23304, https://doi.org/10.1029/2007JD008710, 2007.

Cooper, O. R., Eckhardt, S., Crawford, J. H., Brown, C. C., Cohen, R. C., Bertram, T. H., Wooldridge, P., Perring, A., Brune, W. H., Ren, X., Brunner, D., and Baughcum, S. L.: Summertime buildup and decay of lightning $\mathrm{NO}_{x}$ and aged thunderstorm outflow above North America, J. Geophys. Res.-Atmos., 114, d01101, https://doi.org/10.1029/2008JD010293, 2009.

Cooper, O. R., Parrish, D. D., Stohl, A., Trainer, M., Nédélec, P., Thouret, V., Cammas, J.-P., Oltmans, S. J., Johnson, B. J., Tarasick, D. W., Leblanc, T., McDermid, I. S., Jaffe, D., Gao, R., Stith, J., Ryerson, T., Aikin, K., Campos, T., Weinheimer, A., and Avery, M. A.: Increasing springtime ozone mixing ratios in the free troposphere over western North America, Nat. Geosci., 463, 344-348, https://doi.org/10.1038/nature08708, 2010.

Ebojie, F., von Savigny, C., Ladstätter-Weißenmayer, A., Rozanov, A., Weber, M., Eichmann, K.-U., Bötel, S., Rahpoe, N., Bovensmann, H., and Burrows, J. P.: Tropospheric column amount of ozone retrieved from SCIAMACHY limb-nadirmatching observations, Atmos. Meas. Tech., 7, 2073-2096, https://doi.org/10.5194/amt-7-2073-2014, 2014. 
Ebojie, F., Burrows, J. P., Gebhardt, C., Ladstätter-Weißenmayer, A., von Savigny, C., Rozanov, A., Weber, M., and Bovensmann, H.: Global tropospheric ozone variations from 2003 to 2011 as seen by SCIAMACHY, Atmos. Chem. Phys., 16, 417-436, https://doi.org/10.5194/acp-16-417-2016, 2016.

Edwards, D. P., Emmons, L. K., Hauglustaine, D. A., Chu, D. A., Gille, J. C., Kaufman, Y. J., Pétron, G., Yurganov, L. N., Giglio, L., Deeter, M. N., Yudin, V., Ziskin, D. C., Warner, J., Lamarque, J.-F., Francis, G. L., Ho, S. P., Mao, D., Chen, J., Grechko, E. I., and Drummond, J. R.: Observations of carbon monoxide and aerosols from the Terra satellite: Northern Hemisphere variability, J. Geophys. Res.-Atmos., 109, 2156-2202, https://doi.org/10.1029/2004JD004727, 2004.

Elguindi, N., Clark, H., Ordóñez, C., Thouret, V., Flemming, J., Stein, O., Huijnen, V., Moinat, P., Inness, A., Peuch, V.H., Stohl, A., Turquety, S., Athier, G., Cammas, J.-P., and Schultz, M.: Current status of the ability of the GEMS/MACC models to reproduce the tropospheric $\mathrm{CO}$ vertical distribution as measured by MOZAIC, Geosci. Model Dev., 3, 501-518, https://doi.org/10.5194/gmd-3-501-2010, 2010.

Garfinkel, C. I., Aquila, V., Waugh, D. W., and Oman, L. D.: Time-varying changes in the simulated structure of the BrewerDobson Circulation, Atmos. Chem. Phys., 17, 1313-1327, https://doi.org/10.5194/acp-17-1313-2017, 2017.

Gaudel, A. and Cooper, O. R.: Tropospheric Ozone Assessment Report: Present-day distribution and trends of tropospheric ozone relevant to climate and global atmospheric chemistry model evaluation, Elem. Sci. Anth., in press, 2018.

Gaudel, A., Ancellet, G., and Godin-Beekmann, S.: Analysis of 20 years of tropospheric ozone vertical profiles by lidar and ECC at Observatoire de Haute Provence $(\mathrm{OHP})$ at $44^{\circ} \mathrm{N}, 6.7^{\circ} \mathrm{E}$, Atmos. Environ., 113, 78-89, https://doi.org/10.1016/j.atmosenv.2015.04.028, 2015a.

Gaudel, A., Clark, H., Thouret, V., Jones, L., Inness, A., Flemming, J., Stein, O., Huijnen, V., Eskes, H., Nédélec, P., and Boulanger, D.: On the use of MOZAIC-IAGOS data to assess the ability of the MACC reanalysis to reproduce the distribution of ozone and CO in the UTLS over Europe, Tellus B, 67, 27955, https://doi.org/10.3402/tellusb.v67.27955, 2015b.

Gettelman, A., Hegglin, M. I., Son, S.-W., Kim, J., Fujiwara, M., Birner, T., Kremser, S., Rex, M., Añel, J. A., Akiyoshi, H., Austin, J., Bekki, S., Braesike, P., Brühl, C., Butchart, N., Chipperfield, M., Dameris, M., Dhomse, S., Garny, H., Hardiman, S. C., Jöckel, P., Kinnison, D. E., Lamarque, J. F., Mancini, E., Marchand, M., Michou, M., Morgenstern, O., Pawson, S., Pitari, G., Plummer, D., Pyle, J. A., Rozanov, E., Scinocca, J., Shepherd, T. G., Shibata, K., Smale, D., Teyssèdre, H., and Tian, W.: Multimodel assessment of the upper troposphere and lower stratosphere: Tropics and global trends, J. Geophys. Res.-Atmos., 115, d00M08, https://doi.org/10.1029/2009JD013638, 2010.

Gettelman, A., Hoor, P., Pan, L. L., Randel, W. J., Hegglin, M. I., and Birner, T.: The extratropical upper troposphere and lower stratosphere, Rev. Geophys., 49, rG3003, https://doi.org/10.1029/2011RG000355, 2011.

Granados-Muñoz, M. J., Johnson, M. S., and Leblanc, T.: Influence of the North American monsoon on Southern California tropospheric ozone levels during summer in 2013 and 2014, Geophys. Res. Lett., 44, 6431-6439, https://doi.org/10.1002/2017GL073375 2017.
Granados-Muñoz, M. J. and Leblanc, T.: Tropospheric ozone seasonal and long-term variability as seen by lidar and surface measurements at the JPL-Table Mountain Facility, California, Atmos. Chem. Phys., 16, 9299-9319, https://doi.org/10.5194/acp16-9299-2016, 2016.

Granier, C., Bessagnet, B., Bond, T., D’Angiola, A., van der Gon, H., Frost, G. J., Heil, A., Kaiser, J. W., Kinne, S., Klimont, Z., Kloster, S., Lamarque, J.-F., Liousse, C., Masui, T., Meleux, F., Mieville, A., Ohara, T., Raut, J.-C., Riahi, K., Schultz, M. G., Smith, S. J., Thompson, A., van Aardenne, J., van der Werf, G. R., and van Vuuren, D. P.: Evolution of anthropogenic and biomass burning emissions of air pollutants at global and regional scales during the 1980-2010 period, Clim. Change, 109, 163, https://doi.org/10.1007/s10584-011-0154-1, 2011.

Gratz, L., Jaffe, D., and Hee, J.: Causes of increasing ozone and decreasing carbon monoxide in springtime at the Mt. Bachelor Observatory from 2004 to 2013, Atmos. Environ., 109, 323-330, https://doi.org/10.1016/j.atmosenv.2014.05.076, 2015.

Gressent, A., Sauvage, B., Defer, E., Pätz, H. W., Thomas, K., Holle, R., Cammas, J.-P., Nédélec, P., Boulanger, D., Thouret, V., and Volz-Thomas, A.: Lightning $\mathrm{NO}_{x}$ influence on large-scale $\mathrm{NO}_{y}$ and $\mathrm{O}_{3}$ plumes observed over the northern mid-latitudes, Tellus B, 66, 25544, https://doi.org/10.3402/tellusb.v66.25544, 2014.

Helten, M., Smit, H. G. J., Sträter, W., Kley, D., Nédélec, P., Zöger, M., and Busen, R.: Calibration and performance of automatic compact instrumentation for the measurement of relative humidity from passenger aircraft, J. Geophys. Res.-Atmos., 103, 25643-25652, https://doi.org/10.1029/98JD00536, 1998.

Hsu, J. and Prather, M. J.: Stratospheric variability and tropospheric ozone, J. Geophys. Res.-Atmos., 114, d06102, https://doi.org/10.1029/2008JD010942, 2009.

Huang, L., Jiang, J. H., Murray, L. T., Damon, M. R., Su, H., and Livesey, N. J.: Evaluation of UTLS carbon monoxide simulations in GMI and GEOS-Chem chemical transport models using Aura MLS observations, Atmos. Chem. Phys., 16, 5641-5663, https://doi.org/10.5194/acp-16-5641-2016, 2016.

Hudman, R. C., Jacob, D. J., Cooper, O. R., Evans, M. J., Heald, C. L., Park, R. J., Fehsenfeld, F., Flocke, F., Holloway, J., Hübler, G., Kita, K., Koike, M., Kondo, Y., Neuman, A., Nowak, J., Oltmans, S., Parrish, D., Roberts, J. M., and Ryerson, T.: Ozone production in transpacific Asian pollution plumes and implications for ozone air quality in California, J. Geophys. Res.-Atmos., 109, d23S10, https://doi.org/10.1029/2004JD004974, 2004.

IAGOS: Ozone and carbon monoxide data sets, available at: http: //www.iagos.org/, last access: 11 April, 2018.

IPCC: Climate change 2013: The physical science basis, Tech. rep., available at: http://www.ipcc.ch/report/ar5/wg1/ (last access: 11 April 2018), 2013.

Jiang, J. H., Livesey, N. J., Su, H., Neary, L., McConnell, J. C., and Richards, N. A. D.: Connecting surface emissions, convective uplifting, and long-range transport of carbon monoxide in the upper troposphere: New observations from the Aura Microwave Limb Sounder, Geophys. Res. Lett., 34, 118812, https://doi.org/10.1029/2007GL030638, 2007.

Jiang, Z., Worden, J. R., Worden, H., Deeter, M., Jones, D. B. A., Arellano, A. F., and Henze, D. K.: A 15-year record of CO emissions constrained by MOPITT CO observations, Atmos. 
Chem. Phys., 17, 4565-4583, https://doi.org/10.5194/acp-174565-2017, 2017.

Kaiser, J. W., Heil, A., Andreae, M. O., Benedetti, A., Chubarova, N., Jones, L., Morcrette, J.-J., Razinger, M., Schultz, M. G., Suttie, M., and van der Werf, G. R.: Biomass burning emissions estimated with a global fire assimilation system based on observed fire radiative power, Biogeosciences, 9, 527-554, https://doi.org/10.5194/bg-9-527-2012, 2012.

Koumoutsaris, S., Bey, I., Generoso, S., and Thouret, V.: Influence of El Niño-Southern Oscillation on the interannual variability of tropospheric ozone in the northern midlatitudes, J. Geophys. Res.-Atmos., 113, d19301, https://doi.org/10.1029/2007JD009753, 2008.

Laat, A. T. J. D., Gloudemans, A. M. S., Aben, I., and Schrijver, H.: Global evaluation of SCIAMACHY and MOPITT carbon monoxide column differences for 2004-2005, J. Geophys. Res.Atmos., 115, D06307, https://doi.org/10.1029/2009JD012698, 2010.

Laken, B. A. and Shahbaz, T.: Satellite-Detected Carbon Monoxide Pollution during 2000-2012: Examining Global Trends and also Regional Anthropogenic Periods over China, the EU and the USA, Climate, 2, 1-16, https://doi.org/10.3390/cli2010001, 2014.

Lelieveld, J., Gromov, S., Pozzer, A., and Taraborrelli, D.: Global tropospheric hydroxyl distribution, budget and reactivity, Atmos. Chem. Phys., 16, 12477-12493, https://doi.org/10.5194/acp-1612477-2016, 2016.

Lin, M., Fiore, A. M., Horowitz, L. W., Langford, A. O., Oltmans, S. J., Tarasick, D., and Rieder, H. E.: Climate variability modulates western US ozone air quality in spring via deep stratospheric intrusions, Nat. Commun., 6, 7105, https://doi.org/10.1038/ncomms8105, 2015.

Liu, J., Logan, J. A., Jones, D. B. A., Livesey, N. J., Megretskaia, I., Carouge, C., and Nedelec, P.: Analysis of CO in the tropical troposphere using Aura satellite data and the GEOS-Chem model: insights into transport characteristics of the GEOS meteorological products, Atmos. Chem. Phys., 10, 12207-12232, https://doi.org/10.5194/acp-10-12207-2010, 2010.

Livesey, N. J., Logan, J. A., Santee, M. L., Waters, J. W., Doherty, R. M., Read, W. G., Froidevaux, L., and Jiang, J. H.: Interrelated variations of $\mathrm{O}_{3}, \mathrm{CO}$ and deep convection in the tropical/subtropical upper troposphere observed by the Aura Microwave Limb Sounder (MLS) during 2004-2011, Atmos. Chem. Phys., 13, 579-598, https://doi.org/10.5194/acp-13-5792013, 2013.

Logan, J. A., Prather, M. J., Wofsy, S. C., and McElroy, M. B.: Tropospheric chemistry: A global perspective, J. Geophys. Res.-Oceans, 86, 7210-7254, https://doi.org/10.1029/JC086iC08p07210, 1981.

Logan, J. A., Staehelin, J., Megretskaia, I. A., Cammas, J.P., Thouret, V., Claude, H., De Backer, H., Steinbacher, M., Scheel, H.-E., Stübi, R., Fröhlich, M., and Derwent, R.: Changes in ozone over Europe: Analysis of ozone measurements from sondes, regular aircraft (MOZAIC) and alpine surface sites, J. Geophys. Res.-Atmos., 117, D09301, https://doi.org/10.1029/2011JD016952, 2012.

Madonna, E., Wernli, H., Joos, H., and Martius, O.: Warm Conveyor Belts in the ERA-Interim Dataset (1979-2010). Part I: Cli- matology and Potential Vorticity Evolution, J. Climate, 27, 3-26, https://doi.org/10.1175/JCLI-D-12-00720.1, 2014.

Marenco, A., Thouret, V., Nédélec, P., Smit, H., Helten, M., Kley, D., Karsher, F., Simon, P., Law, K., Pyle, J., Poschmann, G., Von Wrede, R., Hume, C., and Cook, T.: Measurement of ozone and water vapour by Airbus in-service aircraft: The MOZAIC airborne programme, an overview, J. Geophys. Res., 103, 2563125642, https://doi.org/10.1029/98JD00977, 1998.

Monks, P. S., Archibald, A. T., Colette, A., Cooper, O., Coyle, M., Derwent, R., Fowler, D., Granier, C., Law, K. S., Mills, G. E., Stevenson, D. S., Tarasova, O., Thouret, V., von Schneidemesser, E., Sommariva, R., Wild, O., and Williams, M. L.: Tropospheric ozone and its precursors from the urban to the global scale from air quality to short-lived climate forcer, Atmos. Chem. Phys., 15, 8889-8973, https://doi.org/10.5194/acp-15-8889-2015, 2015.

Nédélec, P., Cammas, J.-P., Thouret, V., Athier, G., and Cousin, J.M.: An improved infrared carbon monoxide analyser for routine measurements aboard commercial Airbus aircraft: technical validation and first scientific results of the MOZAIC III programme, Atmos. Chem. Phys., 3, 1551-1564, https://doi.org/10.5194/acp3-1551-2003, 2003

Nédélec, P., Thouret, V., Brioude, J., Sauvage, B., Cammas, J.P., and Stohl, A.: Extreme $\mathrm{CO}$ concentrations in the upper troposphere over northeast Asia in June 2003 from the in situ MOZAIC aircraft data, Geophys. Res. Lett., 32, 114807, https://doi.org/10.1029/2005GL023141, 2005.

Nédélec, P., Blot, R., Boulanger, D., Athier, G., Cousin, J.-M., Gautron, B., Petzold, A., Volz-Thomas, A., and Thouret, V.: Instrumentation on commercial aircraft for monitoring the atmospheric composition on a global scale: the IAGOS system, technical overview of ozone and carbon monoxide measurements, Tellus B, 67, 27791, https://doi.org/10.3402/tellusb.v67.27791, 2015.

Neu, J. L., Flury, T., Manney, G. L., Santee, M. L., Livesey, N. J., and Worden, J.: Tropospheric ozone variations governed by changes in stratospheric circulation, Nat. Geosci., 7, 340-344, https://doi.org/10.1038/ngeo2138, 2014a.

Neu, J. L., Hegglin, M. I., Tegtmeier, S., Bourassa, A., Degenstein, D., Froidevaux, L., Fuller, R., Funke, B., Gille, J., Jones, A., Rozanov, A., Toohey, M., von Clarmann, T., Walker, K. A., and Worden, J. R.: The SPARC Data Initiative: Comparison of upper troposphere/lower stratosphere ozone climatologies from limbviewing instruments and the nadir-viewing Tropospheric Emission Spectrometer, J. Geophys. Res.-Atmos., 119, 6971-6990, https://doi.org/10.1002/2013JD020822, 2013JD020822, 2014b.

Olsen, M. A., Schoeberl, M. R., and Douglass, A. R.: Stratospheretroposphere exchange of mass and ozone, J. Geophys. Res. Atmos., 109, D24114, https://doi.org/10.1029/2004JD005186, 2004.

Olsen, M. A., Douglass, A. R., and Kaplan, T. B.: Variability of extratropical ozone stratosphere-troposphere exchange using microwave limb sounder observations, J. Geophys. Res.-Atmos., 118, 1090-1099, https://doi.org/10.1029/2012JD018465, 2013.

Oltmans, S., Lefohn, A., Shadwick, D., Harris, J., Scheel, H., Galbally, I., Tarasick, D., Johnson, B., Brunke, E.-G., Claude, H., Zeng, G., Nichol, S., Schmidlin, F., Davies, J., Cuevas, E., Redondas, A., Naoe, H., Nakano, T., and Kawasato, T.: Recent tropospheric ozone changes - A pattern domi- 
nated by slow or no growth, Atmos. Environ., 67, 331-351, https://doi.org/10.1016/j.atmosenv.2012.10.057, 2013.

Osman, M. K., Tarasick, D. W., Liu, J., Moeini, O., Thouret, V., Fioletov, V. E., Parrington, M., and Nédélec, P.: Carbon monoxide climatology derived from the trajectory mapping of global MOZAIC-IAGOS data, Atmos. Chem. Phys., 16, 10263-10282, https://doi.org/10.5194/acp-16-10263-2016, 2016.

Park, M., Randel, W. J., Gettelman, A., Massie, S. T., and Jiang, J. H.: Transport above the Asian summer monsoon anticyclone inferred from Aura Microwave Limb Sounder tracers, J. Geophys. Res.-Atmos., 112, d16309, https://doi.org/10.1029/2006JD008294, 2007.

Park, M., Randel, W. J., Emmons, L. K., and Livesey, N. J.: Transport pathways of carbon monoxide in the Asian summer monsoon diagnosed from Model of Ozone and Related Tracers (MOZART), J. Geophys. Res.-Atmos., 114, d08303, https://doi.org/10.1029/2008JD010621, 2009.

Petetin, H., Thouret, V., Fontaine, A., Sauvage, B., Athier, G., Blot, R., Boulanger, D., Cousin, J.-M., and Nédélec, P.: Characterizing tropospheric ozone and CO around Frankfurt between 19942012 based on MOZAIC-IAGOS aircraft measurements, Atmos. Chem. Phys., 16, 15147-15163, https://doi.org/10.5194/acp-1615147-2016, 2016.

Petzold, A., Thouret, V., Gerbig, C., Zahn, A., Brenninkmeijer, C., Gallagher, M., Hermann, M., Pontaud, M., Ziereis, H., Boulanger, D., Marshall, J., Nédélec, P., Smit, H., Friess, U., Flaud, J.-M., Wahner, A., Cammas, J.-P., and Volz-Thomas, A.: Global-scale atmosphere monitoring by in-service aircraft - current achievements and future prospects of the European Research Infrastructure IAGOS, Tellus B, 67, 28452, https://doi.org/10.3402/tellusb.v67.28452, 2015.

Randel, W. J., Seidel, D. J., and Pan, L. L.: Observational characteristics of double tropopauses, J. Geophys. Res.-Atmos., 112, d07309, https://doi.org/10.1029/2006JD007904, 2007.

Ricaud, P., Sič, B., El Amraoui, L., Attié, J.-L., Zbinden, R., Huszar, P., Szopa, S., Parmentier, J., Jaidan, N., Michou, M., Abida, R., Carminati, F., Hauglustaine, D., August, T., Warner, J., Imasu, R., Saitoh, N., and Peuch, V.-H.: Impact of the Asian monsoon anticyclone on the variability of mid-to-upper tropospheric methane above the Mediterranean Basin, Atmos. Chem. Phys., 14, 1142711446, https://doi.org/10.5194/acp-14-11427-2014, 2014.

Riese, M., Ploeger, F., Rap, A., Vogel, B., Konopka, P., Dameris, M., and Forster, P.: Impact of uncertainties in atmospheric mixing on simulated UTLS composition and related radiative effects, J. Geophys. Res., 117, D16305, https://doi.org/10.1029/2012JD017751, 2012.

Sauvage, B., Thouret, V., Cammas, J.-P., Gheusi, F., Athier, G., and Nédélec, P.: Tropospheric ozone over Equatorial Africa: regional aspects from the MOZAIC data, Atmos. Chem. Phys., 5, 311335, https://doi.org/10.5194/acp-5-311-2005, 2005.

Sauvage, B., Martin, R. V., van Donkelaar, A., Liu, X., Chance, K., Jaeglé, L., Palmer, P. I., Wu, S., and Fu, T.-M.: Remote sensed and in situ constraints on processes affecting tropical tropospheric ozone, Atmos. Chem. Phys., 7, 815-838, https://doi.org/10.5194/acp-7-815-2007, 2007a.

Sauvage, B., Martin, R. V., van Donkelaar, A., and Ziemke, J. R.: Quantification of the factors controlling tropical tropospheric ozone and the South Atlantic maximum, J. Geophys. Res.-
Atmos., 112, d11309, https://doi.org/10.1029/2006JD008008, 2007b.

Sauvage, B., Thouret, V., Cammas, J.-P., Brioude, J., Nédélec, P., and Mari, C.: Meridional ozone gradients in the African upper troposphere, Geophys. Res. Lett., 34, 103817, https://doi.org/10.1029/2006GL028542, 2007c.

Sauvage, B., Fontaine, A., Eckhardt, S., Auby, A., Boulanger, D., Petetin, H., Paugam, R., Athier, G., Cousin, J.-M., Darras, S., Nédélec, P., Stohl, A., Turquety, S., Cammas, J.-P., and Thouret, V.: Source attribution using FLEXPART and carbon monoxide emission inventories: SOFT-IO version 1.0, Atmos. Chem. Phys., 17, 15271-15292, https://doi.org/10.5194/acp-17-152712017, 2017.

Sen, P. K.: Estimates of the Regression Coefficient Based on Kendall's Tau, J. Am. Stat. Assoc., 63, 1379-1389, https://doi.org/10.1080/01621459.1968.10480934, 1968.

Stevenson, D. S., Young, P. J., Naik, V., Lamarque, J.-F., Shindell, D. T., Voulgarakis, A., Skeie, R. B., Dalsoren, S. B., Myhre, G., Berntsen, T. K., Folberth, G. A., Rumbold, S. T., Collins, W. J., MacKenzie, I. A., Doherty, R. M., Zeng, G., van Noije, T. P. C., Strunk, A., Bergmann, D., Cameron-Smith, P., Plummer, D. A., Strode, S. A., Horowitz, L., Lee, Y. H., Szopa, S., Sudo, K., Nagashima, T., Josse, B., Cionni, I., Righi, M., Eyring, V., Conley, A., Bowman, K. W., Wild, O., and Archibald, A.: Tropospheric ozone changes, radiative forcing and attribution to emissions in the Atmospheric Chemistry and Climate Model Intercomparison Project (ACCMIP), Atmos. Chem. Phys., 13, 3063-3085, https://doi.org/10.5194/acp-13-3063-2013, 2013.

Stratmann, G., Ziereis, H., Stock, P., Brenninkmeijer, C., Zahn, A., Rauthe-Schöch, A., Velthoven, P., Schlager, H., and Volz-Thomas, A.: $\{\mathrm{NO}\}$ and $\left\{\mathrm{NO}_{y}\right\}$ in the upper troposphere: Nine years of \{CARIBIC $\}$ measurements onboard a passenger aircraft, Atmos. Environ., 133, 93-111, https://doi.org/10.1016/j.atmosenv.2016.02.035, 2016.

Tang, Q., Hess, P. G., Brown-Steiner, B., and Kinnison, D. E.: Tropospheric ozone decrease due to the Mount Pinatubo eruption: Reduced stratospheric influx, Geophys. Res. Lett., 40, 55535558, https://doi.org/10.1002/2013GL056563, 2013.

Tanimoto, H., Okamoto, S., Thouret, V., Emmons, L. K., Tilmes, S., Lamarque, J.-F., and Gaubert, B.: Free tropospheric ozone trends over East Asia from 1991 to 2015, J. Geophys. Res.-Atmos., submitted, 2018.

Tereszchuk, K. A., Moore, D. P., Harrison, J. J., Boone, C. D., Park, M., Remedios, J. J., Randel, W. J., and Bernath, P. F.: Observations of peroxyacetyl nitrate (PAN) in the upper troposphere by the Atmospheric Chemistry Experiment-Fourier Transform Spectrometer (ACE-FTS), Atmos. Chem. Phys., 13, 5601-5613, https://doi.org/10.5194/acp-13-5601-2013, 2013.

Thompson, A. M., Witte, J. C., Oltmans, S. J., Schmidlin, F. J., Logan, J. A., Fujiwara, M., Kirchhoff, V. W. J. H., Posny, F., Coetzee, G. J. R., Hoegger, B., Kawakami, S., Ogawa, T., Fortuin, J. P. F., and Kelder, H. M.: Southern Hemisphere Additional Ozonesondes (SHADOZ) 1998-2000 tropical ozone climatology 2. Tropospheric variability and the zonal wave-one, J. Geophys. Res.-Atmos., 108, 8241, https://doi.org/10.1029/2002JD002241, 2003.

Thouret, V., Marenco, A., Logan, J. A., Nédélec, P., and Grouhel, C.: Comparisons of ozone measurements from the MOZAIC airborne program and the ozone sounding net- 
work at eight locations, J. Geophys. Res., 103, 25695-25720, https://doi.org/10.1029/98JD02243, 1998.

Thouret, V., Cammas, J.-P., Sauvage, B., Athier, G., Zbinden, R. M., Nédélec, P., Simon, P., and Karcher, F.: Tropopause referenced ozone climatology and inter-annual variability (1994-2003) from the MOZAIC programme, Atmos. Chem. Phys., 6, 1033-1051, https://doi.org/10.5194/acp-6-1033-2006, 2006.

Tilmes, S., Pan, L. L., Hoor, P., Atlas, E., Avery, M. A., Campos, T., Christensen, L. E., Diskin, G. S., Gao, R.-S., Herman, R. L., Hintsa, E. J., Loewenstein, M., Lopez, J., Paige, M. E., Pittman, J. V., Podolske, J. R., Proffitt, M. R., Sachse, G. W., Schiller, C., Schlager, H., Smith, J., Spelten, N., Webster, C., Weinheimer, A., and Zondlo, M. A.: An aircraft-based upper troposphere lower stratosphere $\mathrm{O}_{3}, \mathrm{CO}$, and $\mathrm{H}_{2} \mathrm{O}$ climatology for the Northern Hemisphere, J. Geophys. Res.-Atmos., 115, d14303, https://doi.org/10.1029/2009JD012731, 2010.

Tyrlis, E., Lelieveld, J., and Steil, B.: The summer circulation over the eastern Mediterranean and the Middle East: influence of the South Asian monsoon, Clim. Dynam., 40, 1103-1123, https://doi.org/10.1007/s00382-012-1528-4, 2013.

van der Werf, G. R., Randerson, J. T., Giglio, L., Collatz, G. J., Mu, M., Kasibhatla, P. S., Morton, D. C., DeFries, R. S., Jin, Y., and van Leeuwen, T. T.: Global fire emissions and the contribution of deforestation, savanna, forest, agricultural, and peat fires (1997-2009), Atmos. Chem. Phys., 10, 11707-11735, https://doi.org/10.5194/acp-10-11707-2010, 2010.

Verstraeten, W. W., Boersma, K. F., Zörner, J., Allaart, M. A. F., Bowman, K. W., and Worden, J. R.: Validation of six years of TES tropospheric ozone retrievals with ozonesonde measurements: implications for spatial patterns and temporal stability in the bias, Atmos. Meas. Tech., 6, 1413-1423, https://doi.org/10.5194/amt-6-1413-2013, 2013.

Škerlak, B., Sprenger, M., and Wernli, H.: A global climatology of stratosphere-troposphere exchange using the ERA-Interim data set from 1979 to 2011, Atmos. Chem. Phys., 14, 913-937, https://doi.org/10.5194/acp-14-913-2014, 2014.

Wespes, C., Hurtmans, D., Clerbaux, C., and Coheur, P.F.: $\mathrm{O}_{3}$ variability in the troposphere as observed by IASI over 2008-2016: Contribution of atmospheric chemistry and dynamics, J. Geophys. Res.-Atmos., 122, 2429-2451, https://doi.org/10.1002/2016JD025875, 2017.
Worden, H. M., Deeter, M. N., Frankenberg, C., George, M., Nichitiu, F., Worden, J., Aben, I., Bowman, K. W., Clerbaux, C., Coheur, P.-F., de Laat, A. T. J., Detweiler, R., Drummond, J. R., Edwards, D. P., Gille, J. C., Hurtmans, D., Luo, M., Martìnez-Alonso, S., Massie, S., Pfister, G., and Warner, J. X.: Decadal record of satellite carbon monoxide observations, Atmos. Chem. Phys., 13, 837-850, https://doi.org/10.5194/acp-13837-2013, 2013.

Yamasoe, M., Sauvage, B., Thouret, V., Nédélec, P., Le Flochmoen, E., and Barret, B.: Analysis of tropospheric ozone and carbon monoxide profiles over South America based on MOZAIC/IAGOS database and model simulations, Tellus B, 67, 27884, https://doi.org/10.3402/tellusb.v67.27884, 2015.

Zanis, P., Hadjinicolaou, P., Pozzer, A., Tyrlis, E., Dafka, S., Mihalopoulos, N., and Lelieveld, J.: Summertime free-tropospheric ozone pool over the eastern Mediterranean/Middle East, Atmos. Chem. Phys., 14, 115-132, https://doi.org/10.5194/acp-14-1152014, 2014.

Zbinden, R. M., Thouret, V., Ricaud, P., Carminati, F., Cammas, J.-P., and Nédélec, P.: Climatology of pure Tropospheric profiles and column contents of ozone and carbon monoxide using MOZAIC in the mid-northern latitudes $\left(24^{\circ} \mathrm{N}\right.$ to $\left.50^{\circ} \mathrm{N}\right)$ from 1994 to 2009, Atmos. Chem. Phys., 13, 12363-12388, https://doi.org/10.5194/acp-13-12363-2013, 2013.

Zhang, Y., Cooper, O. R., Gaudel, A., Thompson, A. M., Nédélec, P., Ogino, S.-Y., and West, J. J.: Tropospheric ozone change from 1980 to 2010 dominated by equatorward redistribution of emissions, Nat. Geosci., 9, 875-879, https://doi.org/10.1038/NGEO2827, 2016.

Ziemke, J. R., Chandra, S., Labow, G. J., Bhartia, P. K., Froidevaux, L., and Witte, J. C.: A global climatology of tropospheric and stratospheric ozone derived from Aura OMI and MLS measurements, Atmos. Chem. Phys., 11, 9237-9251, https://doi.org/10.5194/acp-11-9237-2011, 2011. 